\title{
Norway: 2017 Article IV Consultation- Press Release; and Staff Report
}




\section{INTERNATIONAL MONETARY FUND}

\section{NORWAY}

IMF Country Report No. 17/182

\section{ARTICLE IV CONSULTATION_PRESS RELEASE; AND STAFF REPORT}

Under Article IV of the IMF's Articles of Agreement, the IMF holds bilateral discussions with members, usually every year. In the context of the 2017 Article IV consultation with Norway, the following documents have been released and are included in this package:

- A Press Release.

- The Staff Report prepared by a staff team of the IMF for the Executive Board's consideration on a lapse of time basis, following discussions that ended on May 23, 2017 with the officials of Norway on economic developments and policies. Based on information available at the time of these discussions, the staff report was completed on June 15, 2017.

- An Informational Annex prepared by the IMF staff.

The document listed below have been or will be separately released.

Selected Issues

The IMF's transparency policy allows for the deletion of market-sensitive information and premature disclosure of the authorities' policy intentions in published staff reports and other documents.

Copies of this report are available to the public from International Monetary Fund • Publication Services PO Box $92780 \bullet$ Washington, D.C. 20090 Telephone: (202) 623-7430 • Fax: (202) 623-7201 E-mail: publications@imf.org Web: http://www.imf.org Price: $\$ 18.00$ per printed copy

\section{International Monetary Fund Washington, D.C.}


Press Release No. 17/259

FOR IMMEDIATE RELEASE

July 5,2017
International Monetary Fund

Washington, D.C. 20431 USA

\section{IMF Executive Board Concludes 2017 Article IV Consultation with Norway}

The Executive Board of the International Monetary Fund (IMF) concluded the Article IV Consultation ${ }^{1}$ with Norway on June 30, 2017 and considered and endorsed the staff appraisal without a meeting on a lapse-of-time basis ${ }^{2}$.

Following two years of economic downturn, the Norwegian economy is slowly recovering from the oil shock as domestic demand grew stronger aided by accommodative macroeconomic policies.

Unemployment has been trending down since last summer's peak. Inflation declined recently due to the pass-through of krone appreciation, but expectations remain well-anchored. In addition, banks remain profitable and well capitalized. However, household debt built up further, and house prices continue to rise albeit at a slower pace in recent months.

Mainland growth is projected to increase from just below 1 percent in 2016 to $1 \frac{3 / 4}{4}$ and 21/4 percent in 2017 and 2018 respectively, supported by the recovery of exports and stronger private demand. Oil investment will continue to decline this year, but to a lesser extent before rising moderately in 2018. As demand grows stronger and capacity constraints relax further, unemployment rate is expected to gradually decline to just below 4 percent by 2018. Inflation is projected to edge down further in pace with the unwinding of krone depreciation, before converging to the target over the medium term as trading-partner inflation rises.

The baseline outlook is subject to external risks of weaker than expected global growth, which could delay the recovery of non-oil exports; re-emergence of European bank stress and policy uncertainties in Europe, which could increase financial market volatilities and lead to liquidity strains in banks with high dependence on wholesale funding; and lower energy prices, which could weigh on the recovery. On the domestic side, the risks of ineffective integration of immigrants and refugees to productive employment

\footnotetext{
${ }^{1}$ Under Article IV of the IMF's Articles of Agreement, the IMF holds bilateral discussions with members, usually every year. A staff team visits the country, collects economic and financial information, and discusses with officials the country's economic developments and policies. On return to headquarters, the staff prepares a report, which forms the basis for discussion by the Executive Board.

${ }^{2}$ The Executive Board takes decisions under its lapse-of-time procedure when the Board agrees that a proposal can be considered without convening formal discussions.
} 
could hinder the progress of economic transition. A substantial correction of house prices could dampen consumption and corporate earnings, creating negative spillovers on banks' balance sheets.

The 2016 fiscal outturn implied a stimulus of 0.6 percent of mainland trend GDP. The non-oil structural balance, at 7.2 percent of mainland trend GDP (equivalent to 2.6 percent of GPFG), was still well below the fiscal target of 4 percent of GPFG. The 2017 budget entails further stimulus given the economic slack, generating a slightly smaller fiscal impulse of 0.5 percent of GDP. This is consistent with a tighter fiscal target from 2017 onwards, based on government's decision to lower the target from 4 to 3 percent along with the adjustment of equity share from 62.5 to 70 percent of the investment portfolio.

\section{Executive Board Assessment}

In concluding the 2017 Article IV consultation with Norway, Executive Directors endorsed staff's appraisal as follows:

The mainland economy is bottoming out from the oil-related downturn and is expected to continue to recover at a modest pace. Stronger domestic demand supported by accommodative fiscal and monetary policies has underpinned a recovery since late 2016 and unemployment has started falling. Inflation expectations remain well anchored despite recent declines in inflation due to low wage growth and earlier krone appreciation. The recovery is expected to continue with improving consumer and business confidence and expanding production. But housing market vulnerability has risen with overvalued and rising house prices and elevated household debt.

Norway's external position is moderately weaker than implied by medium term fundamentals. While Norway's net international investment position remains strong, the current account position has weakened as oil prices remain low and non-oil tradable exporters continue to face cost competitiveness challenges, especially given moderate appreciation of Norway's real exchange rate during 2016. While there has been some progress in rebalancing economic activity toward the non-oil sector, it remains incomplete. Further structural reforms to improve cost competitiveness and productivity growth would support this economic rebalancing and improve non-oil export performance.

Advancing the economic rebalancing towards a less oil and gas dependent growth model is becoming more urgent. With lower oil prices seemingly the new norm, sustaining longer-term growth will need to rely on boosting non-oil sector activities, which is challenging given low productivity growth, high labor costs, and falling labor force participation rates among immigrants, men, and the young in face of an aging population. Addressing the challenges requires reallocating resources to the non-oil sectors, reviving productivity growth, further improving cost competitiveness, and promoting high-skilled labor supply.

The expansionary fiscal stance is broadly appropriate this year, provided the measures are pro-transition. The further fiscal stimulus in 2017 appropriately supports the recovery, with measures to combat unemployment, improve infrastructure and R\&D, and implement the tax reform. Given the significant output gap, fiscal policy should remain supportive until the recovery is on a more solid footing, and the stimulus measures should facilitate a smooth economic transition. As growth gathers steam, the fiscal stance should converge to neutral to help contain Dutch Disease effects. The recent tightening of the fiscal 
rule is welcome as it helps conserve oil revenue to address aging-related fiscal challenges. Further tax reforms should be considered to promote an efficient allocation of resources and sustain longer term growth.

Monetary policy should stay accommodative. Given the slack in the economy and weakened inflation outlook, maintaining an accommodative monetary policy stance is appropriate pending a durable recovery. Further easing could be considered in the event of significant downside surprises on growth and inflation. Financial stability concerns arising from a "low for long" interest rate environment warrant great caution, but they should be addressed primarily through macroprudential measures as well as tax and housing market reforms.

Significant policy actions have been taken to address financial stability risks, but continued vigilance and further measures are needed. Financial vulnerabilities have increased in the context of overvalued and rising housing prices, increasingly elevated household debt and higher money market premia. Important steps have been taken to cope with the build-up of financial imbalances, including recent decisions to raise the $\mathrm{CCB}$, tighten mortgage regulations, and introduce the DTI limit and LR requirements. However, continued vigilance is needed and further targeted measures should be considered if vulnerabilities in the housing sector intensify. The close supervision on banks' risk management and underwriting standards in the CRE sector, as well as efforts to increase CRE risk weights and to apply capital add-ons on banks with high concentration on CRE lending, should continue. Deployment of macroprudential tools to contain banks' CRE exposures, such as loan-to-value (LTV) limits and/or a sectoral CCB, should be biased to being ahead of the curve. Moreover, macroprudential policies should be reinforced by tax and housing market reforms, including reducing tax preferences for housing, relaxing constraints on new property construction, and developing the rental market. The authorities should also implement the liquidity coverage ratio requirements in significant currencies-currently under consideration - and continue to enhance stress tests for banks to take account of funding risks.

A successful economic transition hinges on continued structural reforms. Wage restraint and labor market reforms should continue to improve cost competitiveness, facilitate economic rebalancing, and support labor supply. Reviving the growth engine in the non-oil sector also hinges on promoting high-quality employment and boosting productivity through reforms to education, innovation, and product market regulations. In addition, further reforms to the public-sector pension system and sickness and disability benefits will help promote labor force participation. There is also scope for efficiency gains from lowering the level of protection and subsidies for agriculture. 


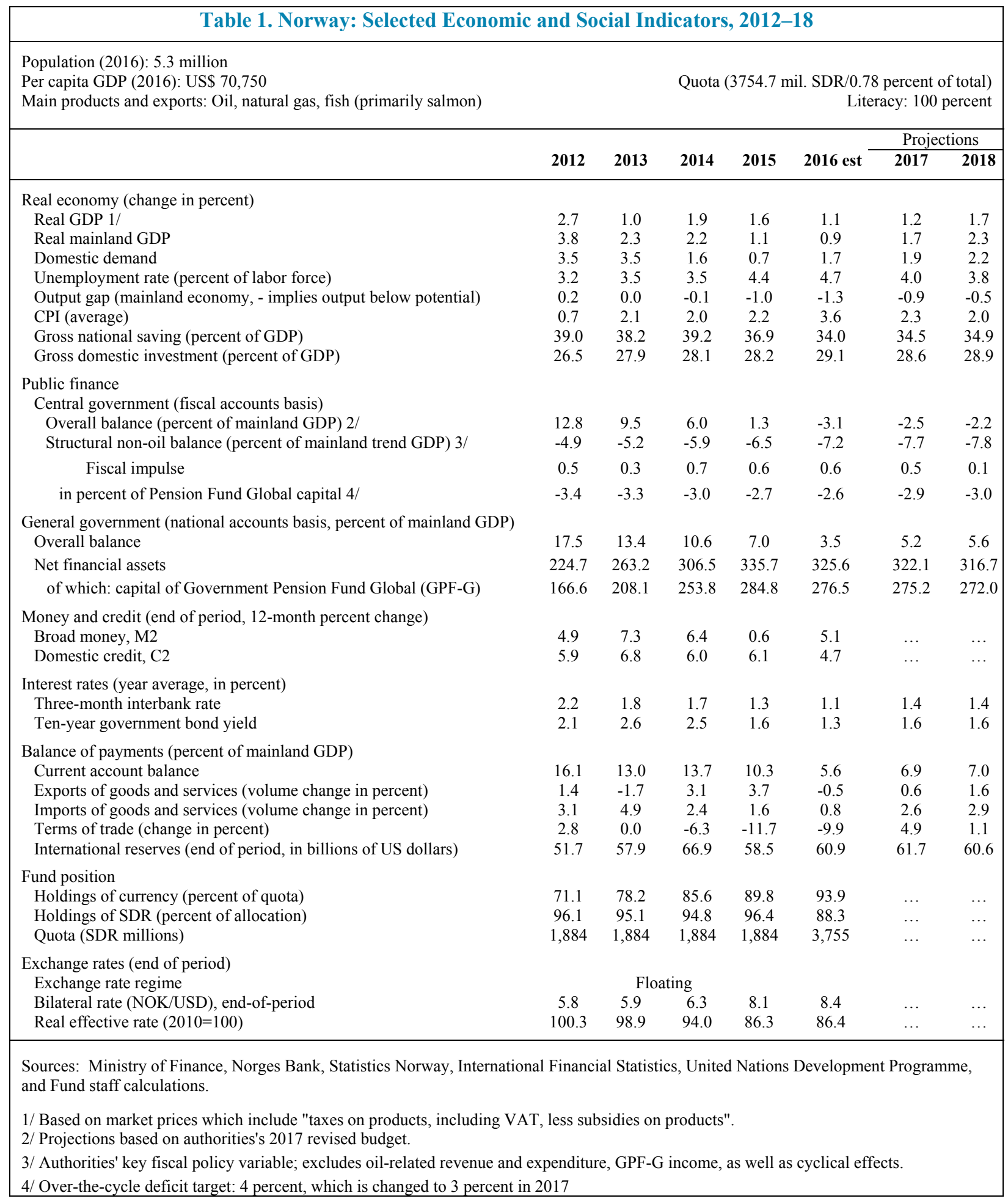

\section{CInternational Monetary Fund. Not for Redistribution}




\section{INTERNATIONAL MONETARY FUND}

\section{NORWAY}

June 15, 2017

\section{STAFF REPORT FOR THE 2017 ARTICLE IV CONSULTATION}

\section{KEY ISSUES}

Context: The sharp oil price slump in 2014-15 has hurt Norway's oil and gas sector, with spillover effects on supporting industries across the supply chain. Mainland growth fell to its lowest level since the $2008 / 09$ crisis at only 0.9 percent last year. However, the economy turned the corner late last year, supported by domestic demand, with unemployment falling from last summer's peak. Meanwhile, house price inflation accelerated to double digits in the second half of 2016, resulting in a further build-up of imbalances. Productivity growth has been low since the mid-2000s and labor force participation rates are falling, particularly for men and the young, in the face of aging.

- Fiscal policy: The further fiscal stimulus in 2017 is appropriate to support the recovery. Nevertheless, the measures need to promote productivity growth and resource reallocation to the non-oil sector. The recent tightening of the fiscal rule is welcome, in line with staff's advice, to conserve oil revenue to address aging-related fiscal challenges in the long-run. As growth approaches potential, the fiscal stance should converge to neutral to contain further Dutch Disease effects.

- Monetary policy: Monetary policy should stay accommodative given the still negative output gap and weakened inflation outlook. Further easing could be considered should growth and inflation falter significantly. Financial stability risks warrant close watching but should be addressed primarily through macroprudential and other measures.

- Financial sector and housing policies: Vulnerabilities in the financial system have increased in the context of high and rising property prices and elevated household debt. While bank balance sheets are strong and significant progress has been made to address key risks, continued vigilance and further measures are needed. In particular, reducing tax incentives for housing and other measures are key to enhancing the longterm macro-financial resilience of the economy to housing market shocks.

- Structural policy: Wage restraint on the part of social partners and labor market reforms should continue to improve cost competitiveness and support labor supply. A successful economic transition also hinges on supporting high-quality employment and boosting productivity through reforms to education, innovation, and product market regulations. 
Approved By Philip Gerson and

Daria Zakharova
Discussions took place in Oslo during May 15-23, 2017. The staff team was comprised of Messrs. Dorsey (head) and Henn, Mmes. Geng and Zhang supported by Mr. Scutaru and Ms. Tenali at headquarters (all EUR). Ms. Sand (OED) joined the discussions.

\section{CONTENTS}

CONTEXT: THE ECONOMY HAS BOTTOMED OUT

OUTLOOK: MODEST RECOVERY AMID UNCERTAINTIES

A. Fiscal Policy: Promoting Structural Adjustment and Efficiency ___ 11

B. Monetary Policy: Supporting the Recovery and Price Stability ___ 14

C. Financial Sector and Housing Policies: Safeguarding Financial Stability___ $\underline{15}$

D. Structural Policy: Restoring Competitiveness, Facilitating the Transition, and Raising Growth Potential

\section{BOX}

1. Risk Assessment Matrix

\section{FIGURES}

1. GDP and Activity Indicators $\underline{26}$

2. Labor Market Developments $\underline{27}$

3. Price Developments $\underline{28}$

4. External Sector Developments $\underline{29}$

5. Credit Developments $\underline{30}$

6. Household Sector Developments $\underline{31}$

7. Corporate Sector Developments $\underline{32}$

8. Banking Sector Developments $\underline{33}$

\section{TABLES}

1. Structural Gaps $\underline{22}$

2. Selected Economic and Social Indicators $\underline{34}$

3. Medium-Term Indicators, 2013-2022 $\underline{35}$

4. External Indicators, 2013-2022 $\underline{36}$

5. General Government Accounts, 2006-2015 $\underline{37}$ 


\section{ANNEXES}

I. External Sector Assessment $\underline{39}$

II. Authorities' Response to Past IMF Recommendations

III. Status of FSAP Recommendations $\underline{44}$

IV. Debt Sustainability Analysis 


\section{CONTEXT: THE ECONOMY HAS BOTTOMED OUT}

1. Norway will hold general elections on September 11, 2017. The current center-right minority coalition government, comprising the Conservatives and the Progress Party, will face new elections this September with a new government likely to be formed by mid-October." However, broad cross-party consensus typically delivers a high level of continuity on economic policy.

2. The economy is slowly recovering from the oil price shock. Mainland (i.e. non-oil and gas) growth was only 0.9 percent in 2016 - the weakest pace of expansion since the 2008/09 crisis. However, growth gradually picked up over the course of the year, supported by accommodative macroeconomic policies and improving sentiment. The key drivers were public sector demand, household consumption, reviving business investment, and buoyant housing investment. Also, there is less drag from reduced oil investment. However, non-oil exports declined, partly reflecting the temporary shutdowns of several large industrial enterprises in the second half of 2016 due to production upgrades or outages. Mainland GDP expanded by 0.6 percent $(q / q)$ in the first quarter of 2017, up from 0.4 percent (q/q) in the previous quarter, supported by the revived growth in non-oil exports (Figure 1).

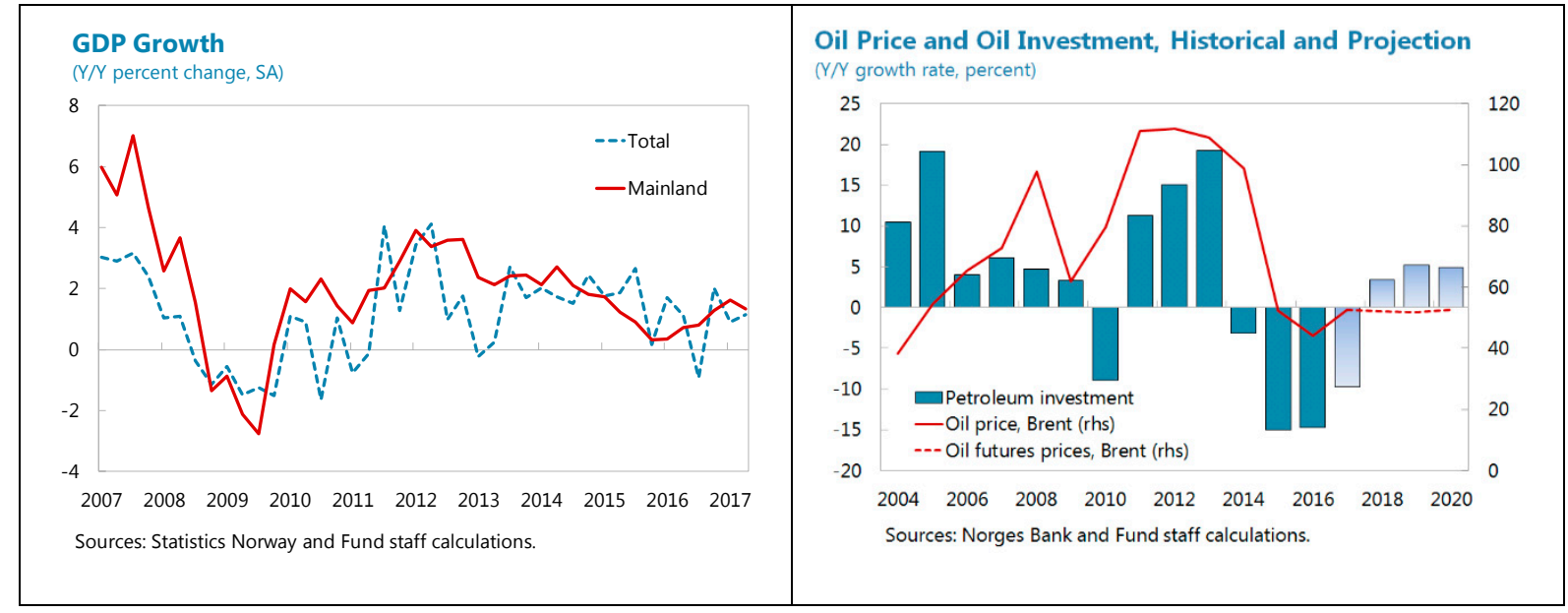

3. Unemployment is gradually declining from last year's peak (Figure 2). The seasonallyadjusted Labor Force Survey (LFS) unemployment rate trended down from its peak of 4.9 percent last July/August to 4.5 percent in March. Registered unemployment shows a similar trend, albeit more stable and at lower levels. ${ }^{1}$ Yet the national figure masks wide regional variation, with unemployment still rising in the Rogaland region as of 2017Q1-home to the oil capital of Stavanger-while starting to recede in other parts of the country. Divergence also remains between different population groups, with unemployment still higher-though most recently also declining - for men and the young. Meanwhile, wage growth was 1.7 percent last year-down from 2.8 percent in 2015 .

\footnotetext{
${ }^{1}$ This measure likely excludes those who are unemployed but ineligible for unemployment benefits, e.g. students.
} 


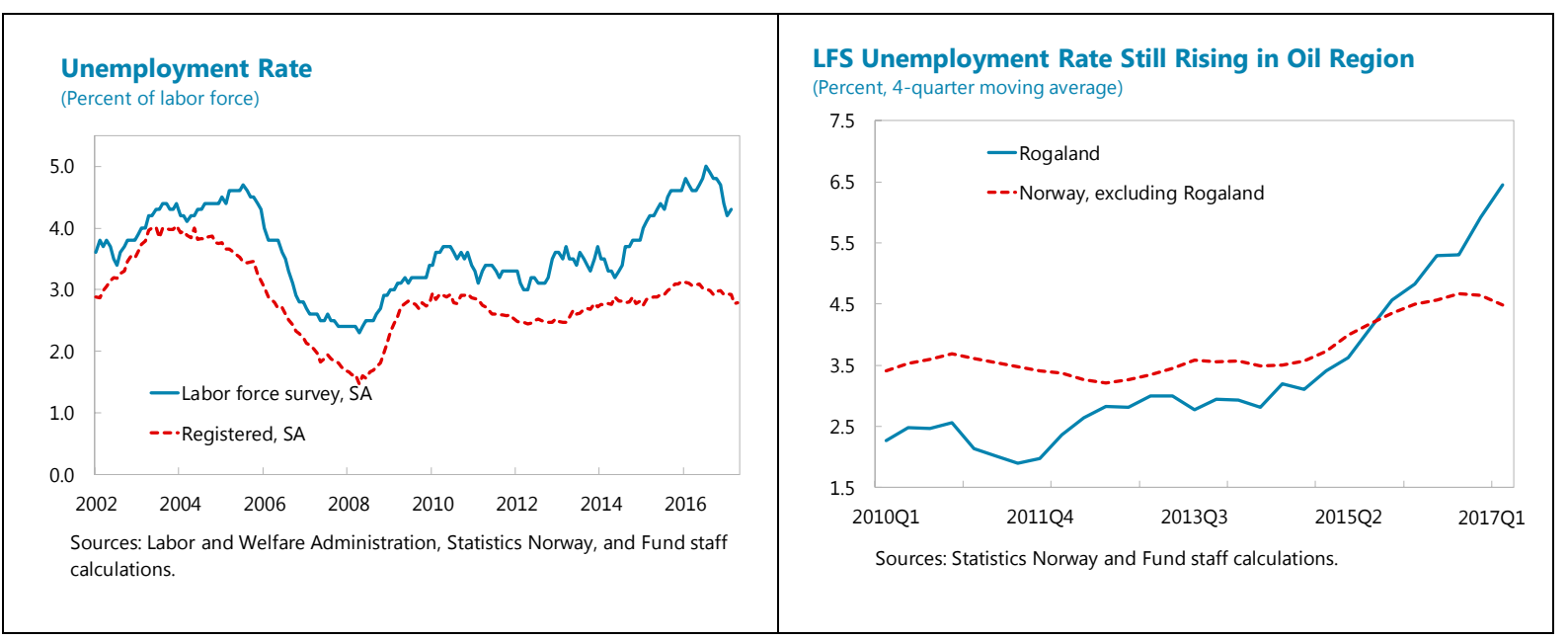

4. Nevertheless, there are challenges to integrating certain groups into the labor market. Net immigration - a major factor contributing to labor force growth in the past-has been sliding due to the economic downturn. While labor participation for women has held relatively stable at a high level, that for men has dropped by some 3 percentage points since 2009, partly because traditionally male-dominated sectors (e.g., manufacturing) were harder hit by the crisis, with one in seven prime age (25-54) males currently out of the labor force. Moreover, integration of youths into the labor market is a growing challenge with dropout rates from formal education still high and more young people claiming disability benefits (Figure 2 ). ${ }^{2}$ Despite recent progress, employment rates of non-OECD immigrants remain substantially lower than those of natives.
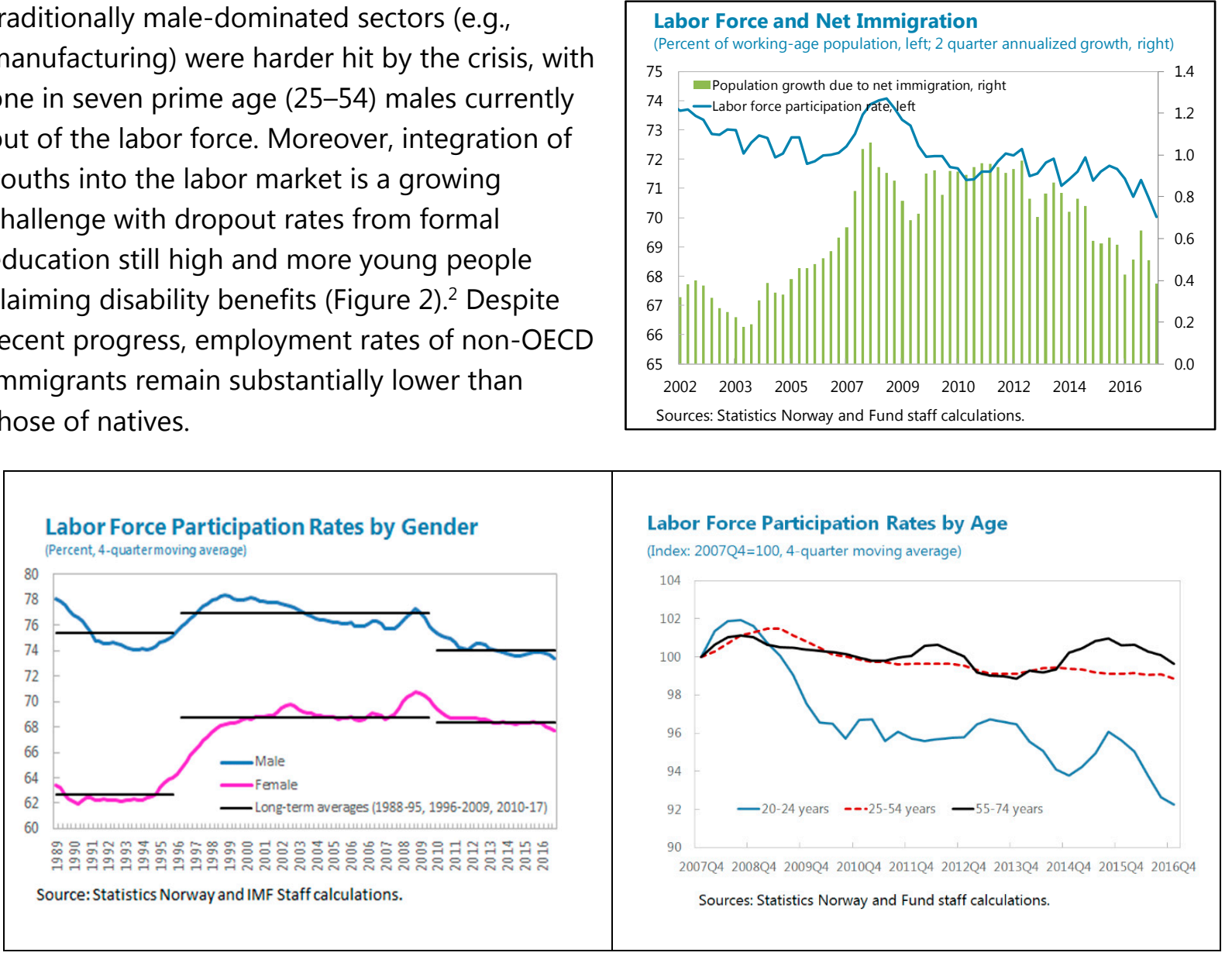

${ }^{2}$ See Chapter 3 of the Selected Issues. 
5. Following substantial depreciation for three years, the krone has strengthened somewhat through 2016 and into early 2017 along with the recovery of oil prices (Figure 4). The import-weighted nominal exchange rate is about 3 percent stronger than its weakest level in early 2016 in pace with the rise in oil prices and a widening of the interest rate differential against trading partners. The krone depreciation during 2013-15 coupled with low wage growth has helped reverse some of the long-term deterioration in Norway's cost competitiveness, supporting strong tourism exports and some recovery of traditional manufacturing exports. Real effective exchange rates on both CPI and unit labor cost (ULC) bases are around their two-decade averages. The current account surplus narrowed further in 2016, driven mostly by further decline in oil-related exports. Staff assesses Norway's external position to be moderately weaker than implied by economic fundamentals (Annex I).

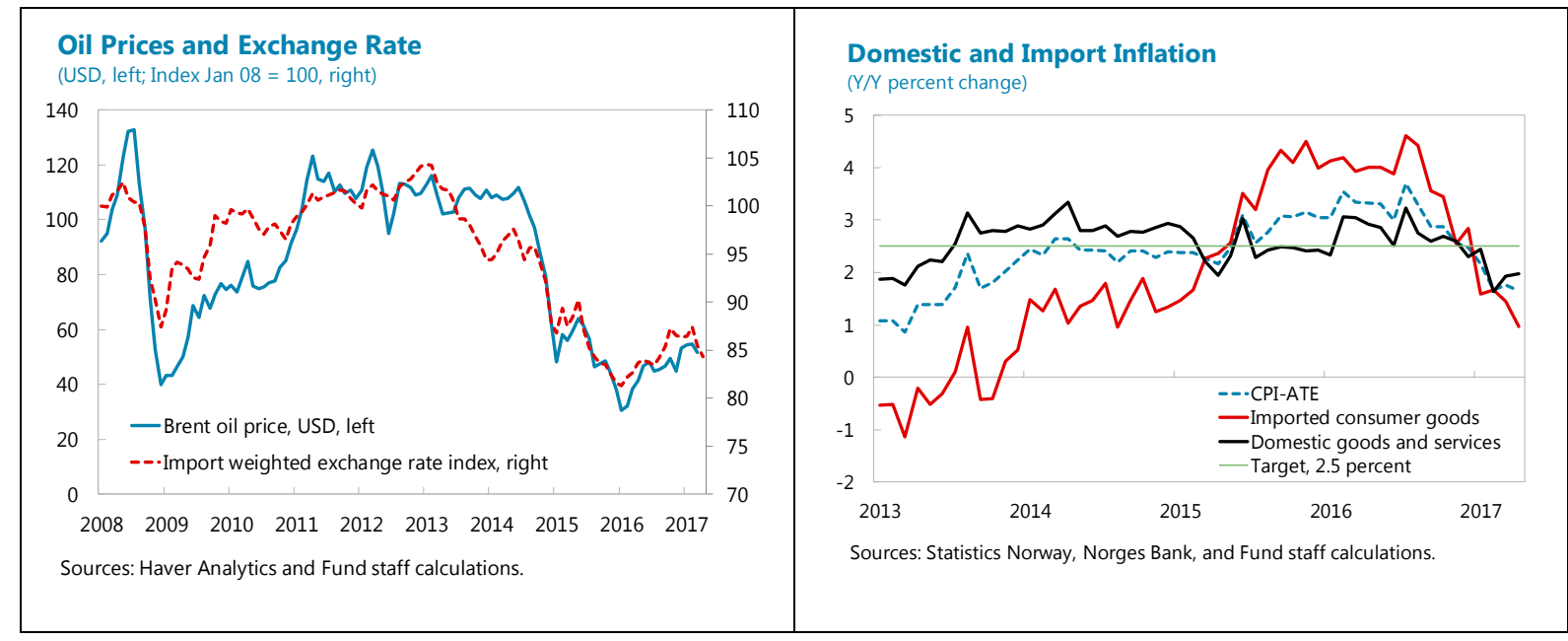

6. Exchange rate dynamics have been playing the primary role in shaping recent inflation developments (Figure 3). Inflation last year reached its highest level since the 2008/09 crisis, with headline CPI and core inflation averaging 3.6 and 3.0 percent respectively. ${ }^{3}$ Yet, following krone appreciation, inflation has been falling since last summer and core inflation stood at 1.7 percent in April. This largely reflects the pass-through from the exchange rate to import prices as imported goods constitute about $1 / 3$ of the consumption basket. Recently, inflation of domestically produced goods and services showed some weakness-due to sharply lower wage growth last year-before rebounding starting in March. Owing to faster energy price rises, headline inflation continued to be higher than core inflation, remaining close to the 2.5 percent inflation target. Meanwhile, inflation expectations are stable.

\footnotetext{
${ }^{3}$ Core inflation in Norway is measured by change in CPI-ATE, i.e. adjusted for tax changes and excluding energy products.
} 


\section{House price inflation accelerated to double digits in the second half of last year,} resulting in a further build-up of imbalances, yet some early signs of softening in market conditions emerged recently (Figure 6). House prices nation-wide rose at an average pace of 7.1 percent $y / y$ in 2016 - up from 6.1 percent $y / y$ in 2015. The pace has been picking up throughout the year in most parts of the country, and is particularly high in the Oslo area (21.7 percent y/y in 2016 Q4). Nevertheless, the pace of house price increase slowed down slightly in recent months. Residential investment has risen in response to higher prices, but housing starts remained below estimated household formation until recently. With house

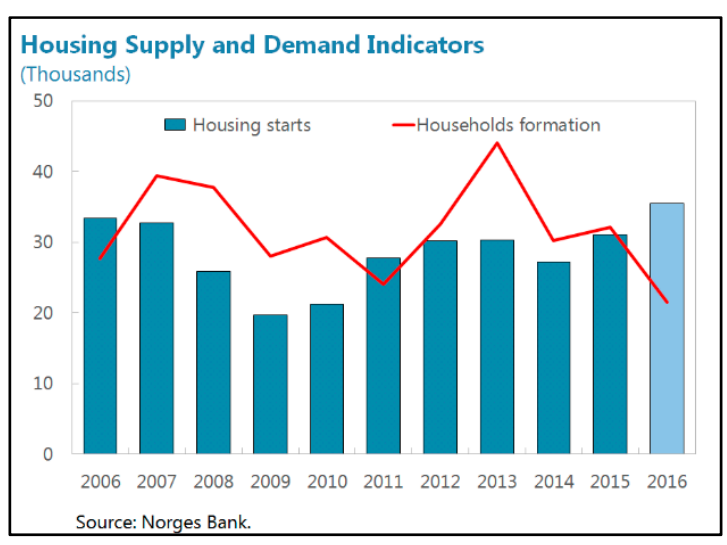
prices rising ahead of income, the average cost of a home relative to the median household income has almost doubled since the mid-1990s, and is high relative to a range of countries. In Oslo, the ratio has soared to nearly twice the national average and is among the highest in major cities worldwide. Household debt as a share of disposable income continued to increase from elevated levels, standing at 227 percent as of end-2016.

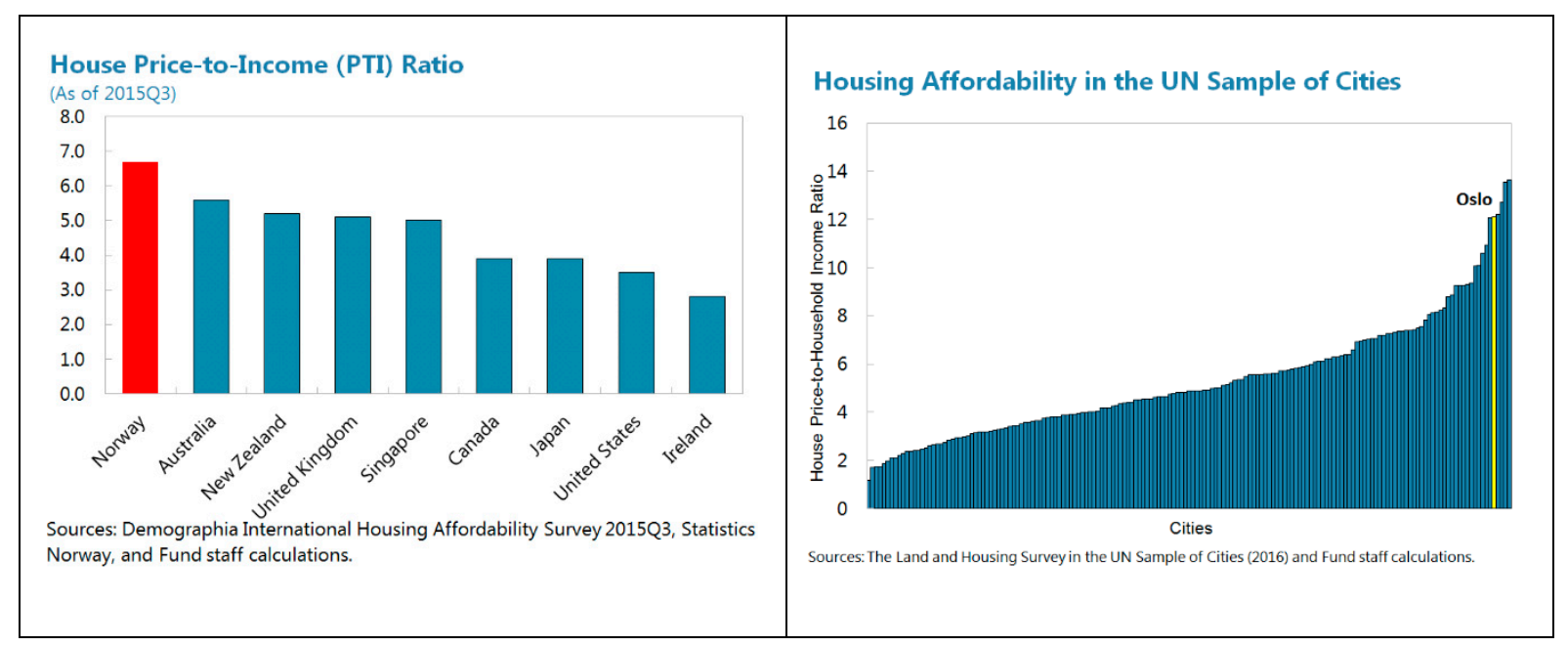

8. The inflow of asylum seekers has subsided following the large influx in 2015. Norway received over 31,000 first-time asylum applicants ( 0.6 percent of the population) in 2015 . Yet the inflow to Norway was dramatically lower in 2016 at about 3,500 owing to tighter border controls in other European countries. The low arrival numbers continued into 2017, with two-third of the applicants so far transferred under the EU relocation scheme. The authorities' latest forecast is for about 8,250 refugees this year, though this is subject to significant uncertainty. 


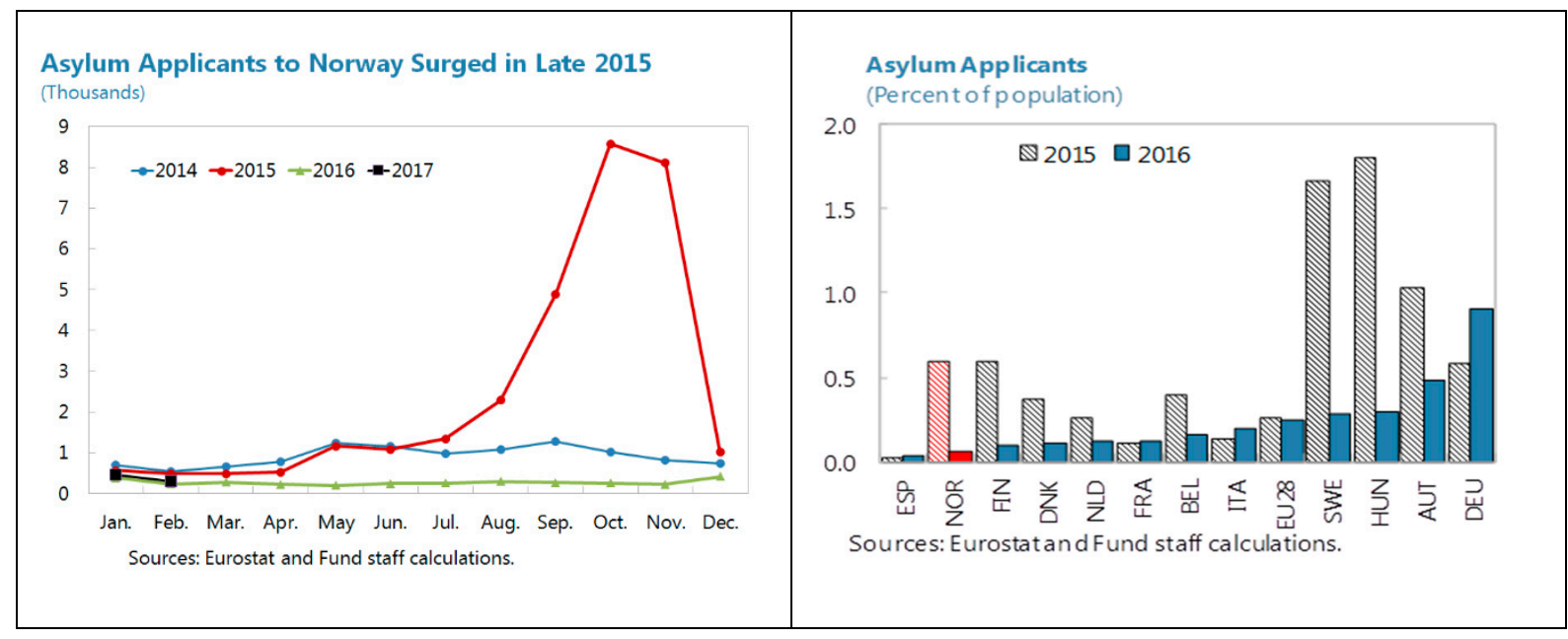

9. Traction of Fund advice has been very good (see Annexes II and III). Most of Fund recommendations have been implemented from the 2016 and earlier Article IV consultations, and from the 2015 Financial System Stability Assessment (FSSA), notably the downward revision of the fiscal rule, the tightening of mortgage regulations, and the introduction of the debt-to-income (DTI) limit.

\section{OUTLOOK: MODEST RECOVERY AMID UNCERTAINTIES}

10. The near-term outlook is for a modest recovery and low inflation. Following two years of slow growth, the economy has shown signs of recovery (Figure 1). Capacity constraints for the manufacturing sector are expected to relax given improving business investment. Alongside stronger foreign demand, this should lead to a recovery in exports this year. Mainland growth is projected to pick up to $13 / 4$ percent this year and $2 \frac{1}{4}$ percent next year, underpinned by higher business investment and mainland exports while private consumption stays strong. Petroleum investment will continue to decline this year, but at a slower pace, before rising moderately after 2018. Accommodative monetary conditions and the global economic recovery will support the recovery, while the contribution from fiscal policy will be more constrained after the tightening of the fiscal rule. The unemployment rate is expected to gradually decline to 3.8 percent in 2018 . Inflation is projected to decline further in pace with the unwinding of krone depreciation, before converging to the target over the medium term as wage growth and trading-partner inflation rise. 


\begin{tabular}{|c|c|c|c|c|}
\hline $\begin{array}{l}\text { Growth outlook by industries, next six months } \\
(\% \mathrm{y} / \mathrm{y}) \\
4\end{array}$ & \multirow{3}{*}{\multicolumn{2}{|c|}{$\begin{array}{c}\text { Norway: Selected Economic Indicat } \\
\text { (y/y percent change, unless noted) }\end{array}$}} & & \\
\hline $3-11$ & & & \multicolumn{2}{|c|}{ Projections } \\
\hline 2 x.s. & & & 2017 & 2018 \\
\hline 10 in & Real GDP & 1.1 & 1.2 & 1.7 \\
\hline , & Real mainland GDP & 0.9 & 1.7 & 2.3 \\
\hline 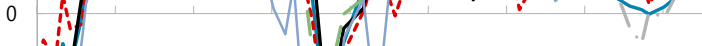 & Domestic demand & 1.7 & 1.9 & 2.2 \\
\hline-1 利 & Mainland exports of G\&S & -5.4 & 2.4 & 3.5 \\
\hline$N$-All & Unemployment rate (percent of labor force, LF & 4.7 & 4.0 & 3.8 \\
\hline$-2 \quad-$ Commercial Services & Output gap (percent of potential GDP) & -1.3 & -0.9 & -0.5 \\
\hline - Construction & CPI inflation (average, percent) & 3.6 & 2.3 & 2.0 \\
\hline $\begin{array}{l}\text { Oct-02 Jun-04 Feb-06 Oct-07 Jun-09 Feb-11 Oct-12 Jun-14 Feb-16 } \\
\text { Sources: Regional Network Survey Report }\end{array}$ & $\begin{array}{l}\text { Sources: IMF World Economic Outlook, Statistic } \\
\text { and staff calculation }\end{array}$ & s Norw & & \\
\hline
\end{tabular}

\section{Boosting growth potential in the non-oil sector is crucial for reviving the economy.}

Growth of the petroleum industry will remain sluggish in the medium term as oil prices stay low, highlighting the importance for the economy to adjust to a new growth model with lower petroleum income. However, productivity growth in the non-oil sector remains weak and labor supply is falling owing to the aging of the population, posing challenges to a successful economic transition. Staff's central forecast assumes a smooth transition for the mainland economy and potential growth of about 2.2 percent in the medium term. This assumes successful implementation of tax and structural reforms that the government has proposed. The medium-term forecast, however, is still lower than the 10-year average before the global financial crisis, considering the aging population and moderate productivity growth. To further boost potential growth, it is crucial to sustain labor supply growth, improve cost competitiveness, and revive productivity

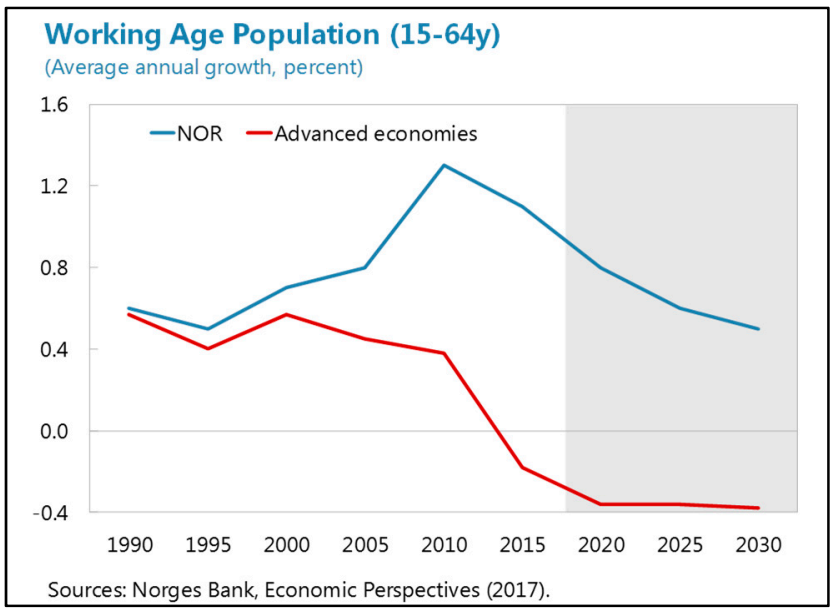
growth.

\section{Risks are tilted to the downside, but they have become more balanced (also see Box 1).}

External risks have subsided somewhat. The baseline assumes that oil prices stay around current levels, and the risk of a further decline is low.

- However, the risk of weaker global growth continues to cloud the outlook. Slower growth in major economies could dampen external demand for mainland goods and services, hindering the recovery of non-oil exports. It would put further downward pressure on oil prices, 
intensifying the downturn in oil-related industries and exacerbating the adverse spillover effects to the rest of the economy.

- Global financial conditions could tighten faster and more sharply than anticipated. Reemergence of European bank distress could renew stress in the wholesale funding market, leading to liquidity strains.

Domestic risks remain elevated, especially in the housing market. The economic impact of a housing market hard landing can be further amplified through the interlinkages with the oil sector and macroeconomic developments.

- A substantial correction in property prices could result in a sharp reduction in domestic demand and output. A large correction of house prices, driven by slower real income growth, a reverse in sentiment, or interest rate hikes could weaken household balance sheets and depress private demand, and in turn adversely affect corporate and bank earnings. Staff analysis suggests that a 10 percent decline in real house prices could reduce private consumption by 0.9 percent. ${ }^{4}$

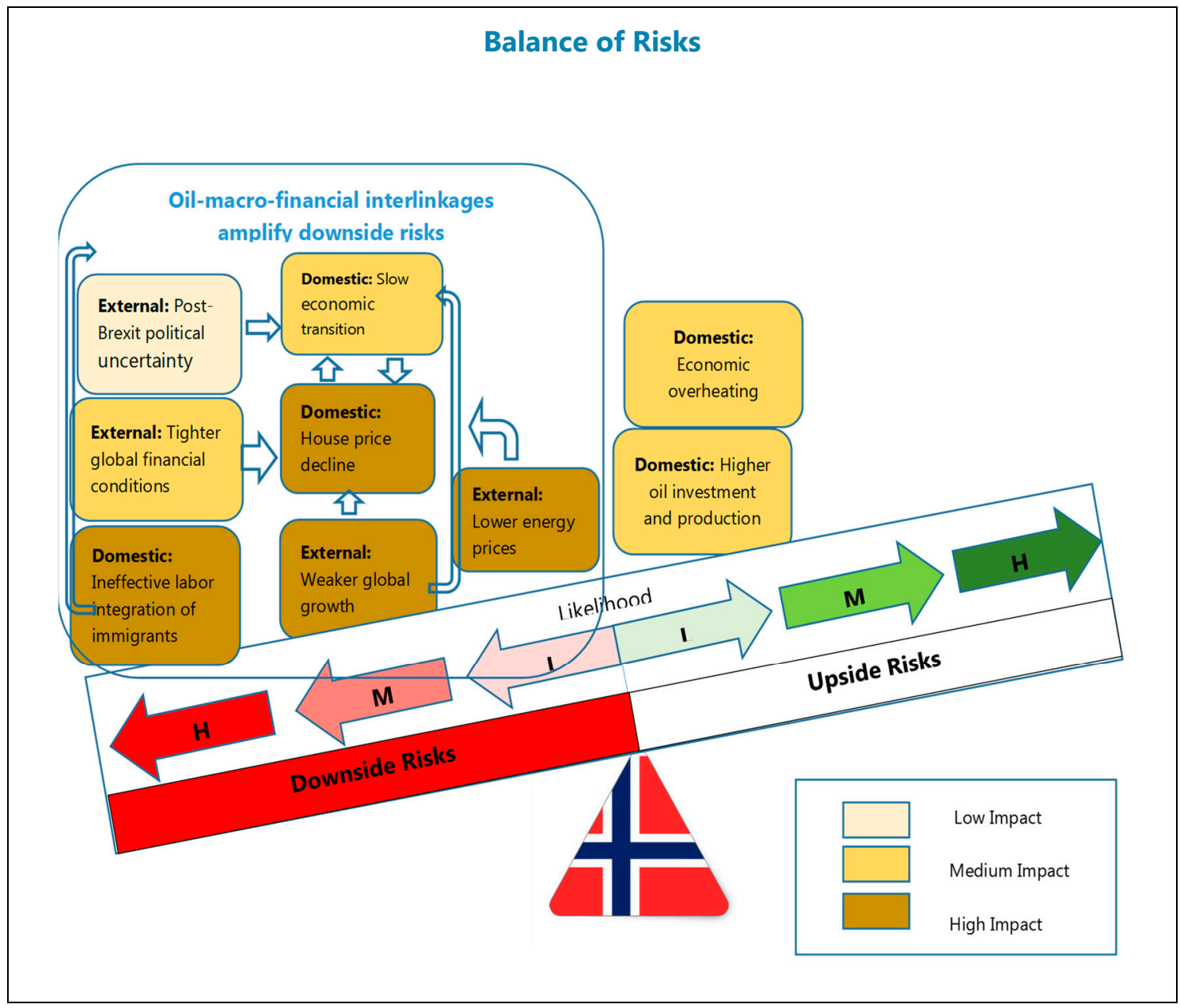

\footnotetext{
${ }^{4}$ See IMF Country Report No. 15/429.
} 
- The economic transition could take longer than expected. Lack of wage adjustment and stagnant productivity growth, weak business investments, and a shortage of skilled labor supply caused by slower reforms, and unsuccessful labor market integration of refugees could hinder the economic transition.

- The economy may recover faster than expected as stronger global demand and consumer and business confidence could lead to higher exports and domestic demand..

- Petroleum investment may surprise on the upside. The petroleum investment outturn for 2016 appears stronger than anticipated earlier in the year. The medium-term projection has also been revised upward. If oil prices were to rise more than expected as global economic recovery takes on stronger momentum and cost-reduction measures lower development costs further, more projects will become profitable on the Norwegian continental shelf and abroad, leading to higher petroleum investment.

\section{Authorities' Views}

13. The authorities shared staff views on macroeconomic outlook and risks. They agreed that stronger consumer and business confidence points to continued and broad-based recovery. They also noted that, while housing investment would moderate as house price appreciation slows down further, industrial investment would pick up. Despite the recent recovery of non-oil exports supported by improving cost competitiveness, the authorities noted that the economic transition to a more balanced growth model less dependent on oil- and gas-related demand would be a gradual process. On risks, they noted that improved cost efficiency in oil exploitation and production has lowered breakeven oil prices; hence the economy should be less vulnerable to an oil price shock. The macroeconomic implication of a house price correction should be manageable without taking extraordinary measures unless household disposable income also falls sharply.

\section{POLICY DISCUSSIONS}

\section{The policy mix should safeguard a steady recovery and sustained long-term growth} while protecting financial stability. Macroeconomic policies should aim to support the adjustment of the economy to the new norm of low oil prices. A successful transition to a new growth model less dependent on oil and gas requires a well-qualified labor force and a productive business sector. Labor market policies and structural reforms are therefore key to reviving productivity and promoting high-quality labor supply, thereby securing sustained growth. Also, further measures are needed to address the vulnerabilities in the financial system.

\section{A. Fiscal Policy: Promoting Structural Adjustment and Efficiency}

15. The $\mathbf{2 0 1 6}$ fiscal outturn implied a $\mathbf{0 . 6}$ percent fiscal expansion. The structural non-oil deficit increased to 7.2 percent of mainland trend GDP in 2016, equivalent to 2.6 percent of the balance of the Government Pension Fund Global (GPFG), well-below the 4 percent "target" of the 
fiscal rule. ${ }^{5}$ Due to low oil and gas revenue, the fiscal stimulus led to a net withdrawal from the GPFG fund, for the first time in the fund's history.

\section{The $\mathbf{2 0 1 7}$ budget entails a further but} smaller fiscal stimulus. The budget forecasts a structural non-oil deficit of about 7.7 percent of mainland GDP, or 2.9 percent of GPFG assets at end-2016. This represents a fiscal stimulus equivalent to 0.5 percent of mainland GDP. New initiatives include special measures to combat

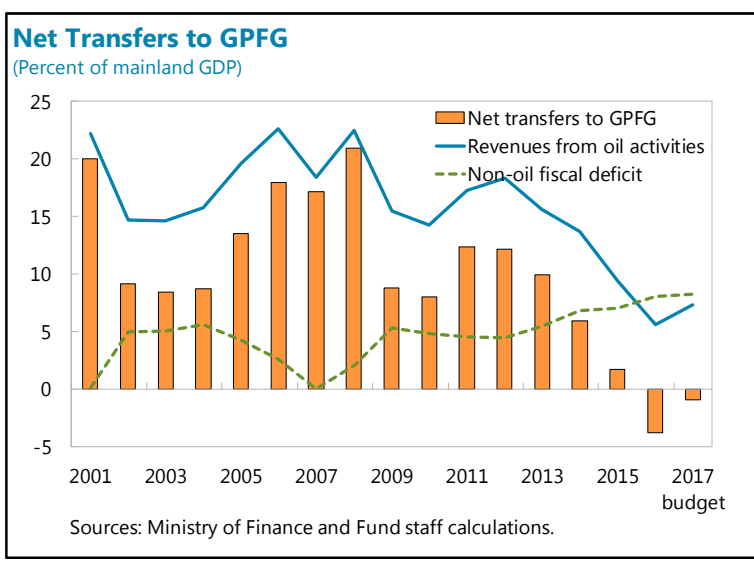
unemployment in the regions and industries most affected by the oil downturn, and higher investments in infrastructure and research and innovation. Implementation of tax reform, including corporate and personal income tax rate cuts from 25 to 24 percent, will continue.

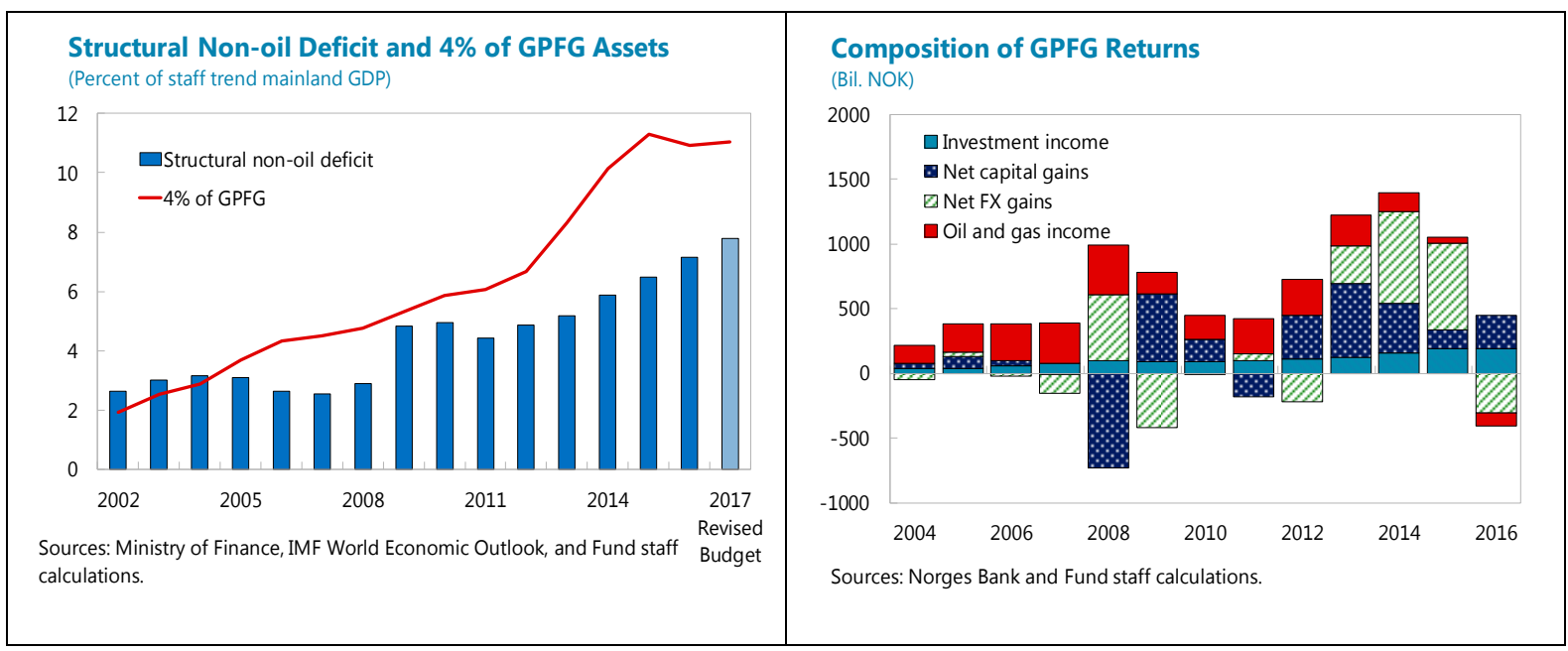

17. The expansionary fiscal stance in $\mathbf{2 0 1 7}$ is justifiable, provided fiscal measures are protransition. Norway has ample fiscal space with an overall surplus above 3 percent of GDP, low gross debt, positive net debt, and a large oil fund earning positive net returns every year. Given the significant mainland output gap, fiscal policy should remain supportive until the recovery is on a more solid footing, especially given the limited monetary policy space to loosen further. The fiscal stimulus shall be used to fund well-targeted measures that improve labor supply and mobility, promote investment, stimulate innovation, and enhance productivity, for example, by providing tax incentives to encourage R\&D and by enhancing spending on education to help integrate young and immigrant workers into the labor market.

\footnotetext{
${ }^{5}$ Fiscal policy is guided by the fiscal rule, stipulating a gradual phasing-in of oil revenues in the Norwegian economy in line with the expected real returns on the Government Pension Fund Global (GPFG). The estimate for the expected real return on the GPFG has recently been reduced from 4 to 3 percent. The fiscal rule permits spending more than the expected return on the Fund in a cyclical downturn, while the use of oil revenues should lie below the expected return when capacity utilization in the economy is high.
} 
18. In line with staff's recommendations, the government decided to tighten the fiscal rule and raise the equity share of the GPFG. The fact that the GPFG has been growing much faster than the economy has allowed increased spending of oil revenues as share of mainland GDP. The new global norm of low interest rates and high equity valuations suggests likely returns to GPFG assets to be considerably lower than 4 percent for the next decade. Considering the lower expected return from fixed income products and higher risk-bearing capacity given better diversified oil wealth, the government announced a tightening of the fiscal rule from 4 to 3 percent, and an increase of the equity share of the GPFG from 62.5 to 70 percent.

\section{Convergence to a broadly neutral stance is appropriate in the medium term. Should} growth fall short of expectations, automatic stabilizers should be allowed to operate freely. However, further fiscal stimulus when output approaches potential should be avoided to contain further Dutch Disease.

\section{Further tax reforms should be considered to promote an efficient allocation of} resources and support longer term growth. Norway's tax burden and the share of income taxes were high by international standards prior to the recent tax reform. The proposed stepwise reduction of corporate and personal ordinary income taxes to 23 percent by 2018, and increases in indirect taxes such as higher reduced VAT rates, the introduction of a financial activity tax ${ }^{6}$, and increases in environmental taxes are welcome steps to reduce the overall tax burden and broaden the tax base. Lower CIT rates would also help prevent the erosion of the tax base from multinational companies' profit shifting. Going forward, further tax reforms should be considered to support longterm growth, including: (i) providing more tax incentives to stimulate R\&D and innovation; (ii) further reducing labor tax wedges, especially for the low skilled, to improve work incentives; (iii) broadening the VAT tax base; and (iv) reducing tax preferences for housing ownership and leverage by eliminating mortgage interest deductibility and raising property taxes. ${ }^{7}$
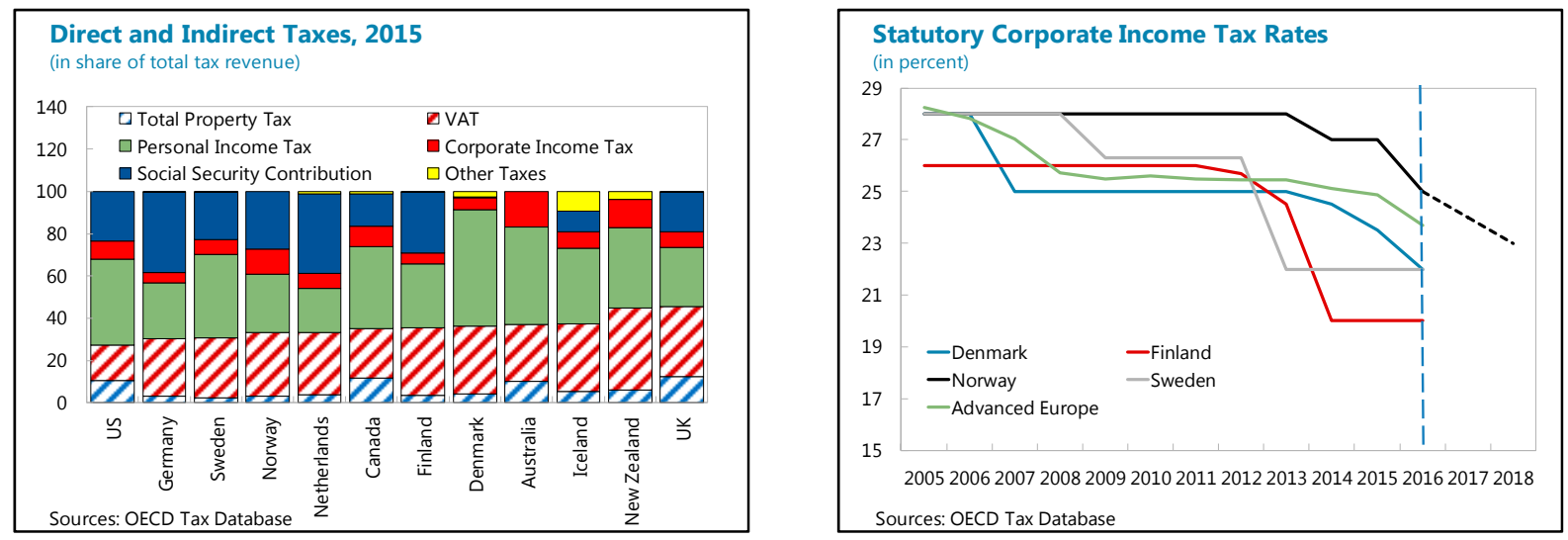

\footnotetext{
${ }^{6}$ Two elements: (i) employers in the financial sector are subject to an extra payroll tax of 5 percent; (ii) The corporate income tax rate (CIT) in the financial sector is maintained at the 2016 level of 25 percent in the future years, while the CIT rate in other sectors are planned to reduce to 23 percent by 2018 .

${ }^{7}$ See Chapter 2 of the Selected Issues.
} 


\section{Authorities' Views}

21. The authorities agreed that fiscal policies should facilitate the economic transition and become less expansionary going forward. They noted the risk of overheating the economy with further fiscal expansion or a delay in rolling back previous stimulus, especially in a low interest rate environment. Hence, in line with staff's recommendations, they emphasized the need to roll back the fiscal stimulus as growth gathers steam. They acknowledged the tax efficiency benefits of tax incentives to promote innovation, but they highlighted the administrative difficulties that could undermine their effectiveness. They saw merit in further aligning the tax valuation base across asset classes, but they noted that any increase in effective tax rates on houses would meet stiff resistance.

\section{B. Monetary Policy: Supporting the Recovery and Price Stability}

22. The key policy rate has been held at $1 / 2$ percent since the rate cut in March 2016. In view of the weaker than expected output and inflation, the Norges Bank (NB) in its recent Monetary Policy Report retained an easing bias and provided forward guidance that it would maintain the policy rate at low levels for a longer period. Monetary conditions are accommodative, although recent developments with inflation and retail interest rates imply some tightening (Figure 5).

\section{The outlook for inflation has weakened with increased uncertainties (Figure 3 ).}

Opposing factors are at play with respect to inflation. The strengthening of the krone through 2016 and early 2017 will continue to exert downward pressures on prices of imported consumer goods, while record low wage growth in 2016 and overall low capacity utilization will weigh on domestic inflation. On the other hand, nominal wage growth is expected to be higher at 2.4 percent in 2017 as the labor market tightens and growth picks up further. In addition, the krone depreciation in recent months will gradually pass through into prices of imported goods, providing support for inflation. Higher growth and interest rates abroad imply higher inflation going forward, partly through a weaker krone and increased exports. Staff's baseline forecast is for inflation to stay slightly below target before gradually returning to target in 2020 .

\section{It is appropriate for monetary policy to stay accommodative pending a durable}

recovery. Given the significant slack in the mainland economy, weakened inflation outlook, and well anchored inflation expectations, staff views the current monetary stance as appropriately supportive. Further easing could be considered if growth falters or inflation surprises significantly on the downside. Nevertheless, the risk from the build-up of financial imbalances and the uncertainty surrounding the effects of a policy rate approaching a lower bound warrant greater caution. The NB should consider embarking on policy tightening and a gradual return

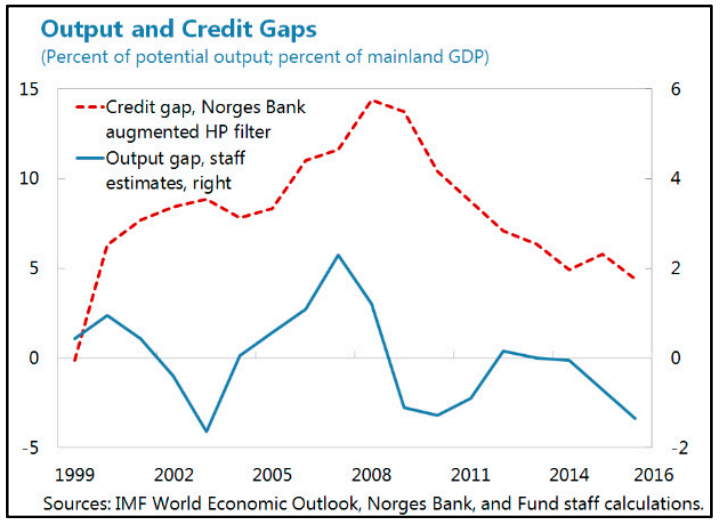
to a neutral policy stance once firm signs of a durable recovery emerge. 


\section{Macroprudential policy should remain the first line of defense in safeguarding} financial stability (see section C). While Norway's flexible inflation targeting framework takes into consideration financial stability risks, monetary policy is a blunt tool to address housing sector vulnerabilities, especially in view of the divergent economic and financial cycles.

\section{Authorities' Views}

26. The authorities shared similar views to staff on monetary policy. The Norges Bank forecasts capacity utilization in the Norwegian economy to rise gradually ahead and inflation to continue to fall until this summer before gradually picking up in medium term. The bank noted that there is still room for maneuver in monetary policy should growth or inflation falter significantly. They will continue to monitor financial stability risks closely and agreed that macroprudential policy is the first line of defense in maintaining financial stability. They noted that by taking into account the risk associated with very low interest rates, monetary policy can promote long-term economic stability.

\section{Financial Sector and Housing Policies: Safeguarding Financial Stability}

27. Vulnerabilities in the financial system have increased in the context of high and rapidly rising property prices, elevated and growing household debt, and higher money market premia:

- Rapidly rising and overvalued house prices: House prices are high and have increased rapidly, especially in the Oslo area. A cross-country econometric analysis suggests the uptrend in real housing prices in Norway is driven by growing incomes, the rising number of households relative to housing supply, low interest rates, and the generous tax relief on housing investment, with a significant estimated overvaluation of about 16 percent as of end-2016. ${ }^{8}$

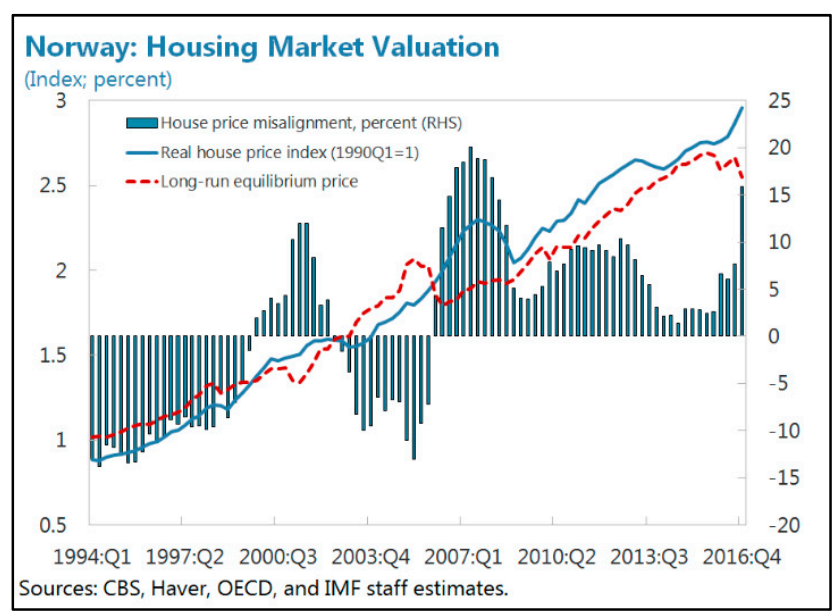

- Large and growing household financial imbalances (Figure $5 \& 6$ ): Household debt is among the highest in the OECD and is skewed toward young households with limited liquid assets. While the share of new mortgage lending with a loan-to-value (LTV) of 85 percent or higher has declined, the share that failed the affordability tests has increased. Moreover, the share of households with a debt-to-income (DTI) ratio higher than 5 has been rising since 2000, with these households mostly residing in urban areas with high house prices. The flip side is increasing concentration of banks' balance sheets in mortgages. Although default risk is low, a

\footnotetext{
${ }^{8}$ See Chapter 1 of the Selected Issues.
} 
large rise in interest rates or severe deterioration in macroeconomic conditions could translate into higher loan losses. ${ }^{9}$

- Commercial real estate (CRE) valuations have increased since the mid-2000s-particularly in Oslo where they have risen more rapidly than residential house prices-though they are within the usual range of variation over the cycle (Figure 7). The CRE sector is a source of vulnerability as it is a large sector historically prone to losses for banks and lending to this sector accounts for a sizable share of banks' lending portfolio, at about 15 percent as of 2017Q1 (Figure 5).

- Banks' reliance on external wholesale funding, especially short-term foreign currency funding, warrants continued vigilance, particularly in view of the higher funding cost from the US money market due to regulatory changes.

28. Meanwhile, banks reported solid profits and have substantially strengthened their balance sheets with regulatory steps (Figure 8). Bank profitability declined slightly, partly due to a rise in loan provisions requested by the FSA, but remains high compared to peers. The NPL ratio edged up-reflecting losses on oil-related exposures—but stayed low. ${ }^{10}$ Norway has been well ahead of schedule in terms of implementing the CRD IV/Basel III requirements, and accordingly the risk-weighted capital ratios of Norwegian banks have improved markedly since 2008, with all banks comfortably meeting Pillar 1 and Pillar 2 requirements, and the upcoming leverage ratio requirements by ample margins. Bank stress tests by both the FSAP mission in 2015 and the NB in 2016 suggest that banks' buffers render them well-positioned to withstand severe shocks. ${ }^{11}$

29. The authorities have been vigilant about the key risks and have made important progress with implementing Article IV and FSAP recommendations

(Annexes II and III). Norway has been leading its European peers in the adoption and use of macroprudential tools. In view of the build-up of financial imbalances, ${ }^{12}$ several decisions were made recently: (i) the countercyclical capital buffer (CCB) will be increased to 2 percent from December 31, 2017; (ii) a new mortgage regulation (effective from 2017 to

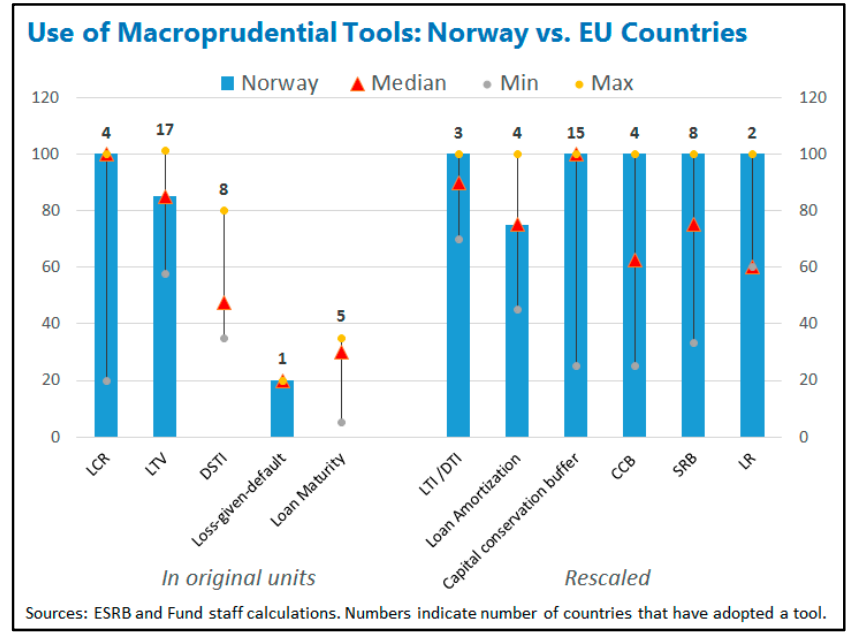

\footnotetext{
${ }^{9}$ In Norway, banks' losses are more likely to accumulate to the corporate (rather than household) portfolios, given that: (i) households have sound repayment buffers in view of their high and strengthened financial asset holdings; (ii) the full recourse nature of mortgages has typically meant that households prioritize mortgage payments over other payments; and (iii) banks' loss absorption capacity is enhanced through LTV regulations.

${ }^{10}$ Banks' direct exposure to oil-related industries is limited, and there are so far few signs of problems with oilrelated industries spilling over into other industries (Figure 5).

11 See Technical Note on Bank Stress Testing for Norway 2015 FSAP Update and NB 2016 Financial Stability Report.

12 Norges Bank's assessment of financial imbalances is based on the credit-to-GDP ratio, developments in property prices, and banks' wholesale funding ratio.
} 
mid-2018) introduced a DTI limit of five times the borrower's gross annual income to complement the LTV limit and affordability tests, tightened the condition for applying an amortization requirement, and lowered the LTV limit for purchasing a second home and the speed limit for Oslo; ${ }^{13}$ and (iii) banks will be subject to a leverage ratio requirement of 5 percent (with an exception for DNB - the largest bank - at 6 percent) from 30 June 2017. In addition, the FSA has submitted a proposal-currently under consultation - to introduce liquidity coverage ratio (LCR) requirements in significant currencies. Supervision has focused on banks' risk management and underwriting standards in the CRE sector, and applied capital add-ons on banks with high loan portfolio concentration on CRE.

\section{Nevertheless, further targeted macroprudential measures should be considered.}

Additional targeted measures could help contain systemic risks if vulnerabilities in the housing sector intensify, including: tighter LTV limits, a lower speed limit, and/or higher mortgage risk weights. Deployment of macroprudential tools to contain banks' CRE exposures, such as LTV limits, and/or a sectoral CCB, should be biased to being ahead of the curve. In addition, existing data gaps are important to fill in parallel with improving analysis of CRE valuations.

\section{In the longer term, the macro-financial resilience of the economy to housing market} shocks should be enhanced through tax and housing market reform. Reducing the generous tax preferences for housing investment would help prevent excessive leverage and dampen housing cycles. ${ }^{14}$ Moreover, policies such as mortgage interest deductibility also tend to be regressive and may crowd out capital from more productive investments than housing, resulting in efficiency losses. The current low interest rate environment limits the effective benefit of interest deductibility and provides a good opportunity to start reducing mortgage interest deductibility. A more developed rental market would help relieve demand pressures as well as support labor mobility across regions as the economy goes through structural changes. ${ }^{15}$ While recent streamlining of building codes-which shortened the time needed for obtaining a building permit and finishing construction-is welcome, relaxing remaining constraints on new property construction, including at the municipal level, could boost the supply of housing, thereby mitigating house price growth.

\footnotetext{
13 The speed limit allows ten percentage of volume of new mortgage loans to deviate from one or more of new residential mortgages requirements relating to affordability tests, LTV ratios, and principal payments. The limit for Oslo has been recently reduced to eight percent.

${ }^{14}$ See Chapter 1 of the Selected Issues as well as Arnold, N. \& Nan Geng, 2015, "The Housing Boom and Macroprudential Policy," Norway Selected Issues, IMF Country Report No. 16/215.

15 The rental market in Norway is relatively unregulated but limited in size, with private and public rental combined accounts for about 23 percent of the total dwelling stock, compared to an average of 38 percent for other Nordic countries.
} 
Current Mortgage Interest Deductibility from Personal Income Taxes

\begin{tabular}{|c|c|c|c|c|c|c|c|c|}
\hline & Denmark & Finland & Ireland & Netherlands & Norway & Spain & Sweden & United Kingdom \\
\hline General rule & 32.7 percent & $\begin{array}{c}45 \text { percent capital } \\
\text { income deduction } \\
\text { in 2017; } 35 \text { percent } \\
\text { in 2018; } 25 \text { percent } \\
\text { in } 2019 \text { and } \\
\text { thereafter }\end{array}$ & $\begin{array}{l}\text { Until 2017: Up to } \\
30 \text { percent for first- } \\
\text { time homebuyers, } \\
\text { and up to } 15 \\
\text { percent for others. } \\
2018 \text { and onward: } \\
0 \text { percent }\end{array}$ & $\begin{array}{l}100 \text { percent for pre- } \\
2013 \text { loans; } 100 \\
\text { percent for post- } \\
2013 \text { fully } \\
\text { amortizing loans } \\
\text { (within } 30 \text { years) }\end{array}$ & $\begin{array}{c}100 \text { percent (full } \\
\text { deduction) }\end{array}$ & $\begin{array}{c}0 \text { percent for } \\
\text { properties } \\
\text { purchased after Jan } \\
1,2013\end{array}$ & 30 percent & 0 percent \\
\hline Caps/notes & $\begin{array}{l}\text { Reduced to } 27 \\
\text { percent in } 2017 \text { for } \\
\text { annual mortgage } \\
\text { interest expense } \\
\text { over DKK } 50,000 ; \\
26 \text { percent in } 2018 \text {; } \\
25 \text { percent in } 2019 \\
\text { and thereafter }\end{array}$ & $\begin{array}{l}30 \text { percent } \\
\text { deduction of the } \\
\text { excess interest } \\
\text { expense over } \\
\text { capital income } \\
\text { against income tax, } \\
\text { up to EUR } 1,400 \\
\text { per year ( } 32 \\
\text { percent for first- } \\
\text { time homebuyers) }\end{array}$ & $\begin{array}{c}\text { Deductibility varies } \\
\text { by origination date } \\
\text { (only 2004-12), and } \\
\text { borrower's marital } \\
\text { status }\end{array}$ & $\begin{array}{l}\text { The maximum tax } \\
\text { rate at which } \\
\text { mortgage interest } \\
\text { can be deducted } \\
\text { decreases by } 0.5 \\
\text { points per year } \\
\text { from } 52 \text { percent in } \\
2013 \text {, to } 38 \text { percent } \\
\text { in } 2042 \text { ( } 50 \text { percent } \\
\text { in 2017) }\end{array}$ & & $\begin{array}{l}15 \text { percent } \\
\text { deduction up to } \\
\text { EUR } 9,040 \text { per year, } \\
\text { for properties } \\
\text { purchased before } \\
\text { Dec } 31,2012\end{array}$ & $\begin{array}{c}\text { Reduced to } 21 \\
\text { percent for annual } \\
\text { mortgage interest } \\
\text { expense over SEK } \\
100,000\end{array}$ & $\begin{array}{l}\text { Mortgage interest } \\
\text { relief at source } \\
\text { abolished in } 2000\end{array}$ \\
\hline
\end{tabular}

32. The recently-concluded MoUs between the Nordic supervisors and the ECB on the supervision, liquidity support, and resolution of systemically-important branches have strengthened the basis for regional cooperation on financial stability issues. This is particularly important in view of Nordea's conversion of its Norwegian subsidiary-the second largest bank in Norway-into a branch in early 2017.

\section{Further efforts are needed to address several key FSAP recommendations that remain} outstanding (Annex III), including: (i) limiting banks' wholesale funding including on the mismatch between the maturity of currency swaps and underlying exposures; (ii) enhancing the FSA's de jure operational independence; and (iii) strengthening the legal and institutional framework for crisis management, safety nets, and bank resolution.

\section{Authorities' Views}

34. The authorities generally agreed with staff's assessment. They are alert to the risks from rising house prices and household debt from already high levels. They observed that, while it is still early to evaluate the effectiveness of the recently tightened mortgage regulations, banks have tightened their lending standards and there are early signs of a slowdown of house price inflation. In addition, housing supply has recently been catching up due to increased house prices and as streamlining of building regulations during the past two years has shortened the time to obtain a building permit and the time to build. The Norwegian authorities acknowledge that owner-occupied housing is favored both as regards the income tax and as regards the wealth tax. Home ownership is deeply rooted in Norway, and the Government does not want to change that. Hence, the Government has no plans for phasing out the deductibility of mortgage interest. The FSA is monitoring CRE developments closely. The FSA is considering the need for prudential measures related to CRE lending. A thematic in-depth study on CRE-lending by FSA is planned for 2018 , and a stress in the commercial property market will be included in FSA's stress tests going forward. 


\section{Structural Policy: Restoring Competitiveness, Facilitating the Transition, and Raising Growth Potential}

\section{Continued wage restraint and productivity growth are crucial to restoring Norway's} cost competitiveness. Although the krone depreciation during 2013-15 helped regain some lost ground, Norway's cost competitiveness has deteriorated over the past two decades compared to peers due to stagnant productivity and rapid wage inflation (Figure 4). Wage growth has slowed dramatically in recent years, primarily reflecting the flexibility of wage settlement system. Continued wage restraint and reforms to raise labor productivity growth are pivotal to reverse past erosion of capacity in the manufacturing sector and improve Norway's ability to compete in existing and new export markets.

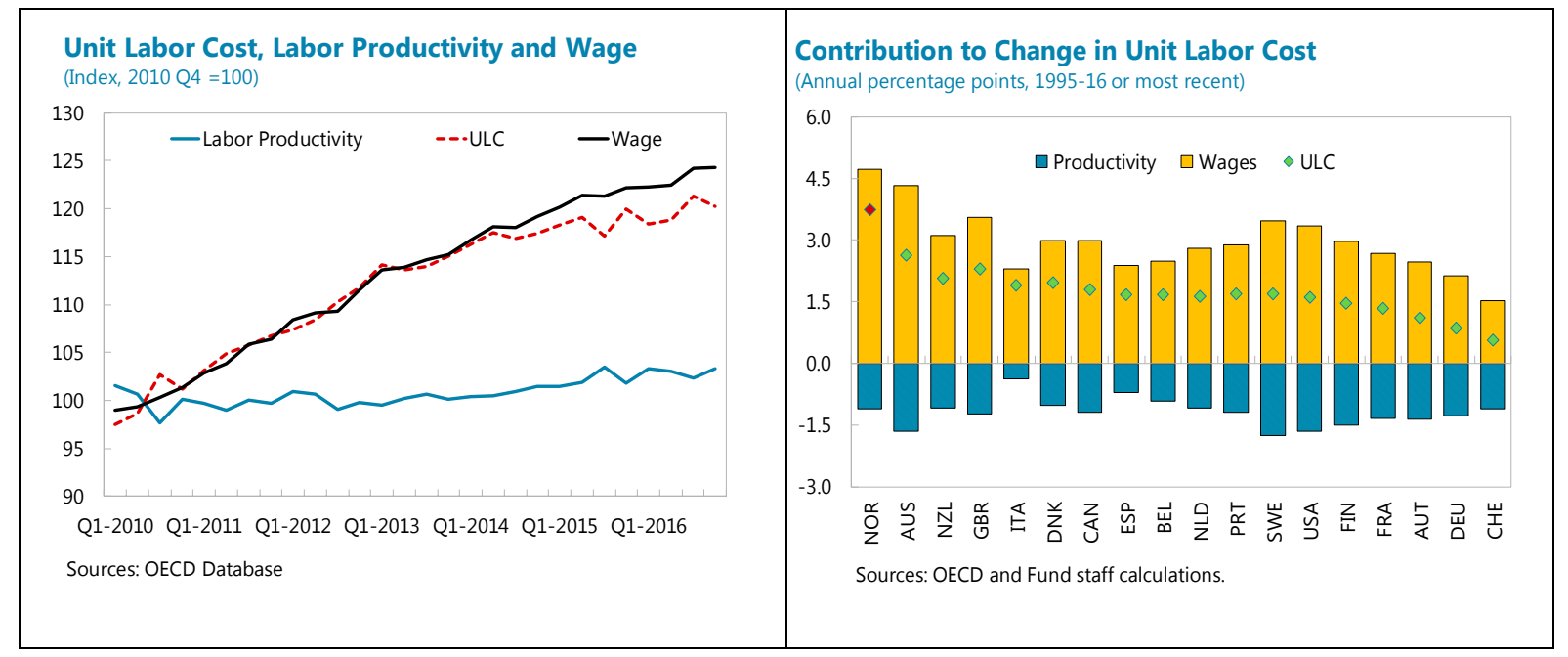

36. Promoting innovation and expanding product market reforms in targeted areas could boost productivity growth. Norway has experienced significant declines in productivity growth since the mid-2000s. The Productivity Commission report highlighted several key reform recommendations to boost productivity, which would reduce structural gaps identified by the OECD and IMF (see Text Table 2). ${ }^{16}$ These include reducing restrictive regulations and cutting aid to unprofitable industries, enhancing cooperation between higher education and industry, relaxing regulations on working hours, making social security benefits more activity oriented, providing support for entrepreneurship and innovation, and reforming local government. Several reforms are underway, including to boost quality of vocational and higher education, and to enhance work incentives in the disability and sickness benefit systems. The authorities should continue with the ongoing reforms, and prioritize and implement further measures to narrow structural gaps.

\section{A successful transition and longer-term growth also hinges on policies underpinning} high-quality employment in the face of aging. While Norway has overall high labor force

\footnotetext{
${ }^{16}$ See IMF Country Report No. 16/215.
} 
participation, it is important to continue to improve work incentives and employability of various groups:

- Women. Norway does well in integrating females into the labor force, but more could be done, especially to increase incentives to expand working hours. The tax system takes care not to explicitly penalize two-earner households, but its progressiveness can nonetheless create disincentives to expanding working hours. Duration of parental leave strikes an adequate balance between supporting families and maintaining caregivers' ties to the labor market and childcare provision has been expanded notably in recent years. However, potential remains to increase care options for the youngest children and to make childcare hours more flexible. ${ }^{17}$ Women also continue to be considerably less represented in management roles, including in the public sector.

- Men, immigrants, and youth. These groups have been hit harder by the global crisis and the 2014-15 oil price slump. Labor market and other policies should be geared toward correcting incentives and facilitating labor reallocation across sectors and regions. Disability rates remain exceptionally high and eligibility requirements are still lax compared with peer countries, despite recent incremental reforms. Further tightening eligibility checks on sickness and disability benefits and making unemployment benefits more activity oriented would support labor participation. ${ }^{18}$ Targeted active labor market policies (ALMP) and lifelong learning opportunities could be further enhanced to improve search and matching efficiency. Further enhancing flexibility in temporary work contracts and wages could be considered to incentivize hiring of new entrants. In addition, promoting affordable housing and related infrastructure in job-abundant urban areas could facilitate labor mobility. Guiding attitudes to encourage more male job-seekers in traditionally female sectors would also be useful. For youth, reforms to improve the quality of the education system are important to enhance their marketable skills and lower dropout rates. For refugees, Norway currently has reasonably efficient integration programs, but efforts could

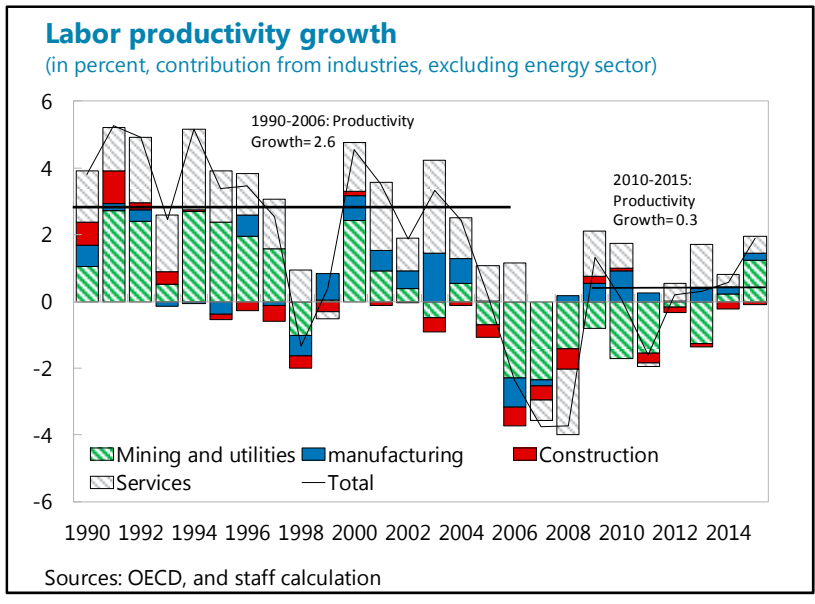
be reinforced to successfully integrate them into productive employment.

\footnotetext{
${ }^{17}$ It could also underpin women's participation in professional activities, where longer absences can carry implicit penalties regarding career progression.

18 Sickness and disability benefits are used by a large share of the population in Norway (greater than 10 percent disability incidence and higher prolonged sickness absence than among peer countries) and used as a pathway of dropping out of the labor force. It is also uncommon in international comparison to rely exclusively on the general practitioner in certifying eligibility without verification by a third party or government agency.
} 
38. Other structural reforms would improve efficiency and provide additional support to growth potential. While the private sector pension reform has been effective in raising labor force participation among the elderly, it will be critical to complete similar reforms to the public sector retirement system. Additionally, government support to the agricultural sector in the form of subsidies, high import tariffs, and exemption from standard competition regulation is substantial; its reduction would free up resources for more effective policies to sustain rural prosperity and lower food prices.

\section{Authorities' Views}

39. The authorities agreed on the importance of measures to underpin competitiveness and labor supply. They noted that competitiveness has further improved due to wage moderation, which is expected to continue this year and should help manufacturing exports expand more strongly in future. They agreed that some of the decline in employment rates over past years is likely due to structural factors, but that an improvement of the economy's cyclical position should buttress employment going forward. Nonetheless, there is concern that certain subgroups, especially the young and immigrants, could continue to struggle. In response, work incentives and activity requirements within social benefits system are being further enhanced; child care is being expanded; education reform continues with a focus on enhancing attainment in science and math; unemployed youth are guaranteed speedy access to ALMPs; and efforts are being made to speed up refugee integration into the labor market. Finally, discussions on public pension reform are expected to be taken up again in the fall of 2017.

\section{STAFF APPRAISAL}

40. The mainland economy is bottoming out from the oil-related downturn and is expected to continue to recover at a modest pace. Stronger domestic demand supported by accommodative fiscal and monetary policies has underpinned a recovery since late 2016 and unemployment has started falling. Inflation expectations remain well anchored despite recent declines in inflation due to low wage growth and earlier krone appreciation. The recovery is expected to continue with improving consumer and business confidence and expanding production. But housing market vulnerability has risen with overvalued and rising house prices and elevated household debt.

\section{Norway's external position is moderately weaker than implied by medium term} fundamentals. While Norway's net international investment position remains strong, the current account position has weakened as oil prices remain low and non-oil tradable exporters continue to face cost competitiveness challenges, especially given moderate appreciation of Norway's real exchange rate during 2016. While there has been some progress in rebalancing economic activity toward the non-oil sector, it remains incomplete. Further structural reforms to improve cost competitiveness and productivity growth would support this economic rebalancing and improve non-oil export performance. 
42. Advancing the economic rebalancing towards a less oil and gas dependent growth model is becoming more urgent. With lower oil prices seemingly the new norm, sustaining longerterm growth will need to rely on boosting non-oil sector activities, which is challenging given low productivity growth, high labor costs, and falling labor force participation rates among immigrants, men, and the young in face of an aging population. Addressing the challenges requires reallocating resources to the non-oil sectors, reviving productivity growth, further improving cost competitiveness, and promoting high-skilled labor supply.

43. The expansionary fiscal stance is broadly appropriate this year, provided the measures are pro-transition. The further fiscal stimulus in 2017 appropriately supports the recovery, with measures to combat unemployment, improve infrastructure and $R \& D$, and implement the tax reform. Given the significant output gap, fiscal policy should remain supportive until the recovery is on a more solid footing, and the stimulus measures should facilitate a smooth economic transition. As growth gathers steam, the fiscal stance should converge to neutral to help contain Dutch Disease effects. The recent tightening of the fiscal rule is welcome as it helps conserve oil revenue to address aging-related fiscal challenges. Further tax reforms should be considered to promote an efficient allocation of resources and sustain longer term growth.

44. Monetary policy should stay accommodative. Given the slack in the economy and weakened inflation outlook, maintaining an accommodative monetary policy stance is appropriate pending a durable recovery. Further easing could be considered in the event of significant downside surprises on growth and inflation. Financial stability concerns arising from a "low for long" interest rate environment warrant great caution, but they should be addressed primarily through macroprudential measures as well as tax and housing market reforms.

45. Significant policy actions have been taken to address financial stability risks, but continued vigilance and further measures are needed. Financial vulnerabilities have increased in the context of overvalued and rising housing prices, increasingly elevated household debt and higher money market premia. Important steps have been taken to cope with the build-up of financial imbalances, including recent decisions to raise the $C C B$, tighten mortgage regulations, and introduce the DTI limit and LR requirements. However, continued vigilance is needed and further targeted measures should be considered if vulnerabilities in the housing sector intensify. The close supervision on banks' risk management and underwriting standards in the CRE sector, as well as efforts to increase CRE risk weights and to apply capital add-ons on banks with high concentration on CRE lending, should continue. Deployment of macroprudential tools to contain banks' CRE exposures, such as loan-to-value (LTV) limits and/or a sectoral CCB, should be biased to being ahead of the curve. Moreover, macroprudential policies should be reinforced by tax and housing market reforms, including reducing tax preferences for housing, relaxing constraints on new property construction, and developing the rental market. The authorities should also implement the liquidity coverage ratio requirements in significant currencies-currently under consideration-and continue to enhance stress tests for banks to take account of funding risks.

46. A successful economic transition hinges on continued structural reforms. Wage restraint and labor market reforms should continue to improve cost competitiveness, facilitate 
economic rebalancing, and support labor supply. Reviving the growth engine in the non-oil sector also hinges on promoting high-quality employment and boosting productivity through reforms to education, innovation, and product market regulations. In addition, further reforms to the publicsector pension system and sickness and disability benefits will help promote labor force participation. There is also scope for efficiency gains from lowering the level of protection and subsidies for agriculture.

It is proposed that the next Article IV consultation with Norway be held on the standard 12month cycle. 


\begin{tabular}{|c|c|}
\hline \multicolumn{2}{|r|}{$\begin{array}{l}\text { Box 1. Risk Assessment Matrix }{ }^{1} \\
\text { Potential Deviations from Baseline }\end{array}$} \\
\hline Source of Risks and Relative Likelihood & Expected Impact if Risk is Realized \\
\hline \multicolumn{2}{|r|}{ Downside Risks } \\
\hline \multirow{2}{*}{$\begin{array}{l}\text { Low } \\
\text { Lower energy prices. Production cuts by OPEC } \\
\text { and other major producers may not materialize as } \\
\text { agreed while other sources of supply could } \\
\text { increase production. }\end{array}$} & $\begin{array}{l}\text { High } \\
\text { Lower energy prices could weigh on economic recovery through a further reduction in the oil } \\
\text { related demand for mainland goods and services. }\end{array}$ \\
\hline & $\begin{array}{l}\text { Policy response: Allow automatic stabilizers to fully operate and/or use remaining monetary } \\
\text { space to support the recovery. Make further progress on labor market and productivity- } \\
\text { enhancing reforms, and apply temporary expenditure measures that are pro-transition. }\end{array}$ \\
\hline \multirow{2}{*}{$\begin{array}{l}\text { Weaker-than-expected global growth: } \\
\text { Significant China slowdown and its spillovers } \\
\text { Low/Medium } \\
\text { Structurally weak growth in key advanced and } \\
\text { emerging economies High/Medium }\end{array}$} & $\begin{array}{l}\text { High } \\
\text { Global growth slowdown could lower external demand and inhibit the recovery of non-oil } \\
\text { exports, resulting in lower output and higher unemployment. }\end{array}$ \\
\hline & $\begin{array}{l}\text { Policy response: Allow automatic stabilizers to fully operate and/or use remaining monetary } \\
\text { space to support the recovery. Make further progress on labor market and productivity- } \\
\text { enhancing reforms, and apply temporary expenditure measures that are pro-transition. }\end{array}$ \\
\hline \multirow{2}{*}{$\begin{array}{l}\text { Medium/ High } \\
\text { Widespread and large reduction in house } \\
\text { prices: } \\
\text { House price and household debt keeps rising } \\
\text { from high levels, posing higher risk of sharp } \\
\text { correction of overvaluation. }\end{array}$} & $\begin{array}{l}\text { High } \\
\text { Substantial falls in house prices could dampen private consumption and reduce } \\
\text { corporate earnings, creating negative spillover effects on banks' balance sheets. }\end{array}$ \\
\hline & $\begin{array}{l}\text { Policy response: Take additional preemptive and targeted macroprudential measures and } \\
\text { reduce tax preferences on home ownership. In response to the shock, countercyclical buffer can } \\
\text { be reduced and monetary policy eased further to mitigate a possible credit crunch and contain } \\
\text { spillovers to the macro-economy. }\end{array}$ \\
\hline \multirow[t]{2}{*}{ Financial conditions: } & $\begin{array}{l}\text { Medium } \\
\text { Re-emergence of bank stress could strain liquidity given banks' wholesale funding dependence. }\end{array}$ \\
\hline & $\begin{array}{l}\text { Policy response: Re-double efforts to reach new economic cooperation and trade agreements } \\
\text { to minimize disruptions and, be prepared to supply liquidity in case of a liquidity crunch. }\end{array}$ \\
\hline \multirow{2}{*}{$\begin{array}{l}\text { Medium } \\
\text { Stalled progress on economic transition to a } \\
\text { less oil-dependent growth model, if wages fail } \\
\text { to adjust and productivity remains stagnant in } \\
\text { the non-oil sector. }\end{array}$} & $\begin{array}{l}\text { Medium } \\
\text { Permanent decline of potential growth as the non-oil sector fails to pick up slack } \\
\text { from the persistently lower oil prices and investment. }\end{array}$ \\
\hline & $\begin{array}{l}\text { Policy response: Facilitate the resource shift to non-oil sectors. Adopt reforms to improve cost } \\
\text { competitiveness, stimulate innovation and promote investment. }\end{array}$ \\
\hline \multirow{2}{*}{$\begin{array}{l}\text { High } \\
\text { Ineffective integration of immigrants and } \\
\text { refugees to productive employment. }\end{array}$} & $\begin{array}{c}\text { High } \\
\text { Ineffective integration could weigh on medium to long-term growth and the public finances. }\end{array}$ \\
\hline & $\begin{array}{l}\text { Policy response: Take policy actions to support the integration of migrants into the labor force, } \\
\text { e.g., strengthening refugees' access to ALMPs and accelerating the settlement process. }\end{array}$ \\
\hline \multirow[t]{2}{*}{$\begin{array}{l}\text { High } \\
\text { Policy and geopolitical uncertainties associated } \\
\text { with negotiating post-Brexit arrangements and } \\
\text { with upcoming major elections. }\end{array}$} & $\begin{array}{l}\text { Low } \\
\text { - If euro area and U.S. financial markets are effected, this could lead to higher costs and } \\
\text { liquidity strains for Norwegian banks that rely on wholesale funding. } \\
\text { - Higher trade barriers could dampen exports and investment and hurt growth outlook. }\end{array}$ \\
\hline & $\begin{array}{l}\text { Policy response: Re-double efforts to reach new economic cooperation and trade agreements } \\
\text { to minimize disruptions and, be prepared to supply liquidity in case of a liquidity crunch. }\end{array}$ \\
\hline \multirow{3}{*}{$\begin{array}{l}\text { Low } \\
\text { Stronger than expected recovery of the } \\
\text { Norwegian economy. }\end{array}$} & Upside Risks \\
\hline & $\begin{array}{l}\text { Medium } \\
\text { and business confidence and global demand, especially in the context of accommodative } \\
\text { macroeconomic policies. }\end{array}$ \\
\hline & Policy Response: Roll back fiscal stimulus if signs of overheating emerge. \\
\hline \multirow{2}{*}{$\begin{array}{l}\text { Low } \\
\text { Higher than expected petroleum } \\
\text { investment, if oil prices appreciate more than } \\
\text { projected, and cost-reduction measures lower } \\
\text { development costs further. }\end{array}$} & $\begin{array}{l}\text { Medium } \\
\text { Petroleum investment would expand as projects become more profitable, which leads to higher } \\
\text { oil exports and growth. }\end{array}$ \\
\hline & $\begin{array}{l}\text { Policy Response: Roll back fiscal stimulus and retain wage restraint, labor market, and } \\
\text { productivity-enhancing reforms to diversify the economy. }\end{array}$ \\
\hline \multicolumn{2}{|c|}{$\begin{array}{l}{ }^{1} \text { The Risk Assessment Matrix (RAM) shows events that could materially alter the baseline path (the scenario most likely to materialize in the view of IMF staff). The relative } \\
\text { likelihood of risks listed is the staff's subjective assessment of the risks surrounding the baseline ("low" is meant to indicate a probability below } 10 \text { percent, "medium" a } \\
\text { probability between } 10 \text { and } 30 \text { percent, and "high" a probability of } 30 \text { percent or more). The RAM reflects staff views on the source of risks and overall level of concern as of } \\
\text { the time of discussions with the authorities. Non-mutually exclusive risks may interact and materialize jointly. }\end{array}$} \\
\hline
\end{tabular}




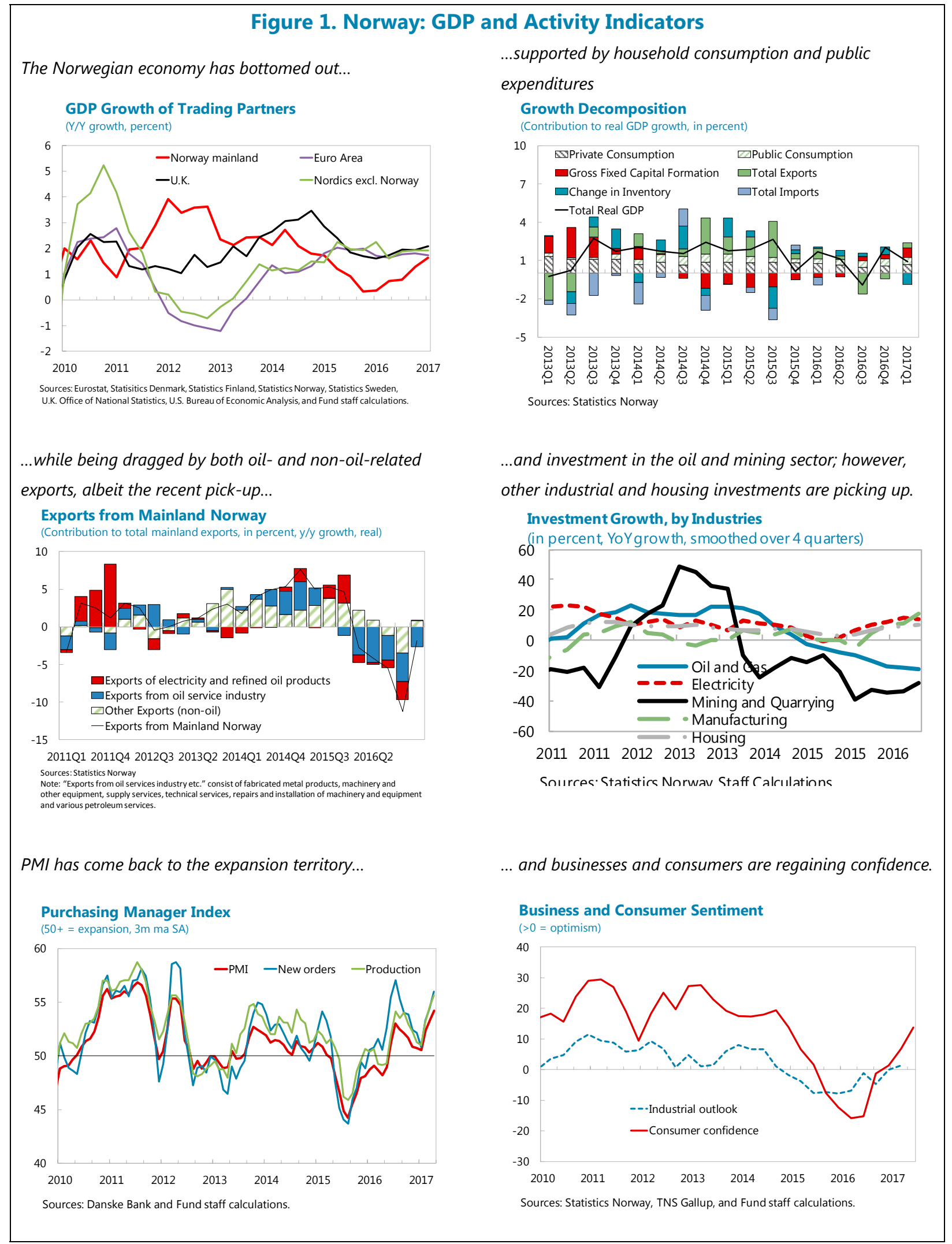


Figure 2. Norway: Labor Market Developments

Employment growth has levelled off since late 2014.

Labor Force, Employment, and Total Hours Worked (4-quarter moving average)

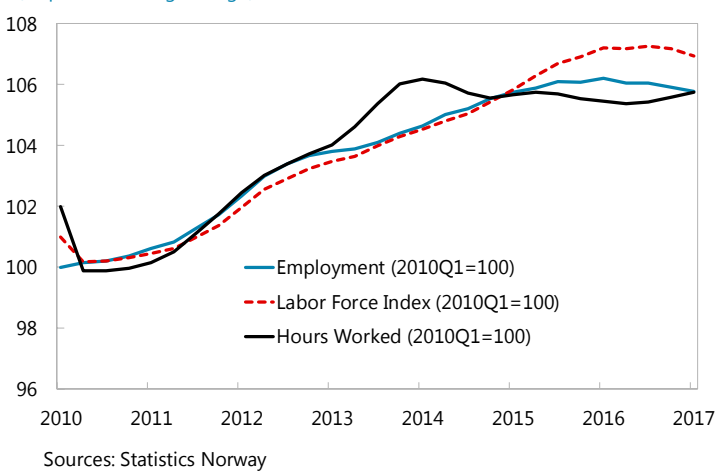

Also, male employment rates have declined and not recovered after the global crisis.

Male employment rate, 2015

口 Level (Percent) $\diamond$ Change vs 2000 (Percentage points, RHS)

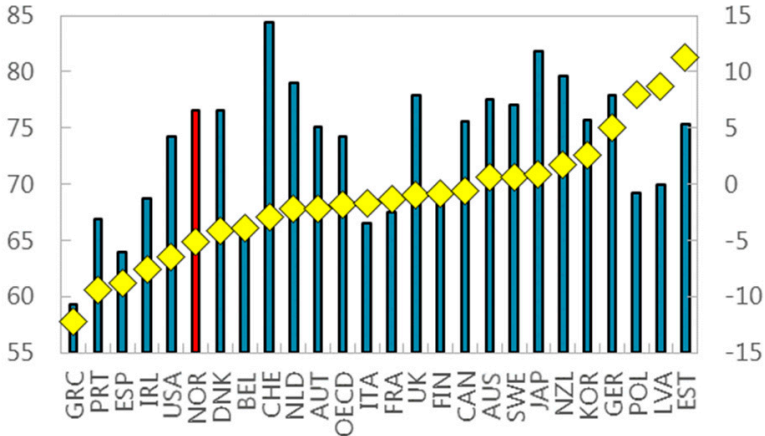

Integrating immigrants, particularly non-western ones, into the labor market remains a challenge despite recent progress.

Employment Rates

(Percent of population 15-74 years old)

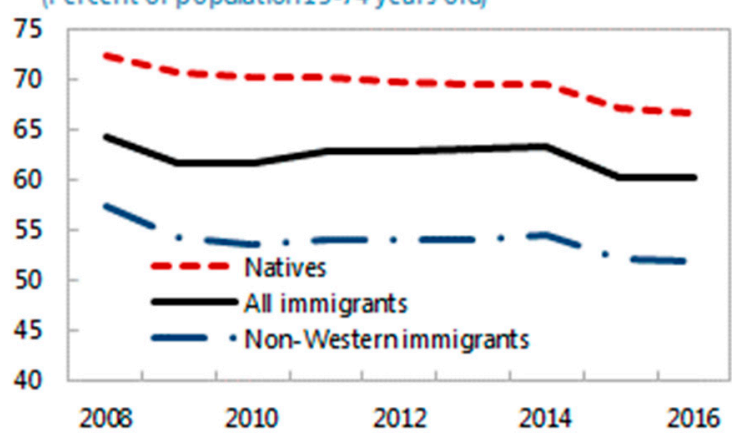

Sources: Statistics Nonway and Fund staff calculations.

Notes: Non-Western immigrants excludes immigrants from EU/EFTA, North America, Australia, and New Zealand.
Unemployment seems to have peaked but is considerably higher among men.

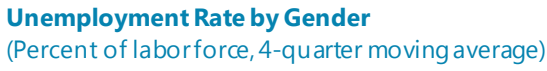

Unemployment Rate by Gender

(Percent of labor force, 4-quarter moving average)

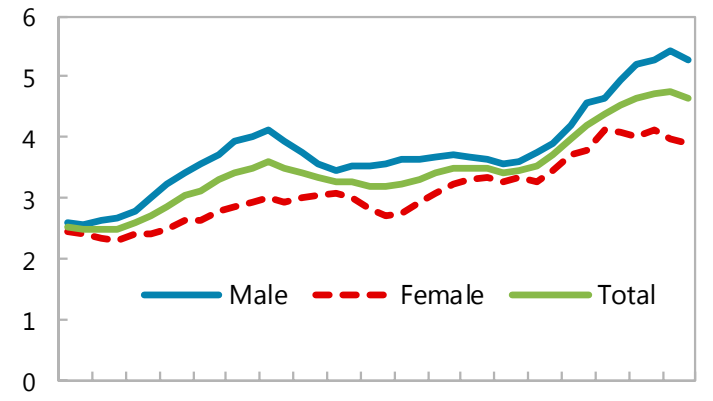

2007Q4 2009Q2 2010Q4 2012Q2 2013Q4 2015Q2 2017Q1

Thus, employment rates between genders have become more equal, despite female employment not advancing. Male-Female gap in employment rate by age (Percentage points)

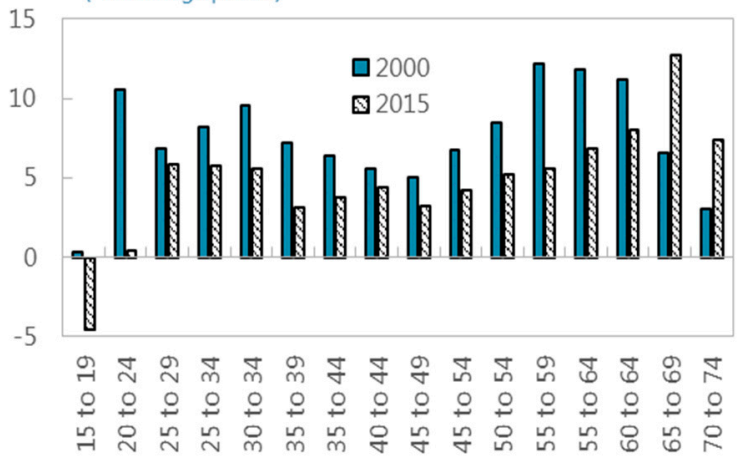

The same is true for young workers.

Labor Market Indicators for Young People (15-24 years old)

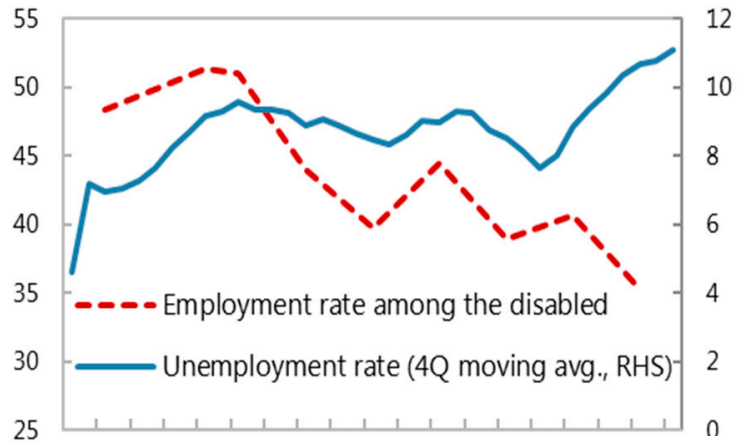

2007Q4 2009Q2 2010Q4 2012Q2 2013Q4 2015Q2 2017Q1 


\section{Figure 3. Norway: Price Developments}

Both headline and core inflation have started to fall since mid-2016...

Annual Inflation

(Percent change)

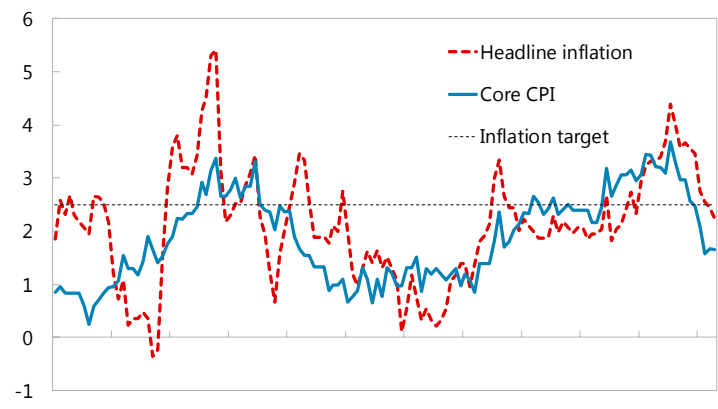

$\begin{array}{llllllllllll}2006 & 2007 & 2008 & 2009 & 2010 & 2011 & 2012 & 2013 & 2014 & 2015 & 2016 & 2017\end{array}$ Sources: Statistics Norway and Fund staff calculations.

...and domestic producer price inflation trended down...

Producer Price Index: Consumer Goods

(Y/Y percent change)

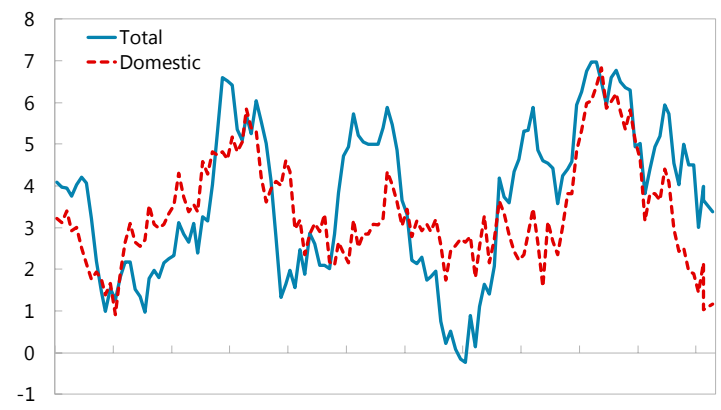

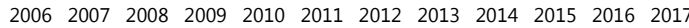

Sources: Statistics Norway and Fund staff calculations.

...and soft labor market conditions.

Wage Growth and Unemployment Rate (Percent)

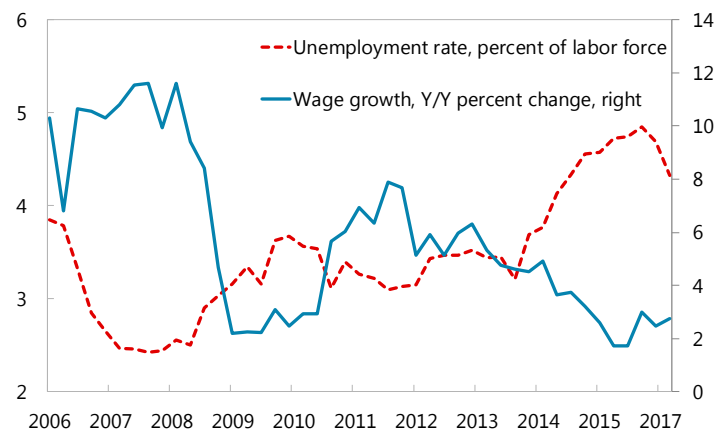

Sources: Statistics Norway and Fund staff calculations. ...as exchange rate developments feed through prices of imported consumer goods.

Exchange Rate and Imported Price

( $\mathrm{Y} / \mathrm{Y}$ percent change)

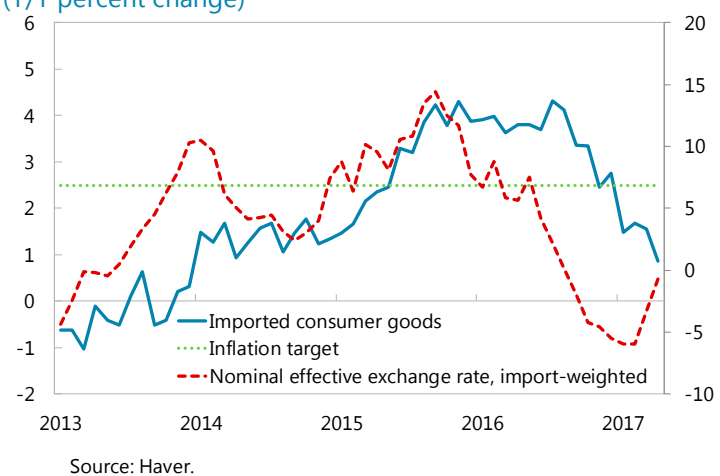

...amid overall low capacity utilization rate...

Inflation and Capacity Utilization Rate (Percent)

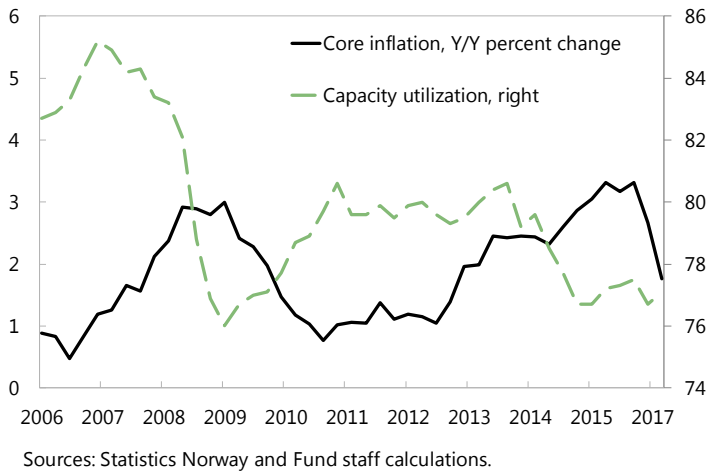

Nonetheless, inflation expectations remain well anchored.

Survey-Based Inflation Expectations

(Percent)

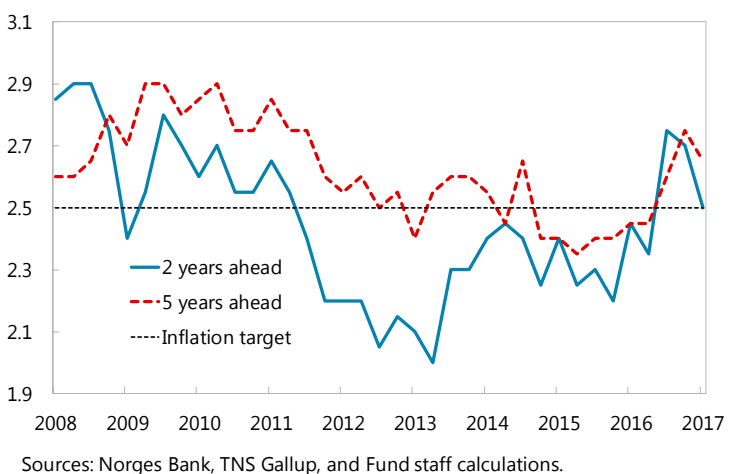


Figure 4. Norway: External Sector Developments

Norway's current account narrowed further in 2016, driven by the declining oil trade balance.

Current Account with Oil and Non-oil Export Components (Percent of GDP)

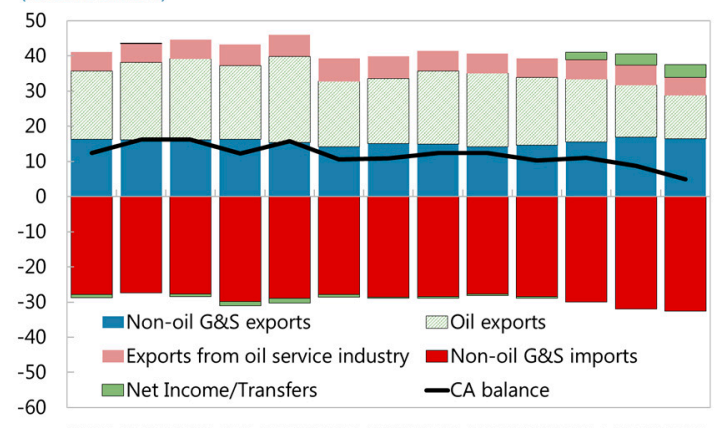

2004200520062007200820092010201120122013201420152016

Sources: Statistics Norway and Haver.

... the low oil prices have put pressure on the oil trade surplus.

\section{Oil and Gas Prices}

(U.S. Dollars)

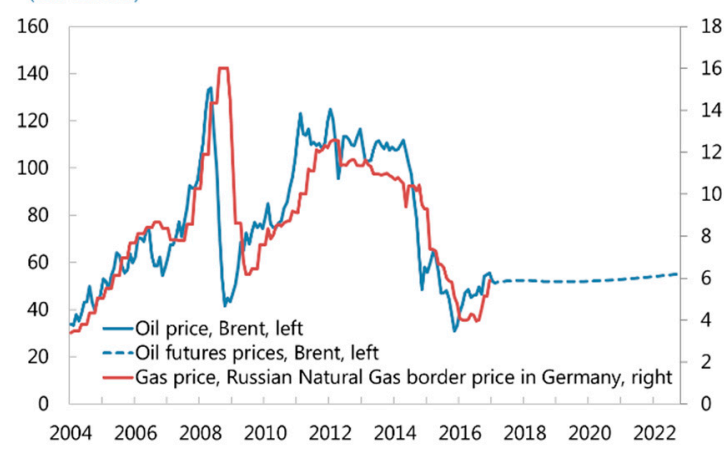

Sources: IMF Global Economic Assumptions and Fund staff calculations.

Krone depreciation halted in early 2016 and has been partly reversing since then.

\section{Effective Exchange Rates}

(Index: January $1995=100$ )

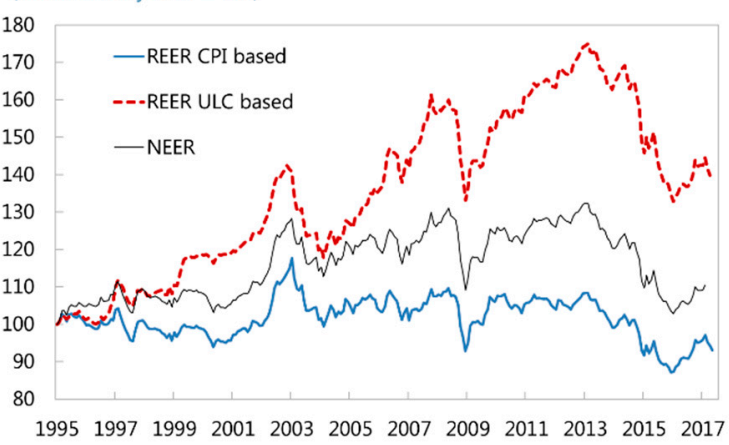

199519971999200120032005200720092011201320152017
Sources: IMF World Economic Outlook, Information Notice System and Fund staff
While volume of petroleum production has been stable and is expected to remain so, ...

Petroleum production

(Million cubic meter oil equivalents)

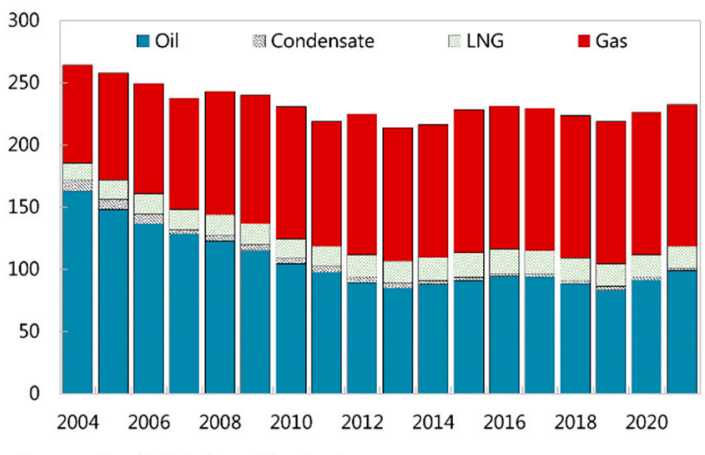

Sources: Nordic Petroleum Directorate.

While aquaculture and tourism exports kept increasing, manufacturing exports remain sluggish partly due to capacity constraints and some temporary factors.

Non-oil goods and services exports by product group (NOK billions, 4-quarter moving average)

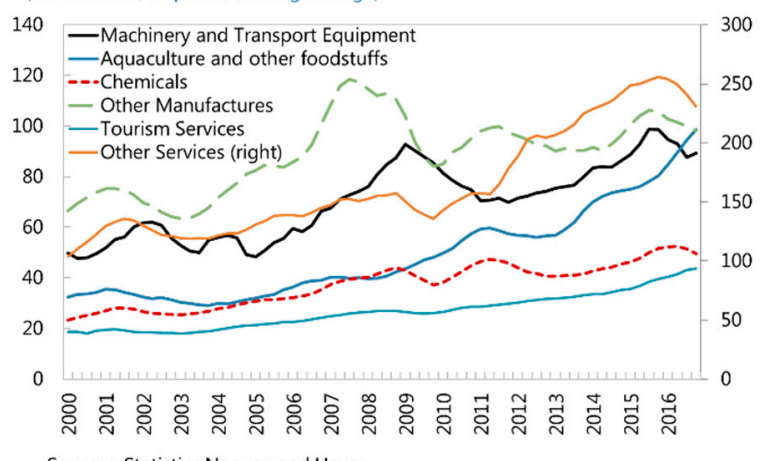

Sources: Statistics Norway and Haver.

Regaining the rest of the lost ground in competitiveness remains a challenge.

Unit Labor Costs

(Index: $1995=100$ )

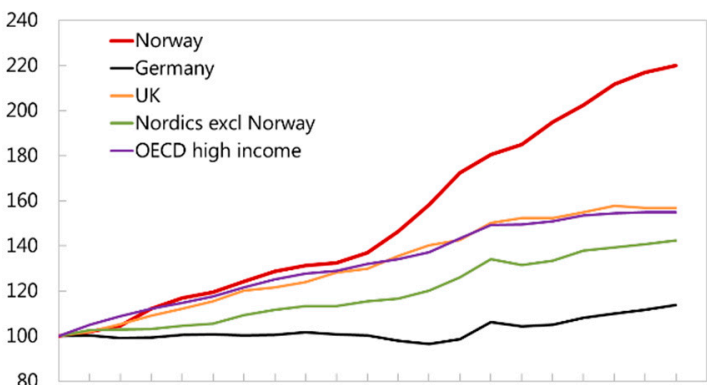

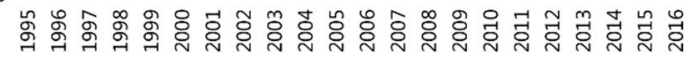
Sources: $O E C D$ and Fund staff calculations. 


\section{Figure 5. Norway: Credit Developments}

Despite the recent pick-up, real interest rates remain low.

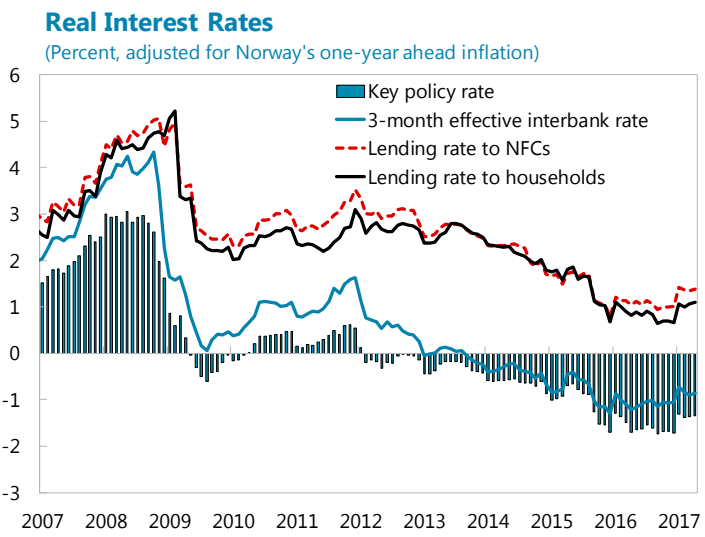

The slight slowdown in corporate credit growth is broadbased except for the construction industry.

Credit to Nonfinancial Corporations ( $Y / Y$ percent change)

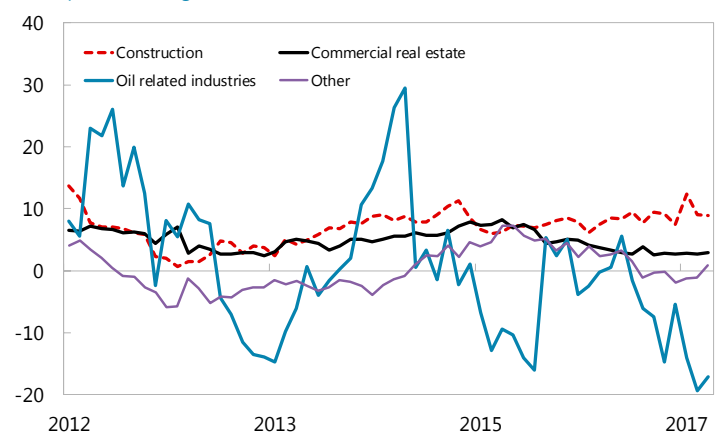

Sources: Norges Bank and Fund staff calculations.

The share of new mortgage lending with a LTV of 85 percent or higher has declined, but that failed the affordability test has increased.

Share of Aproved Mortgage Loans with Risky Loan Terms (Percent)

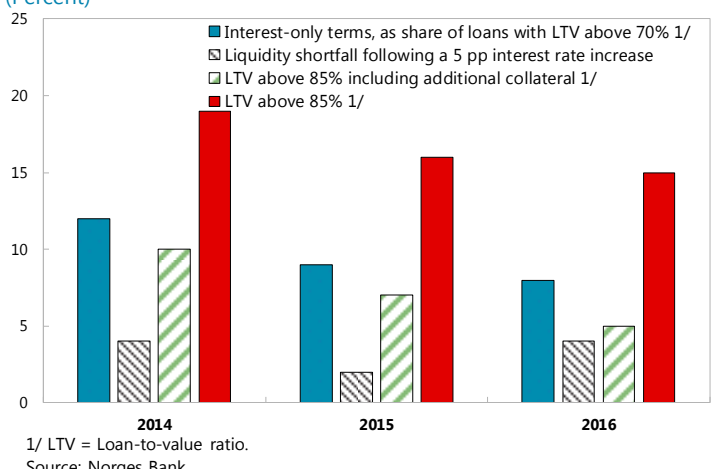

Household credit growth remains largely unchanged whereas that for corporates kept falling...

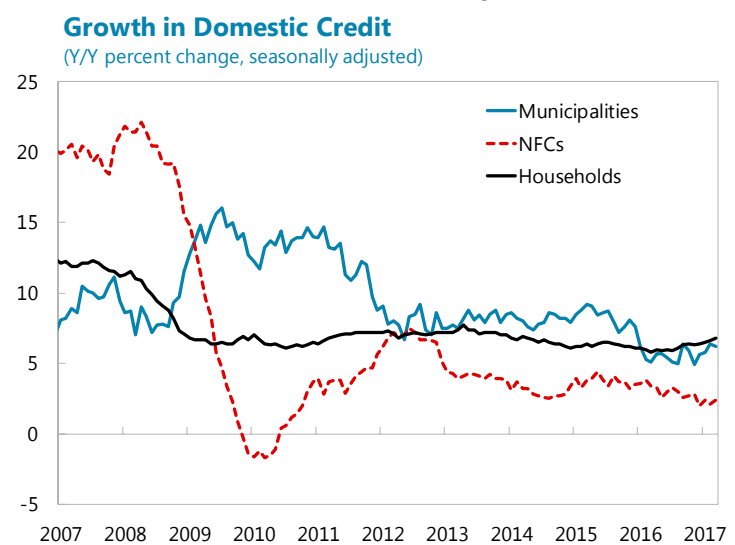

As a result, lending is increasingly concentrated in housing.

Structure of Credit

(Percent of total loans extended by banks and mortgage companies)

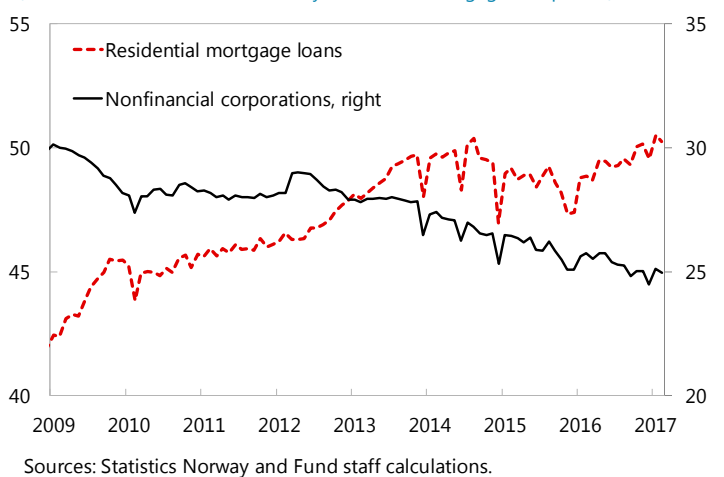

While direct credit exposure to oil-related industries is limited, but corporate lending comprises of considerable CRE exposures.

Corporate Lending by Borrower Industries (Percent of total, 2017M1)
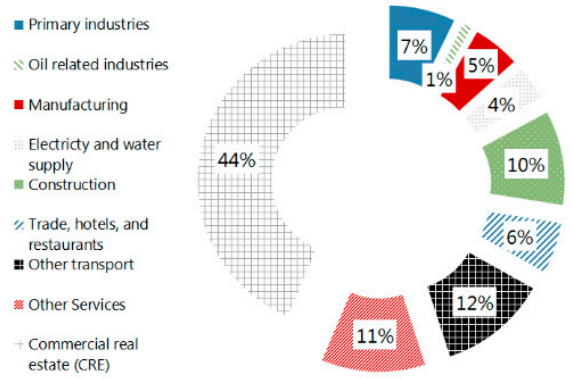

Sources: Statistics Norway and Fund staff calculations 
Figure 6. Norway: Household Sector Developments

House price inflation accelerated sharply in $2016 \mathrm{H} 2$...

House Price Growth

(YN percent change)

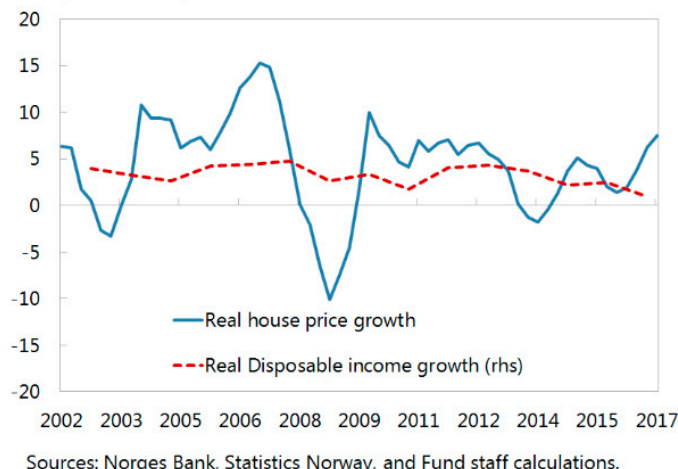

Sources: Norges Bank, Statistics Norway, and Fund staff calculations.

The elevated household debt is among the highest in OECD countries and recently rose to about 227 percent of disposable income.

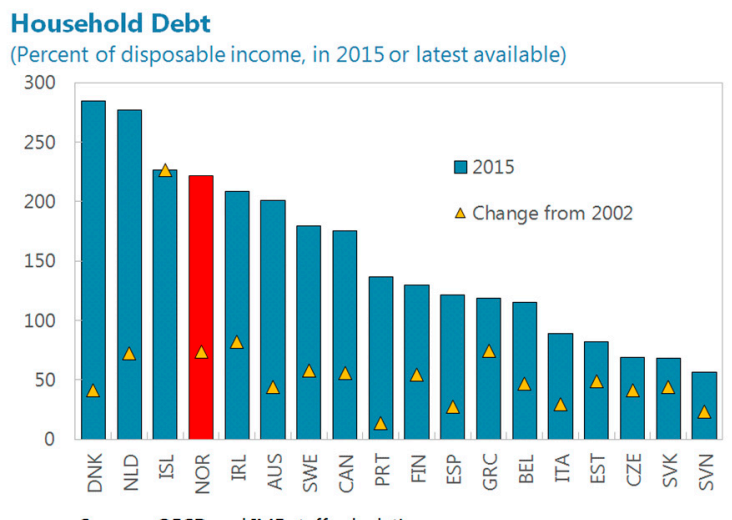

Moreover, debt is skewed toward younger households with limited liquid assets, ...

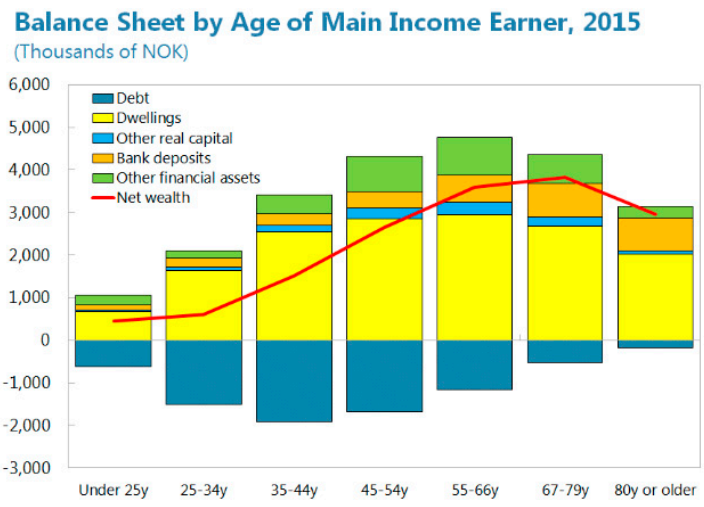

Sources: Norges Bank and Fund staff calculations.
... in most parts of the country, particularly the Oslo area.

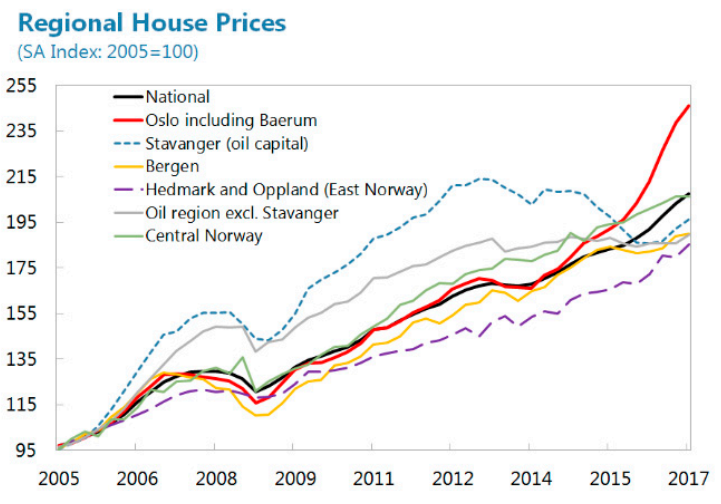

Sources: Statistics Norway, Haver Analytics and Fund staff calculations.

While interest burden remains low and households' net financial assets also strengthened, debt service ratio edged up slightly.

Household Financial Position

(Percent of disposable income)

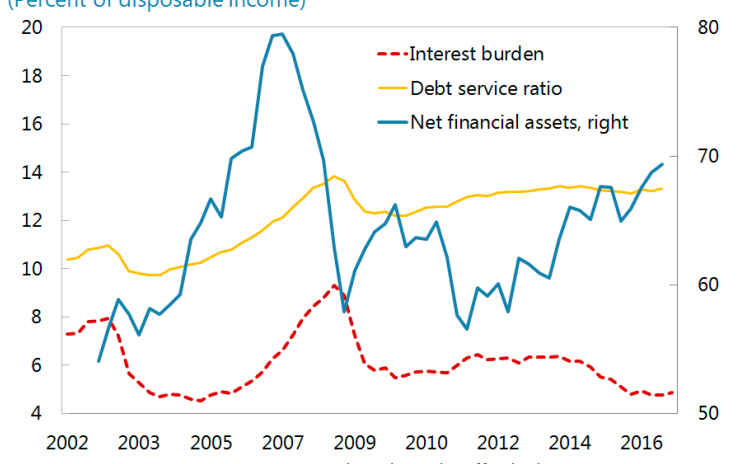

Sources: Statistics Norway, Norges Bank and Fund staff calculations.

... and the share of households with a DTI ratio higher than

5 has kept rising since 2000, with these households mostly residing in urban areas where house prices are high.

Share of Households with DTI $>5$

(Percent, 1987-2014)

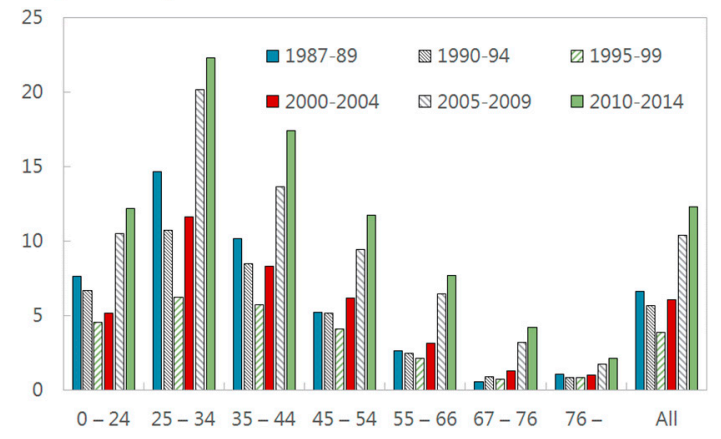

Sources: Statistics Norway and Norges Bank. 


\section{Figure 7. Norway: Corporate Sector Developments}

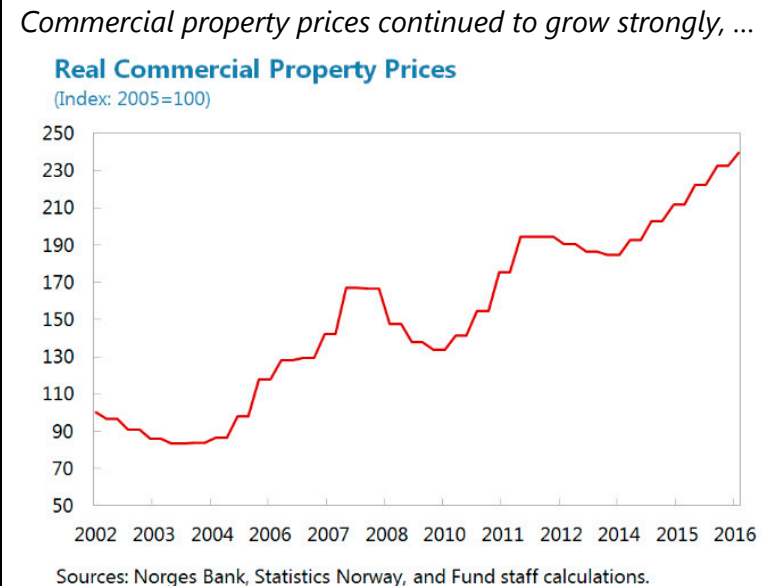

... and the PTR ratio is now above the historical average.

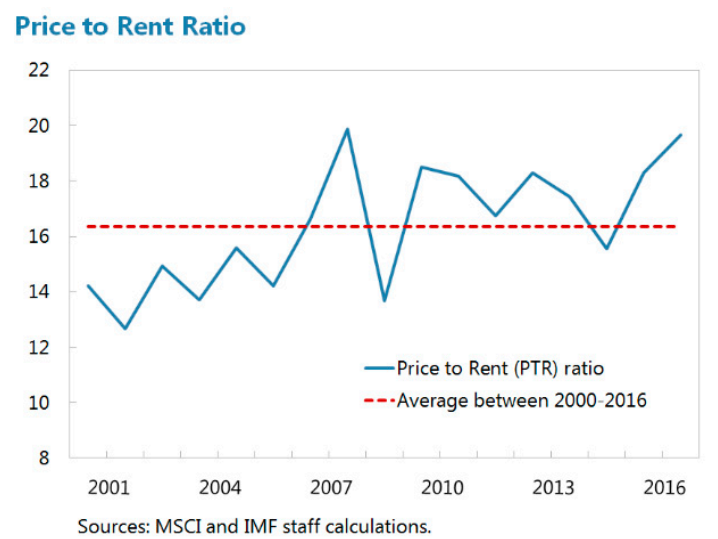

Signs of CRE overvaluation have emerged as the PTR ratio is closer to pre-crisis maximum than in most other peers.

\section{Price to Rent Ratio}

(\% deviation from historical mean, max and min during 2000Q1 to $2016 Q 4$ or latest available)

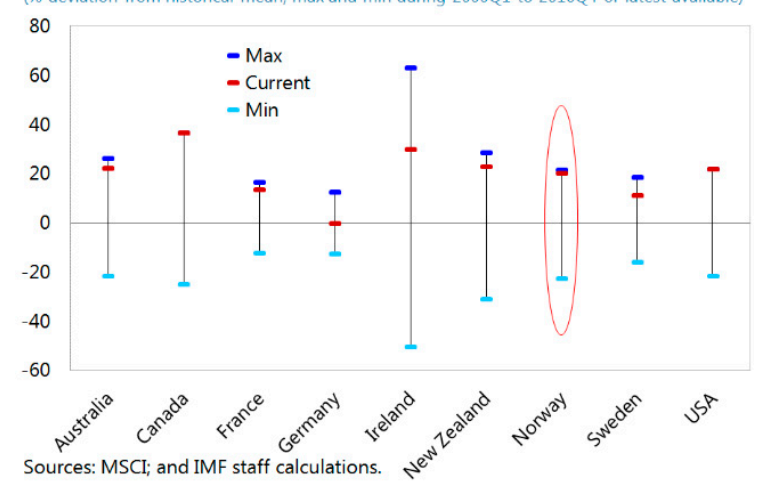

Yet Norway's CRE capital expenditure as share of GDP is relatively low compared with peer countries.

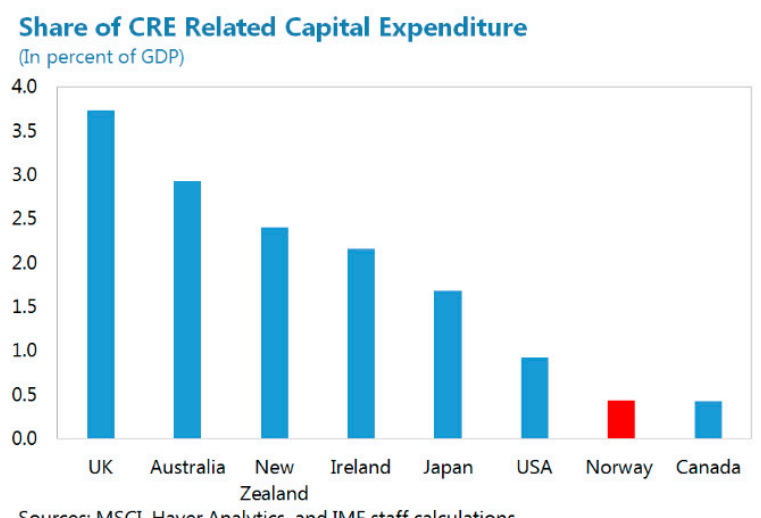
Sources: MSCI, Haver Analytics, and IMF staff calculations.

Corporates' financial positions have been improving, ...

Nonfinancial Corporation Financial Position

(Percent of mainland GDP)

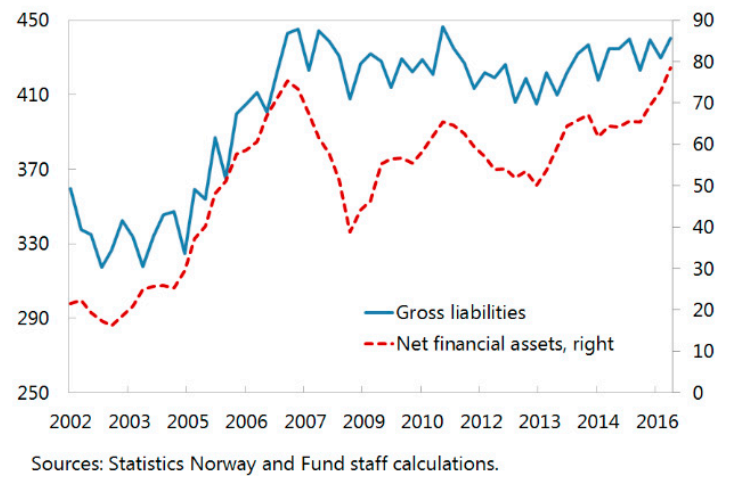

...so has their debt-service capacity, except for firms in oil service sector.

Debt Servicing Capacity for Listed Companies (Percent)

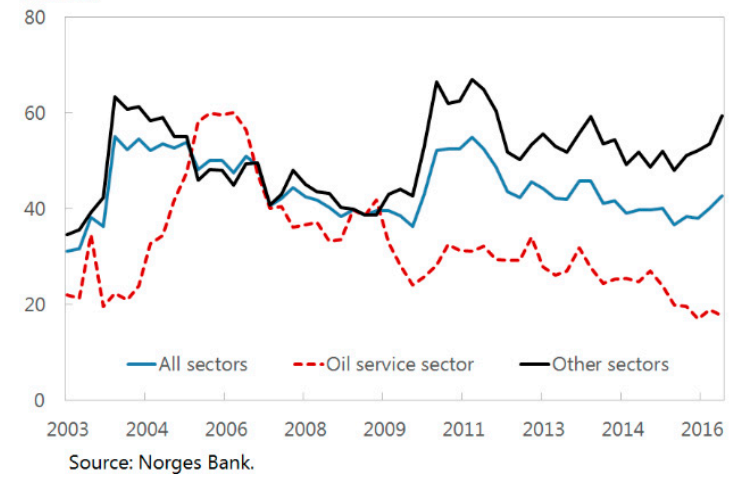


Figure 8. Norway: Banking Sector Developments

Higher countercyclical buffer and new leverage ratio requirements are being phased in.

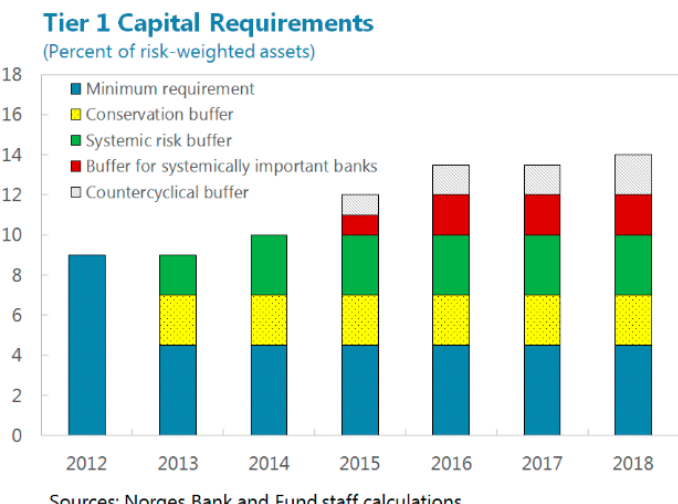

... including the additional Pillar II requirements, ...

CET1 Capital Ratios for the Largest 8 Banking Groups (Percent)

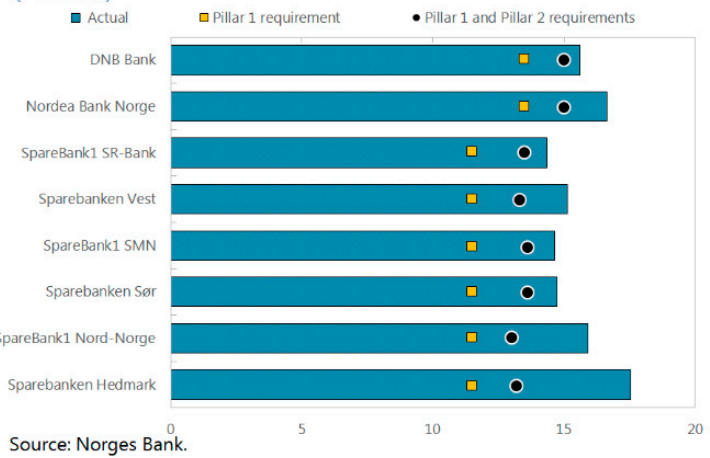

Banks' profitability declined slightly, partly due to rise in loan provisions, but remains high compared with peers.

Demestic Bank Return on Assets, 2016

(Percent of assets)

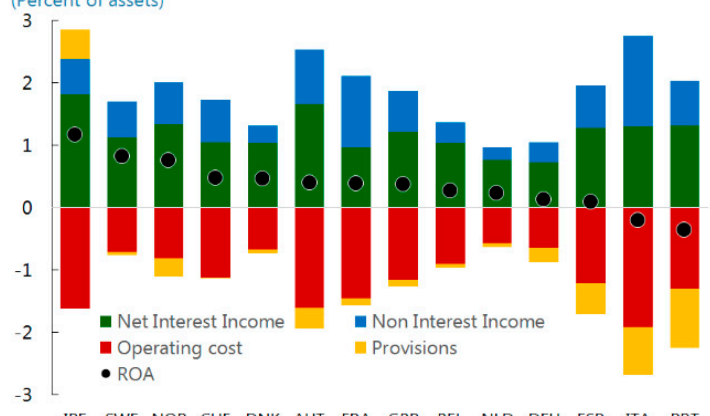

IRE SWE NOR CHF DNK AUT FRA GBR BEL NLD DEU ESP ITA PRT Sources: European Central Bank, SNL Financial, and IMF staff calculations.
With regulatory capital ratios strengthened over recent years, banks are well positioned to meet these new capital requirements, ...

Tier 1 Capital Ratios

(Percent)

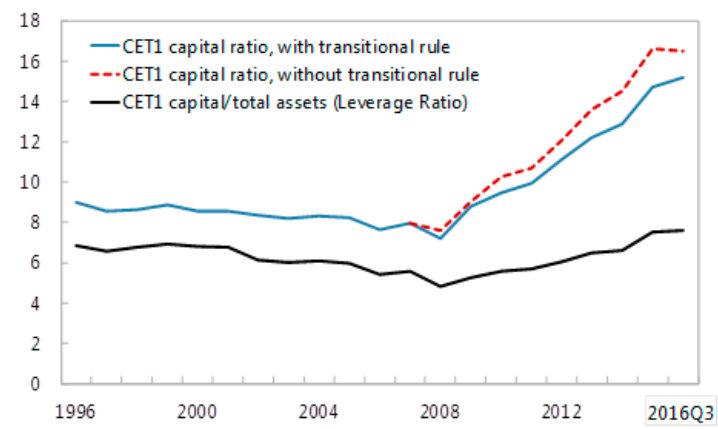

Sources: Norges Bank and Fund staff calculations.

... as well as new liquidity requirements, albeit with relatively low LCR in Norwegian krone.

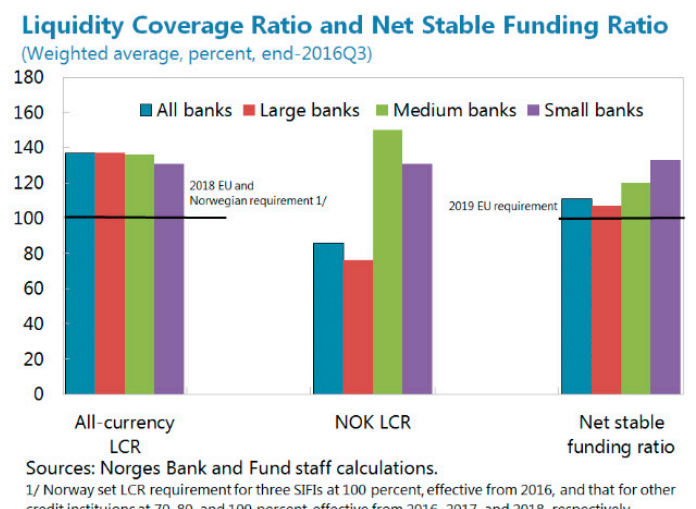

Nonperforming loans edged up over the past year, but stayed at a low level.

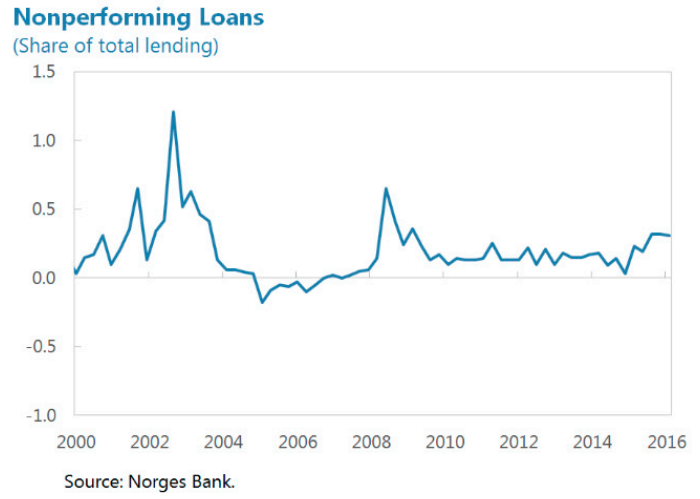


Table 2. Norway: Selected Economic and Social Indicators, 2012-2018

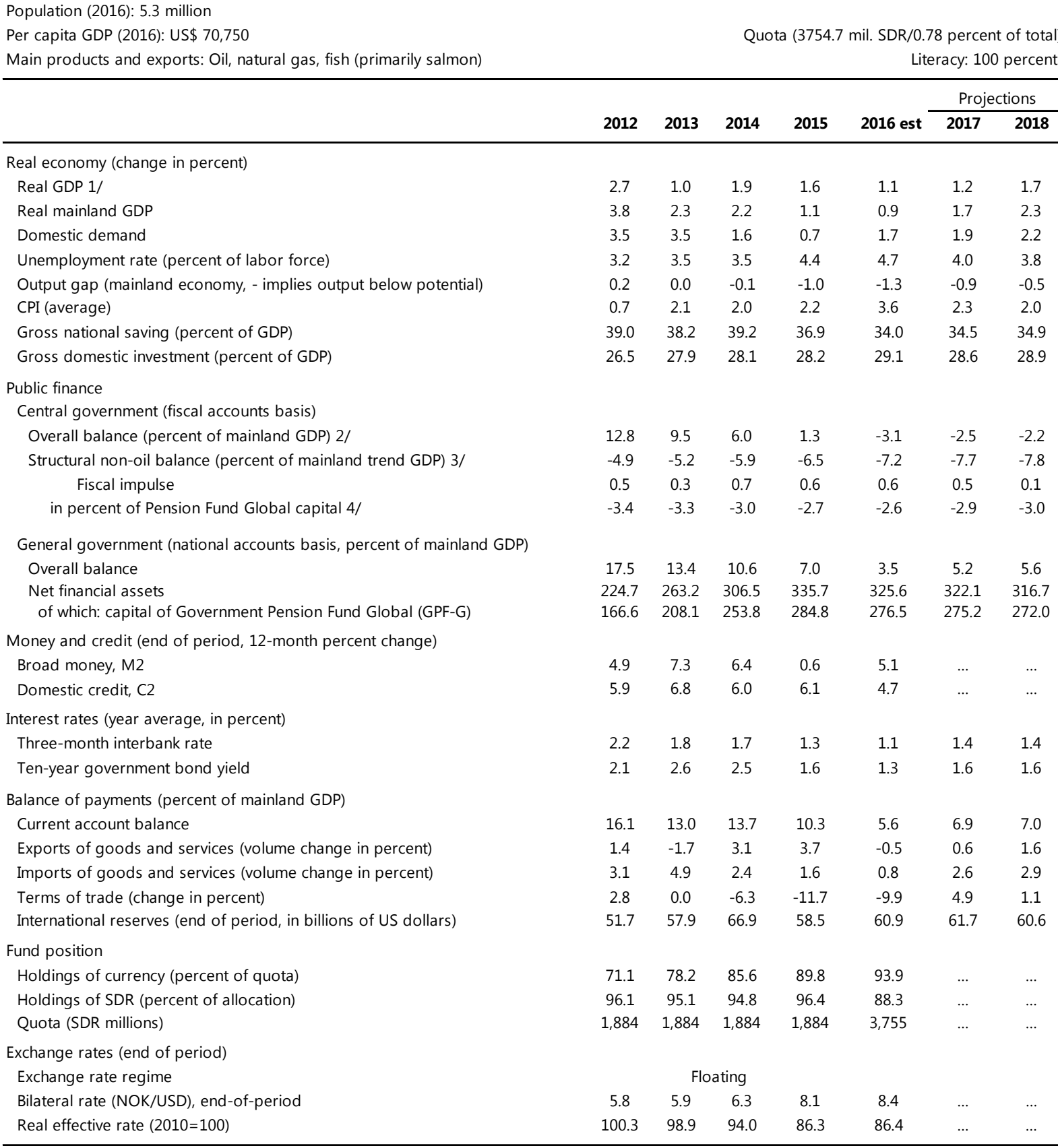

Sources: Ministry of Finance, Norges Bank, Statistics Norway, International Financial Statistics, United Nations

Development Programme, and Fund staff calculations.

1/ Based on market prices which include "taxes on products, including VAT, less subsidies on products".

2/ Projections based on authorities's 2017 revised budget

3/ Authorities' key fiscal policy variable; excludes oil-related revenue and expenditure, GPF-G income, as well as cyclical effects.

4/ Over-the-cycle deficit target: 4 percent, which is changed to 3 percent in 2017

\section{CInternational Monetary Fund. Not for Redistribution}


Table 3. Norway: Medium-Term Indicators, 2013-2022

(Annual percent change, unless otherwise noted)

\begin{tabular}{|c|c|c|c|c|c|c|c|c|c|c|}
\hline & \multirow[b]{2}{*}{2013} & \multirow[b]{2}{*}{2014} & \multirow[b]{2}{*}{2015} & \multirow[b]{2}{*}{2016} & \multicolumn{6}{|c|}{ Projections } \\
\hline & & & & & 2017 & 2018 & 2019 & 2020 & 2021 & 2022 \\
\hline Real GDP & 1.0 & 1.9 & 1.6 & 1.1 & 1.2 & 1.7 & 2.0 & 1.9 & 1.8 & 1.9 \\
\hline Real mainland GDP & 2.3 & 2.2 & 1.1 & 0.9 & 1.7 & 2.3 & 2.4 & 2.3 & 2.2 & 2.2 \\
\hline Real Domestic Demand & 3.5 & 1.6 & 0.7 & 1.7 & 1.9 & 2.2 & 2.1 & 1.8 & 1.6 & 1.6 \\
\hline Public consumption & 1.0 & 2.7 & 2.1 & 2.3 & 1.9 & 1.7 & 1.3 & 1.2 & 1.2 & 1.2 \\
\hline Private consumption & 2.7 & 1.9 & 2.1 & 1.6 & 2.0 & 2.2 & 2.4 & 2.2 & 2.1 & 2.1 \\
\hline Gross fixed investment & 6.3 & -0.7 & -3.8 & 0.3 & 2.2 & 3.0 & 3.0 & 1.9 & 1.6 & 1.6 \\
\hline Stockbuilding (contribution to growth) & 0.4 & 0.2 & 0.2 & 0.3 & 0.0 & 0.0 & 0.0 & 0.0 & 0.0 & 0.0 \\
\hline Trade balance of goods and services (contribution to growth) & -2.1 & 0.5 & 1.0 & -0.4 & -0.5 & -0.2 & 0.0 & 0.2 & 0.3 & 0.3 \\
\hline Exports of goods and services & -1.7 & 3.1 & 3.7 & -0.5 & 0.6 & 1.6 & 2.3 & 2.8 & 2.9 & 2.9 \\
\hline Mainland good exports & 1.3 & 3.1 & 5.8 & -8.2 & 2.3 & 3.9 & 4.0 & 4.1 & 4.3 & 4.3 \\
\hline Imports of goods and services & 4.9 & 2.4 & 1.6 & 0.8 & 2.6 & 2.9 & 2.9 & 2.7 & 2.6 & 2.6 \\
\hline Potential GDP & 1.2 & 2.0 & 2.6 & 1.4 & 0.8 & 1.3 & 1.5 & 1.8 & 1.8 & 1.9 \\
\hline Potential mainland GDP & 2.0 & 2.0 & 2.3 & 1.7 & 1.6 & 1.9 & 2.0 & 2.2 & 2.2 & 2.2 \\
\hline Output Gap (percent of potential) & 0.0 & -0.1 & -1.0 & -1.3 & -0.9 & -0.5 & -0.1 & 0.0 & 0.0 & 0.0 \\
\hline \multicolumn{11}{|l|}{ Labor Market } \\
\hline Employment & 0.7 & 1.1 & 0.5 & -0.1 & 0.8 & 1.0 & 1.1 & 1.1 & 1.1 & 1.1 \\
\hline Unemployment rate LFS (percent) & 3.5 & 3.5 & 4.4 & 4.7 & 4.0 & 3.8 & 3.7 & 3.7 & 3.7 & 3.7 \\
\hline \multicolumn{11}{|l|}{ Prices and Wages } \\
\hline GDP deflator & 2.5 & 0.3 & -2.3 & -1.2 & 5.4 & 2.6 & 2.7 & 2.5 & 2.5 & 2.5 \\
\hline Consumer prices (avg) & 2.1 & 2.0 & 2.2 & 3.6 & 2.3 & 2.0 & 2.2 & 2.3 & 2.5 & 2.5 \\
\hline Consumer prices (eop) & 2.0 & 2.1 & 2.3 & 3.5 & 2.6 & 2.1 & 2.3 & 2.5 & 2.5 & 2.5 \\
\hline \multicolumn{11}{|l|}{ Manufacturing sector } \\
\hline Hourly compensation & 5.3 & 3.2 & 2.3 & 1.5 & $\ldots$ & $\ldots$ & $\ldots$ & $\ldots$ & $\ldots$ & $\ldots$ \\
\hline Productivity & 1.4 & 0.5 & 4.9 & 0.5 & $\ldots$ & $\ldots$ & $\ldots$ & $\ldots$ & $\ldots$ & $\ldots$ \\
\hline Unit labor costs & 3.9 & 2.7 & -2.4 & 1.0 & $\ldots$ & $\ldots$ & $\ldots$ & $\ldots$ & $\ldots$ & $\ldots$ \\
\hline \multicolumn{11}{|l|}{ Fiscal Indicators } \\
\hline General government fiscal balance (percent of GDP) & 10.5 & 8.5 & 5.9 & 3.1 & 4.5 & 4.9 & 5.1 & 5.4 & 5.5 & 5.8 \\
\hline of which: nonoil balance (percent of mainland GDP) & -5.5 & -6.8 & -7.0 & -8.0 & -8.2 & -7.8 & -7.5 & -7.4 & -7.4 & -7.4 \\
\hline \multicolumn{11}{|l|}{ External Sector } \\
\hline Current account balance (percent GDP) & 10.2 & 11.0 & 8.7 & 4.9 & 5.9 & 6.0 & 6.2 & 6.3 & 6.3 & 6.4 \\
\hline Balance of goods and services (percent of GDP) & 10.7 & 8.9 & 5.4 & 1.2 & 2.6 & 2.7 & 2.8 & 2.8 & 2.8 & 2.9 \\
\hline Mainland balance of goods $1 /$ & -8.9 & -8.8 & -8.7 & -10.6 & -12.1 & -11.5 & -10.9 & -10.6 & -10.6 & -10.8 \\
\hline
\end{tabular}

Source: Statistics Norway, Ministry of Finance, and IMF staff estimates.

1/ Percent of mainland GDP. 
Table 4. Norway: External Indicators, 2013-2022

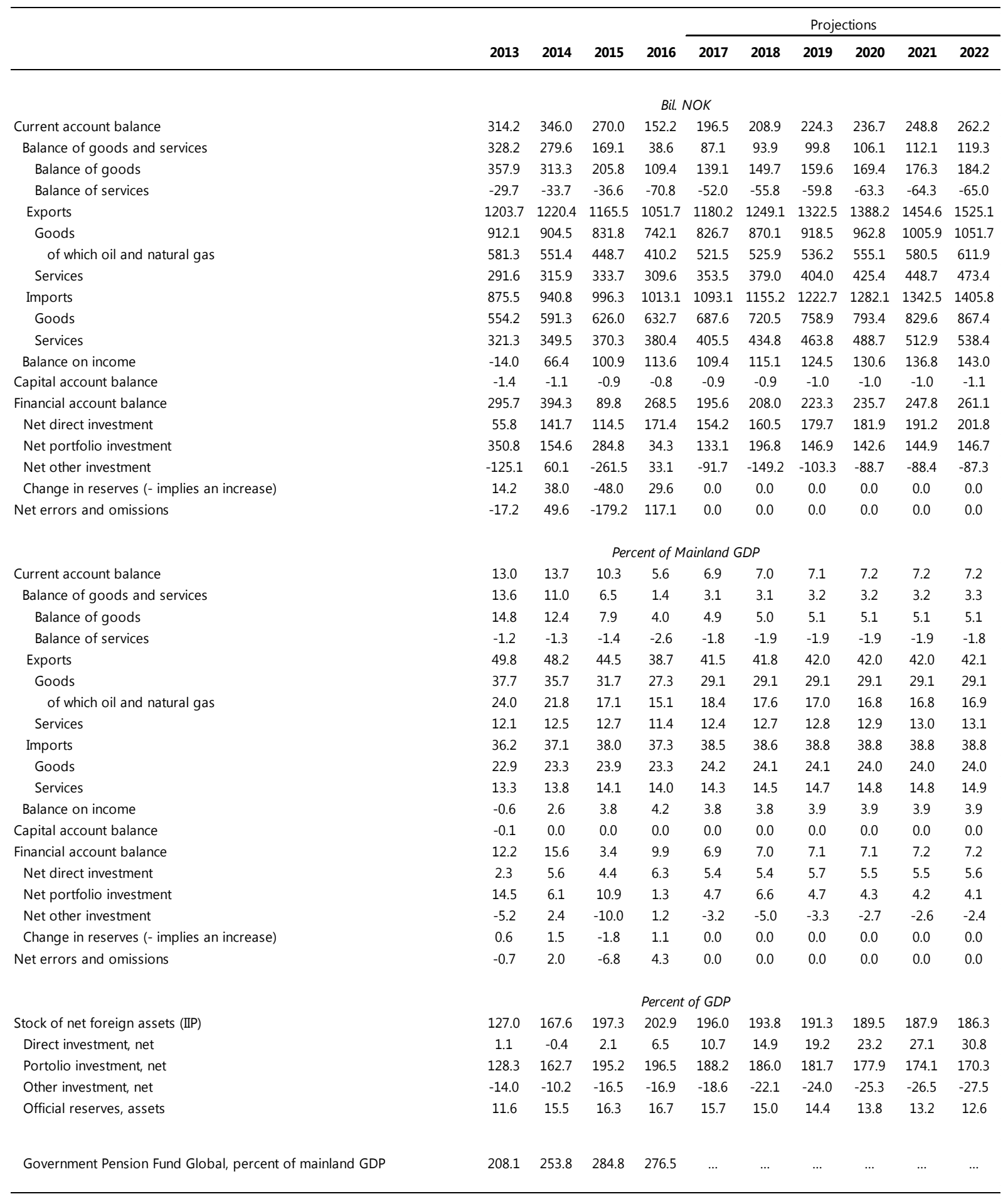

Sources: Statistics Norway; Ministry of Finance; and IMF staff calculations. 


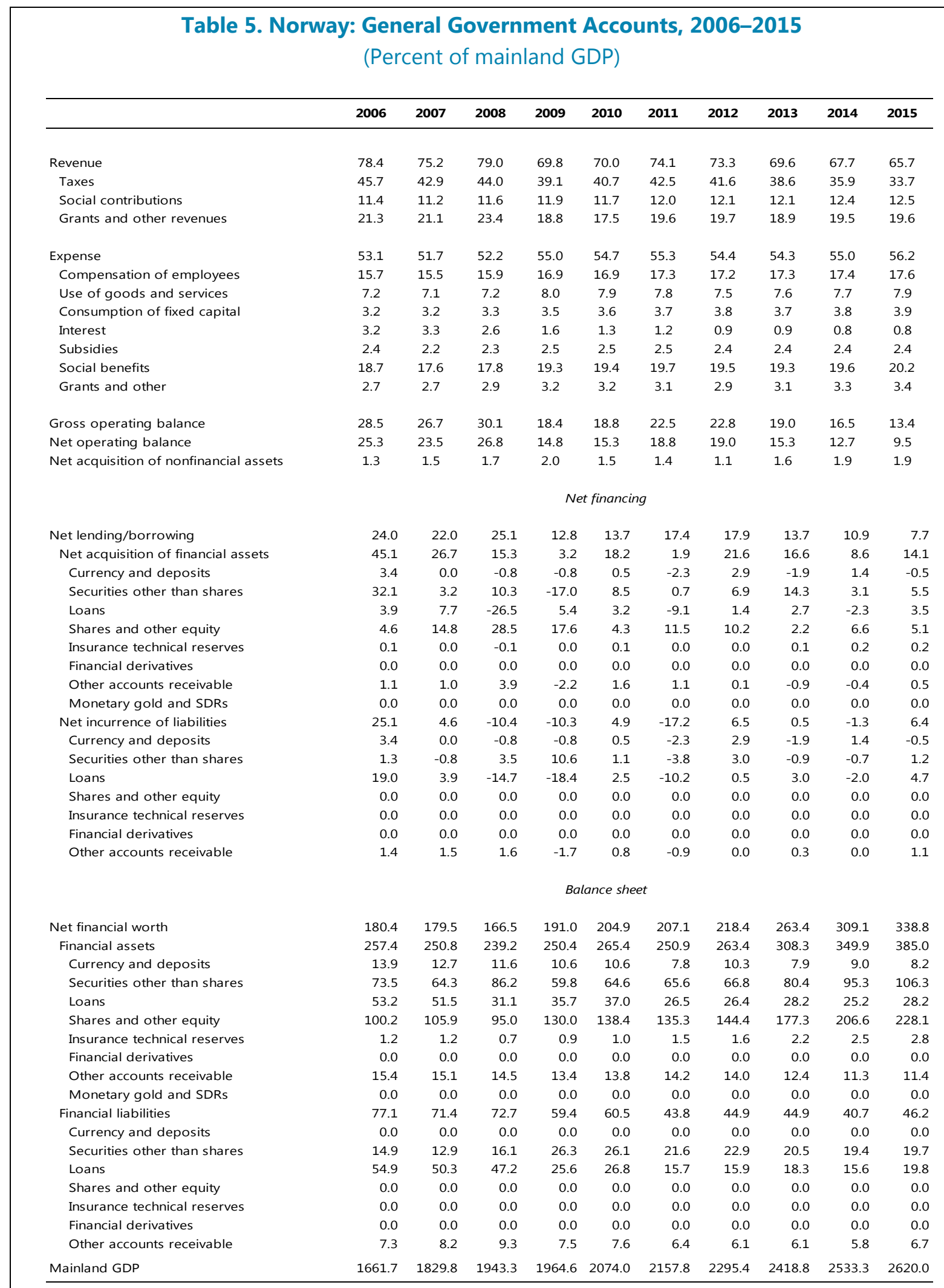

Sources: IMF Government Finance Statistics, Ministry of Finance, and Fund staff calculations. 


\section{Annex I. External Sector Assessment}

Norway's net international investment position remains strong. However, the current account surplus has substantially decreased and the deficit in the non-oil trade is now almost as high as the surplus from oil-related exports. This is due to weaker oil prices, but also to the rebalancing toward non-oil tradable exports remaining relatively slow. Cost competitiveness remains an issue, although wage restraint is bearing some fruit. There is a risk that a sustained reversal of the krone toward appreciation could hamper productivity-enhancing investments, including in the manufacturing sector. Based on the EBA methodology, Staff assess Norway's external position to be moderately weaker than implied by medium term fundamentals.

47. Norway's net international investment and reserve positions remain strong. In 2016, the net international investment position (NIIP) was broadly steady at 233 percent of mainland GDP. The general government is the main external creditor with net external assets of 262 percent of mainland GDP, driven by the Government Pension Fund Global (assets of 274 percent of mainland GDP). Banks remain the largest net external debtors given reliance on wholesale funding; their net external liabilities stand at 53 percent of mainland GDP. International reserves have remained stable over the last years at a comfortable 19 percent of mainland GDP. Norway has a free-floating exchange rate regime and has not intervened in the foreign exchange market since January 199919

\section{The decline in the current account surplus has been driven by low oil prices, but also} by cost competitiveness challenges of non-oil exporters. Norway's current account surplus stood at 5.6 percent of mainland GDP in 2016, a decline of $43 / 4$ percentage points compared to 2015 . It is over 10 percentage points lower than its post-crisis peak in 2012. The decline has mainly been driven by lower oil prices and with their stabilization, a moderate recovery is already underway. Non-oil exports will benefit from positive base effects in 2017 because of temporary shutdowns of several large industrial enterprises in

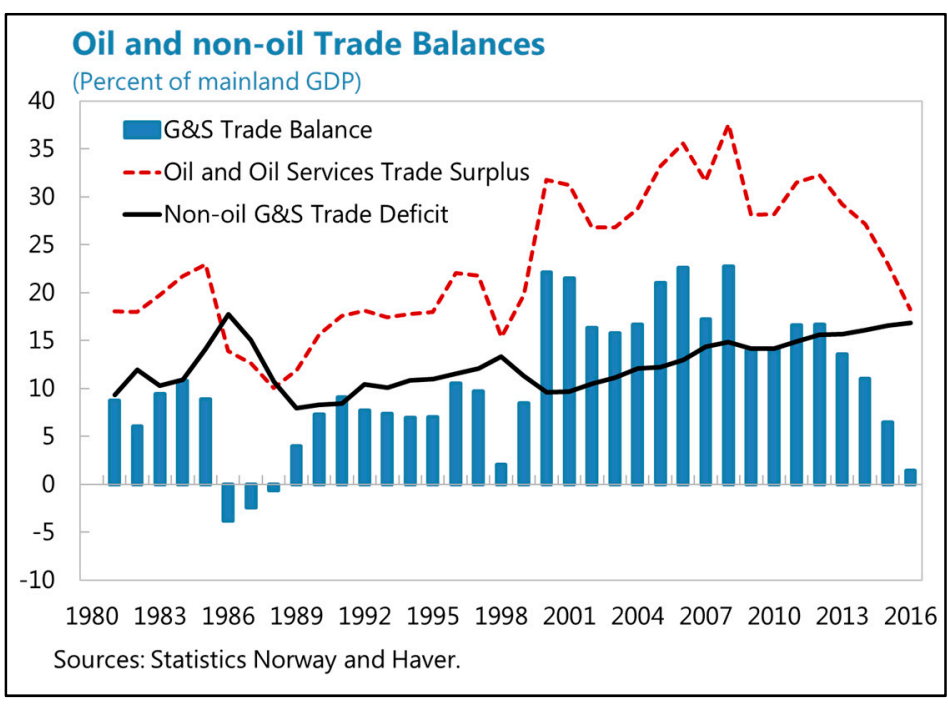
the second half of 2016 due to production upgrades or outages. Thus, the current account surplus is expected to return to around7 percent of mainland GDP over the medium term. However, the

\footnotetext{
${ }^{19}$ Foreign exchange purchases or sales for the GPFG are publicly preannounced on the Norges Bank website. In extraordinary circumstances, the Norges Bank may provide foreign exchange liquidity via collateralized operations. This was done between September 2008 and July 2009. The Norges Bank could in theory intervene in the FX market if the krone deviated substantially from a level deemed reasonable in relation to fundamentals or if exchange rate developments weaken prospects of achieving the inflation target.
} 
upside potential for the current account is limited by continued cost competitiveness challenges in the non-oil sector. During 2016, non-oil export value fell by 1.3 percent of mainland GDP, outstripping an import value decline of 0.8 percent of mainland GDP. The non-oil trade deficit now surpasses $161 / 2$ percent of mainland GDP, approaching the magnitude of the oil-related surplus. As a result, the current account balance at present is mainly driven by the primary income surpluses generated by the GPFG.

\section{Financial account vulnerability is low; the banking sector's reliance on external} wholesale funding could be a source of vulnerabilities. In 2016, FDI and portfolio flows constituted about $2 / 3$ and $1 / 3$ of the capital and financial account balance. Flows, both outgoing and incoming, are mainly to other Nordic and EU countries. With bank's heavy reliance on wholesale funding - accounting for about half of total banks' funding - and 60 percent of wholesale funding from foreign sources, banks are vulnerable to turbulence in foreign financial markets.

\section{Norway's real effective exchange rate (REER) appreciated moderately in 2016.}

Norway's exchange rate is highly correlated with oil prices, the main driver of the terms of trade. Following the substantial depreciation during 2013-15, the krone started to appreciate in January 2016 along with the oil price recovery. Since the last assessment based on April 2016 data, the REER is about 4 and 2 percent stronger on CPI and ULC bases, respectively (as of April 2017). The CPIbased REER has been relatively flat during the last two decades and stands currently $71 / 2$ percent below its long-term average.

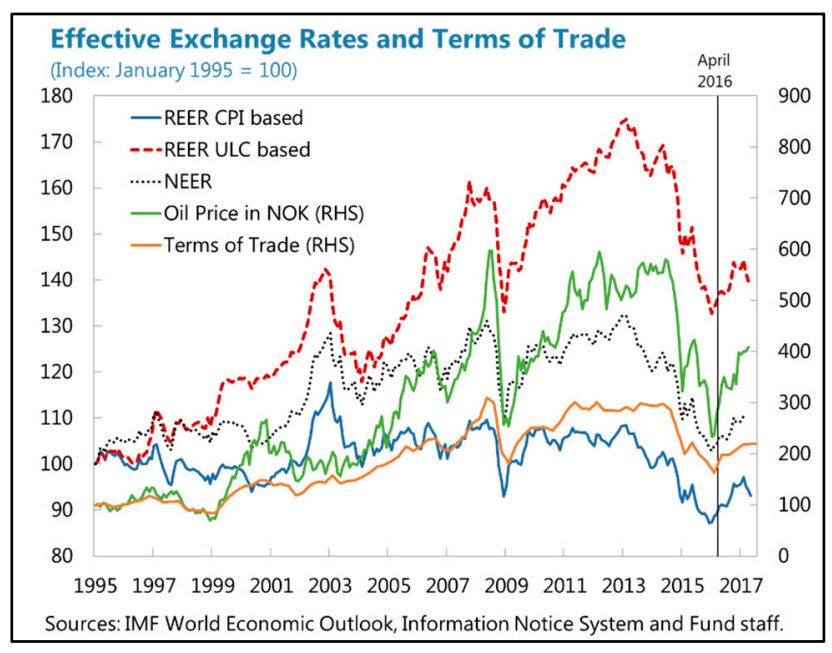

\begin{tabular}{|c|c|c|c|c|}
\hline & \multicolumn{3}{|c|}{ Changes } & \multirow{2}{*}{$\begin{array}{c}\text { Levels 1/ } \\
\text { (relative to } \\
\text { 1995-2016 avg.) }\end{array}$} \\
\hline & $\begin{array}{l}\text { Feb } 2013 \text { peak to } \\
\text { Jan } 2016 \text { trough 2/ }\end{array}$ & $\begin{array}{c}\text { Since Jan } 2016 \\
\text { trough }\end{array}$ & $\begin{array}{c}\text { Since April } 2016 \\
\text { (Last assessment) }\end{array}$ & \\
\hline REER CPI-based & -19.6 & 7.8 & 3.8 & -7.5 \\
\hline REER ULC-based & -23.1 & 5.3 & 1.8 & 2.8 \\
\hline NEER & -21.9 & 3.6 & 0.6 & -8.3 \\
\hline Terms of Trade & -46.9 & 75.0 & 38.0 & 36.1 \\
\hline Oil Price in NOK & -39.2 & 28.8 & 17.5 & 15.2 \\
\hline
\end{tabular}

51. Despite some progress, the economic rebalancing toward non-oil tradables has remained rather slow. The downturn in oil export value serves to clearly expose the continuing cost 
competitive problems. High wages and low productivity increases from the mid-2000s-by pushing Norway's unit labor cost trajectory considerably above that of trade partners-are still making themselves felt and were particularly pronounced in non-oil export sectors. At present, the ULC-based REER remains 45 percent higher than during the mid-1990s, despite the substantial krone depreciation of 2013-15. That said, wage restraint is bearing some fruit with wage shares in non-oil export sectors declining in recent years, but closing the gap will likely also require higher productivity (Figure 9).

\section{Figure 9. Norway: Developments in Non-Oil Competitiveness}

The 2013-15 krone depreciation has not yet resulted in a marked increase in non-oil export market share.

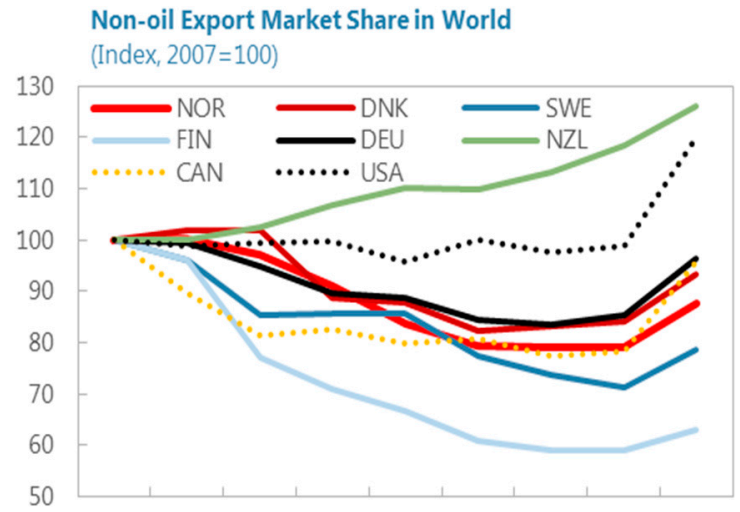

200720082009201020112012201320142015

Sources: UN Comtrade and Fund Staff calculations.

The manufacturing export sector is smaller today than in 1990, when oil constituted the same share of GDP.

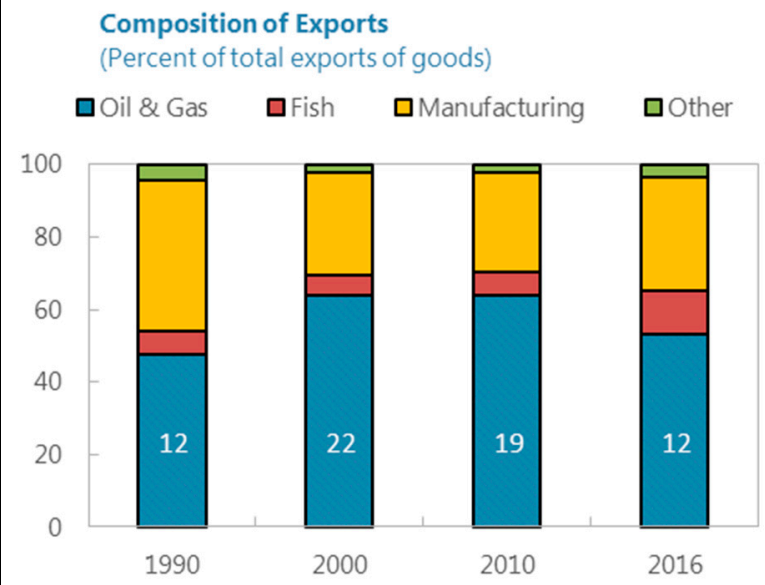

Sources: Statistics Norway and Nordic Petroleum Directorate. Note: Overlay figure is share of oil and gas in GDP (Percent).
Especially, manufacturing exports have not experienced a strong recovery and have recently come under pressure.

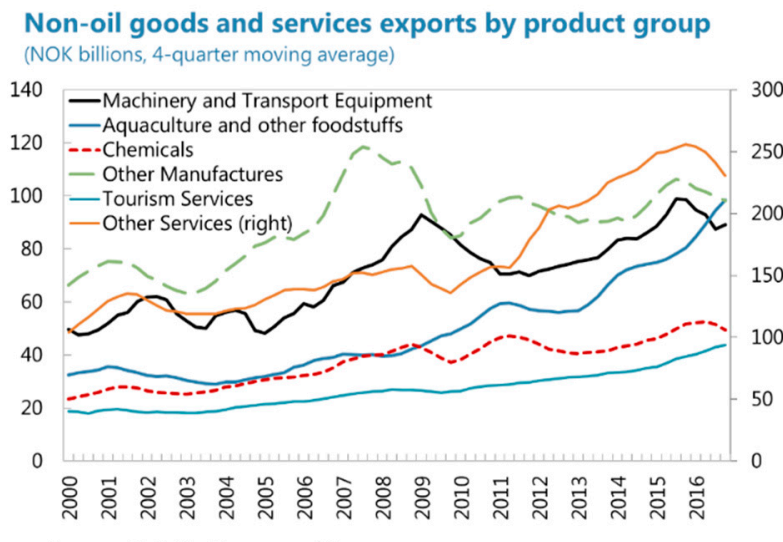

Sources: Statistics Norway and Haver.

Wage restraint is helping to reestablish competitiveness, but stronger productivity increases will also be needed.

Wage Shares

(Percent of value added)

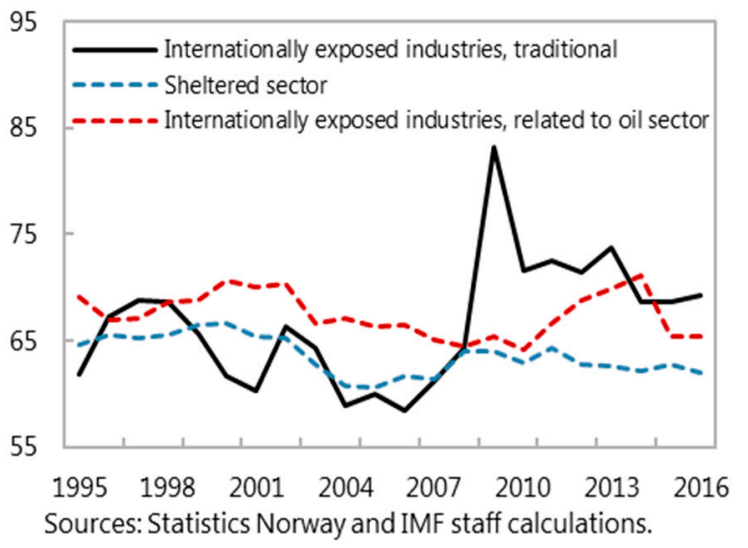

52. There has been considerable divergence among industries, with especially manufacturing continuing to struggle. Manufacturing exports have not experienced a dynamic expansion in response to the 2013-15 depreciation, hinting at manufacturing capacity having been 
eroded during the last decade, although some drag has also been exerted trough lower global demand for oil equipment manufactures. Moreover, their recovery seems to have been cut short with the krone's shift toward appreciation in 2016. The manufacturing export sector today is smaller today than in 1990, when oil represented the same share of GDP (of 12 percent). Alongside wage restraint, a return to krone depreciation, as observed this spring, would be welcome to incentivize needed investments to rebuild capacity. Meanwhile, tradable sectors that did perform well during the last several years are those profiting from inherent competitive advantages, such the engineering industry providing oil-related services and aquaculture (which also profited from strong increases in global salmon prices). Tourism has also profited from the 2013-15 depreciation, as capacity issues likely pose less of a constraint than in manufacturing.

\section{Staff consider Norway's external position to be moderately weaker than implied by} medium- term fundamentals and desirable policies. The assessment is confirmed by the modelbased estimates. As in the past, staff analysis focuses on the CA and REER index estimates. Although they are also surrounded by uncertainty, these estimates are the most reliable for Norway and their simple average points to a moderate krone overvaluation. ${ }^{1}$ The CA analysis model points to a stronger overvaluation, because it estimates the norm for Norway's current account, as implied by fundamentals, to be 4.4 percent higher than the observed 2016 current account. Staff judges that the actual difference more likely lies within the range of 1 to 2 percent of GDP, since the CA model does not fully capture the cyclical effects of lower terms of trade on the current account.

Considering that oil exports and exports from the oil services industry still represented more than 17 percent of GDP in 2016, a temporary decline in oil prices has a stronger cyclical effect than the one estimated in the model. This implies a larger cyclically adjusted current account and a smaller current account gap.

\begin{tabular}{|lcc|}
\hline External Balance Assessment (EBA) & Methodologies 1/ \\
\hline Methodology & $\begin{array}{c}\text { CA gap } \\
\text { (Percent of GDP) }\end{array}$ & $\begin{array}{c}\text { REER gap } \\
\text { (Percent) }\end{array}$ \\
\hline EBA CA Analysis & -4.4 & 12.9 \\
EBA REER (Index) Analysis & -- & -6.5 \\
EBA REER (Level) Analysis & -- & -25.7 \\
EBA External Sustainability Approach & -2.1 & 6.2 \\
\hline Source: Fund staff calculations. & \multicolumn{2}{|l}{} \\
1/ CA gaps: minus indicates overvaluation. REER gaps: minus \\
indicates undervaluation. Estimates based on data available in April \\
2017.
\end{tabular}

\footnotetext{
${ }^{20}$ IMF Country Report 16/214 provides explanations why the REER level and ES approaches (with their large and opposing estimates) do not seem very suitable for Norway.
} 


\section{Annex II. Authorities' Response to Past IMF Recommendations}

\begin{tabular}{|c|c|}
\hline Fund Policy Advice from 2016 Consultation & Authorities' Actions \\
\hline $\begin{array}{l}\text { Fiscal Policy: } \\
\text { Directors broadly agreed with the expansionary } \\
\text { stance in } 2016 \text { and stressed the need for well- } \\
\text { targeted temporary measures that also } \\
\text { promote rebalancing the economy toward } \\
\text { non-oil tradable sectors. } \\
\text { Directors recommended a gradual shift to a } \\
\text { more neutral fiscal stance as the economy } \\
\text { returns to potential. }\end{array}$ & $\begin{array}{l}\text { The } 2017 \text { revised budget consists of measures } \\
\text { that are pro-transition, including special } \\
\text { measures to combat unemployment in the } \\
\text { regions and industries mostly affected by the } \\
\text { oil downturn, increasing investments in } \\
\text { infrastructure, research and innovation and } \\
\text { continued implementation of tax reform } \\
\text { entailing corporate and personal income tax } \\
\text { cuts. }\end{array}$ \\
\hline $\begin{array}{l}\text { Directors supported recent reforms to shift } \\
\text { from personal and corporate income taxation } \\
\text { to promote productive investment. } \\
\text { Directors welcomed the ongoing review of the } \\
\text { fiscal rule, aimed at ensuring continued } \\
\text { prudent management of the country's oil } \\
\text { wealth, taking into account the interests of } \\
\text { future generations. }\end{array}$ & $\begin{array}{l}\text { The } 2017 \text { revised budget entails a smaller fiscal } \\
\text { stimulus than last year. } \\
\text { The government announced an increase of the } \\
\text { equity allocation of the GPFG from } 62.5 \text { to } \\
70 \text { percent, and a downward revision of the } \\
\text { projected real return on the GPFG from } 4 \text { to } \\
3 \text { percent. The white paper was submitted to } \\
\text { the Parliament in April } 2017 \text {. }\end{array}$ \\
\hline $\begin{array}{l}\text { Macroprudential Policy: } \\
\text { Directors recommended that the authorities } \\
\text { continue monitoring the development of } \\
\text { household debt and house prices, and } \\
\text { promptly tighten macroprudential measures to } \\
\text { address emerging financial stability risks. }\end{array}$ & $\begin{array}{l}\text { The countercyclical capital buffer will be } \\
\text { increased to } 2 \text { percent from December } 31 \text {, } \\
2017 . \\
\text { The Ministry of Finance adopted a new } \\
\text { regulation, which will take effect from } 1 \\
\text { January } 2017 \text { to } 30 \text { June } 2018 \text {. The new } \\
\text { regulation, among other measures, introduced } \\
\text { a DTI limit to complement affordability test, } \\
\text { tightened the condition for applying } \\
\text { amortization requirement, and lowered the LTV } \\
\text { limit for purchasing a second home to } \\
60 \text { percent and the speed limit (the percentage } \\
\text { of new mortgages that can deviate from } \\
\text { mortgage requirement) to } 8 \text { percent for Oslo. } \\
\text { Banks will also be subject to a } 5 \text { percent } \\
\text { leverage ratio requirement with an exception } \\
\text { for DNB ( } 6 \text { percent) from } 30 \text { June } 2017 \text {. }\end{array}$ \\
\hline
\end{tabular}




\begin{tabular}{|c|c|}
\hline $\begin{array}{l}\text { tructural Reforms: } \\
\text { Directors saw merit in continued restraint in } \\
\text { wage settlements and further reforms to } \\
\text { einvigorate productivity growth and increase } \\
\text { abor force participation through better } \\
\text { lignment of public sector pensions with recent } \\
\text { rivate sector pension reforms and reforms to } \\
\text { ickness and disability pensions. } \\
\text { Directors also saw scope for efficiency gains } \\
\text { rom reducing tax preferences for owner- } \\
\text { eccupied housing and relaxing supply } \\
\text { estrictions in the housing } \\
\text { narket. }\end{array}$ & $\begin{array}{l}\text { The social partners demonstrated needed wage } \\
\text { flexibility in the recent years' wage settlements } \\
\text { as nominal wage growth remains modest } \\
\text { ( } 2.4 \text { percent in 2017, } 1.7 \text { percent in } 2016 \text { and } \\
2.8 \text { percent in 2015). } \\
\text { Effective in January 2017, (i) a new mandatory } \\
\text { activity requirement was introduced for social } \\
\text { assistance recipients under } 30 \text { years of age and } \\
\text { (ii) stricter eligibility criteria and activity checks } \\
\text { were introduced for sickness leave benefits. } \\
\text { Reforms to the 'youth guarantee' program are } \\
\text { being rolled out to guarantee unemployed } \\
\text { youth access to ALMPs within } 8 \text { weeks and } \\
\text { should be in place nationwide by end } \\
2017 . \text { Reforms to the work assessment } \\
\text { allowance (an extended incapacity benefit) are } \\
\text { currently being considered by parliament and } \\
\text { include a shortening of its duration. Finally, } \\
\text { child care provision has been considerably } \\
\text { expanded during the last years and reforms to } \\
\text { vocational and higher education are ongoing. } \\
\text { The taxable value of secondary dwellings for } \\
\text { net wealth taxation has been increased from } \\
80 \text { to } 90 \text { percent of estimated market value } \\
\text { since January } 2017 \text {. } \\
\text { A new tax deduction scheme for investments in } \\
\text { startups has been proposed in the } 2017 \text { revised } \\
\text { budget. }\end{array}$ \\
\hline
\end{tabular}




\section{Annex III. Status of FSAP Recommendations}

\begin{tabular}{|c|c|c|}
\hline Priority Recommendations & Time & Status \\
\hline \multicolumn{3}{|c|}{ Macroprudential Policies and Framework } \\
\hline $\begin{array}{l}\text { Consider additional measures to contain systemic } \\
\text { risks arising from the growth of house prices and } \\
\text { household indebtedness (e.g., stricter loan-to- } \\
\text { value (LTV) ratios, and loan-to-income or debt } \\
\text { service ratio to supplement the affordability test) }\end{array}$ & $\mathrm{S}$ & $\begin{array}{l}\text { Mostly done. In June 2015, the Ministry of } \\
\text { Finance adopted a regulation on requirements } \\
\text { for residential mortgage loans, which } \\
\text { converted FSA guidelines into explicit } \\
\text { requirements, effective from } 1 \text { July } 2015 \text { to } \\
\text { end-2016. In replace of this regulation, in } \\
\text { December } 2016 \text { the Ministry of Finance } \\
\text { adopted a new mortgage regulation-which } \\
\text { takes effect from } 1 \text { Jan } 2017 \text { to } 30 \text { June } 2018 \text {. } \\
\text { The new regulation, among other changes, } \\
\text { introduces a debt-to-income limit, tightens the } \\
\text { down payment requirements, and lowers the } \\
\text { speed limit (the percentage of new mortgages } \\
\text { that can deviate from mortgage requirements) } \\
\text { for Oslo. The requirements will be continuously } \\
\text { assessed in light of developments in the } \\
\text { housing market, household borrowing, and } \\
\text { competition between lenders. }\end{array}$ \\
\hline $\begin{array}{l}\text { Consider measures to contain risks related to } \\
\text { banks' wholesale funding (e.g. limits could be } \\
\text { placed on the mismatch between the maturity of } \\
\text { currency swaps (and other hedging techniques) } \\
\text { and the maturity of the underlying exposures) }\end{array}$ & $\mathrm{S}$ & $\begin{array}{l}\text { Partly done. On } 25 \text { November } 2015 \text {, the } \\
\text { Ministry of Finance adopted new liquidity rules } \\
\text { which set the total "all currency" LCR } \\
\text { requirement at } 100 \text { percent for the three SIFIs } \\
\text { and at } 70 \text { percent for other credit institutions, } \\
\text { effective from end-2015. The requirement for } \\
\text { other credit institutions will be increased from } \\
70 \text { percent to } 80 \text { percent from end-2016, and } \\
\text { to } 100 \text { percent by end-2017. As requested by } \\
\text { the Ministry, in September } 2016 \text { the FSA } \\
\text { submitted its assessment on LCR requirements } \\
\text { for individual (significant) currencies, proposing } \\
\text { the introduction of LCR in significant currencies } \\
\text { equal to the level applying to all currencies } \\
\text { combined, with the exception of Norwegian } \\
\text { krone in the case of institutions having the } \\
\text { euro and/or US dollar as a significant currency. } \\
\text { For such institutions, LCR requirement in the } \\
\text { krone is proposed at } 50 \text { percent. In addition, a } \\
\text { NSFR requirement is expected to be introduced } \\
\text { after final EU rules are adopted. }\end{array}$ \\
\hline $\begin{array}{l}\text { Improve the existing institutional structure for } \\
\text { macroprudential policies. This should include }\end{array}$ & M & Under consideration. \\
\hline
\end{tabular}


more standardized and transparent procedures for giving advice to the MOF; a transparent "comply or explain" approach by decisionmakers; and, in due course, greater delegation of decision-making powers over macroprudential instruments to NB or the FSA.

\section{Stress Tests}

Improve liquidity monitoring by performing liquidity stress tests using the structure of cash flows at various maturities; or applying customized versions of the LCR along the maturity ladder. Consider options to discourage cross-ownership of covered bonds.
$\mathrm{M}$

Partly done. The FSA and Norges Bank have set up a joint working group on liquidity stress testing. The set up uses cash flow structures at different maturities and funding gaps are calculated under three different stress scenarios. The work is currently in its final stages. Since September 2016 credit institutions have reported additional Monitoring Metrics (CRD IV).

M $\quad$ Ongoing. The Solvency II legislation entered into force on 1 January 2016. Norwegian undertakings participated in the European Insurance and Occupational Pensions Authority (EIOPA) stress-test in 2016. The FSA conducted three thematic on-site inspections in the largest life insurance undertakings during the autumn of 2016, and another three inspections in medium sized undertakings are carried out during March to May this year. The main focus of the inspections is calculation and validation of the technical provisions and the solvency capital requirement. The inspections cover governance, documentation and validation on a general basis, as well as more detailed issues regarding methods, assumptions and data used.

S

Ongoing. In a letter January 2017 to all life insurance undertakings FSA stated that life insurance undertakings should not pay dividends as long as surplus on the insurance policies are used to strengthen reserves

Achieve recapitalization of weakly capitalized insurance companies in the current environment. Continue to restrict dividend payouts by the companies with weak capital adequacy. according to new requirements (new mortality tables). The letter stated further that where life insurance undertakings have been allowed to use the transitional rule for technical provisions, FSA assumes that the board of insurance undertakings make proper reviews of the need for capital accumulation in the undertaking both in the short and long term. 


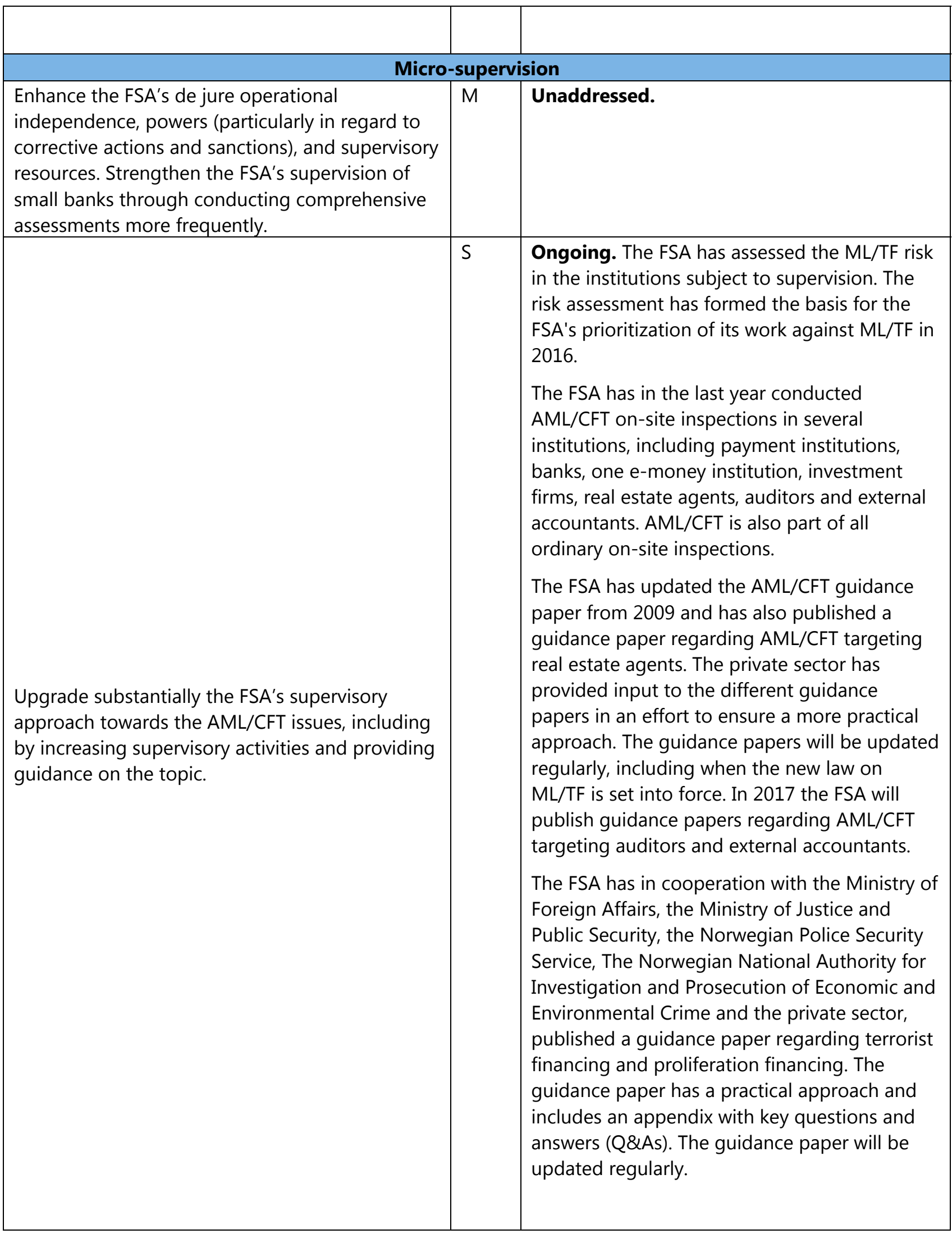




\begin{tabular}{|c|c|c|}
\hline & & $\begin{array}{l}\text { The authorities also aim to publish the national } \\
\text { risk assessment by mid-2017, and are drafting } \\
\text { proposals to strengthen the AML/CFT legal } \\
\text { framework. }\end{array}$ \\
\hline \multicolumn{3}{|c|}{ Financial Market Infrastructure } \\
\hline $\begin{array}{l}\text { Strengthen operational risk management related } \\
\text { to outsourcing in systemically important payment } \\
\text { systems. }\end{array}$ & $\mathrm{S}$ & $\begin{array}{l}\text { Partly done. The risk management framework } \\
\text { for the NICS (clearing) system has been } \\
\text { improved, and is now fully compliant with the } \\
\text { CPMI/IOSCO principles for financial market } \\
\text { infrastructures. Organizational changes and } \\
\text { plans for some increased resources for the } \\
\text { NICS system ownership function will be } \\
\text { implemented, on the condition that Norges } \\
\text { Bank approves the changes. A new operational } \\
\text { set-up for the NICS system is under } \\
\text { preparation. An enhanced contingency solution } \\
\text { for the NBO (RTGS) system was implemented } \\
\text { in November 2015. }\end{array}$ \\
\hline \multicolumn{3}{|c|}{ Safety Nets } \\
\hline $\begin{array}{l}\text { The MOF should initiate resolution planning for } \\
\text { the largest banks, including assessing } \\
\text { impediments to resolvability, and delegate } \\
\text { specific responsibilities to the FSA, and define } \\
\text { expectations for the Norway-specific elements of } \\
\text { the recovery and resolution plans of foreign bank } \\
\text { subsidiaries and branches. }\end{array}$ & $\mathrm{S}, \mathrm{M}$ & $\begin{array}{l}\text { Ongoing. An official committee, the Banking } \\
\text { Law Commission, presented on } 26 \text { October } \\
2016 \text { draft statutory provisions to transpose } \\
\text { the BRRD into Norwegian law. This document } \\
\text { also contains a proposal for implementing the } \\
\text { EU's updated Deposit Guarantee Directive from } \\
\text { 2014. An implementation of the BRRD will } \\
\text { encompass a framework for resolution } \\
\text { planning and issues regarding branches and } \\
\text { subsidiaries of foreign banks. }\end{array}$ \\
\hline $\begin{array}{l}\text { Enhance the legal framework for resolution to } \\
\text { comply with the FSB Key Attributes, in particular } \\
\text { with regard to the resolution toolkit, operational } \\
\text { independence, legal protection for the resolution } \\
\text { authorities and administration boards, } \\
\text { establishing earlier triggers for resolution, cross- } \\
\text { border resolutions, and the distinction between } \\
\text { going concern and gone concern resolution. }\end{array}$ & $\mathrm{S}$ & $\begin{array}{l}\text { Ongoing. If all elements of the BRRD are } \\
\text { properly transplanted into Norwegian law, the } \\
\text { national law will ensure implementation of the } \\
\text { FSB Key Attributes. }\end{array}$ \\
\hline $\begin{array}{l}\text { The BGF should adopt policies specifying under } \\
\text { what conditions board members must recuse } \\
\text { themselves, considering actual and prospective } \\
\text { conflicts of interest. }\end{array}$ & $S$ & $\begin{array}{l}\text { Done. The BGF has adopted new policies } \\
\text { specifying the following circumstances under } \\
\text { which board members must recuse themselves: } \\
\text { 1) When there is a possibility that a company } \\
\text { the board member has an interest in would bid } \\
\text { on a problem bank or part of its assets; } \\
\text { 2) When there is a possibility that the whole } \\
\text { bank in which the board member has an } \\
\text { interest, or parts of its assets or its deposit } \\
\text { portfolio may be sold. }\end{array}$ \\
\hline
\end{tabular}




\begin{tabular}{|l|l|l|}
\hline & $\begin{array}{l}\text { The board members must consider whether to } \\
\text { recuse themselves based on these criteria } \\
\text { before a meeting where support from the BGF } \\
\text { will be discussed. When the problem situation } \\
\text { is over, the board shall review how the recusal } \\
\text { was handled. The policies are available on the } \\
\text { BGF's website. } \\
\text { (http://www.bankenessikringsfond.no/no/Hove } \\
\text { d/Om-oss/Styre/ in Norwegian only.) }\end{array}$ \\
\hline
\end{tabular}




\section{Annex IV. Debt Sustainability Analysis}

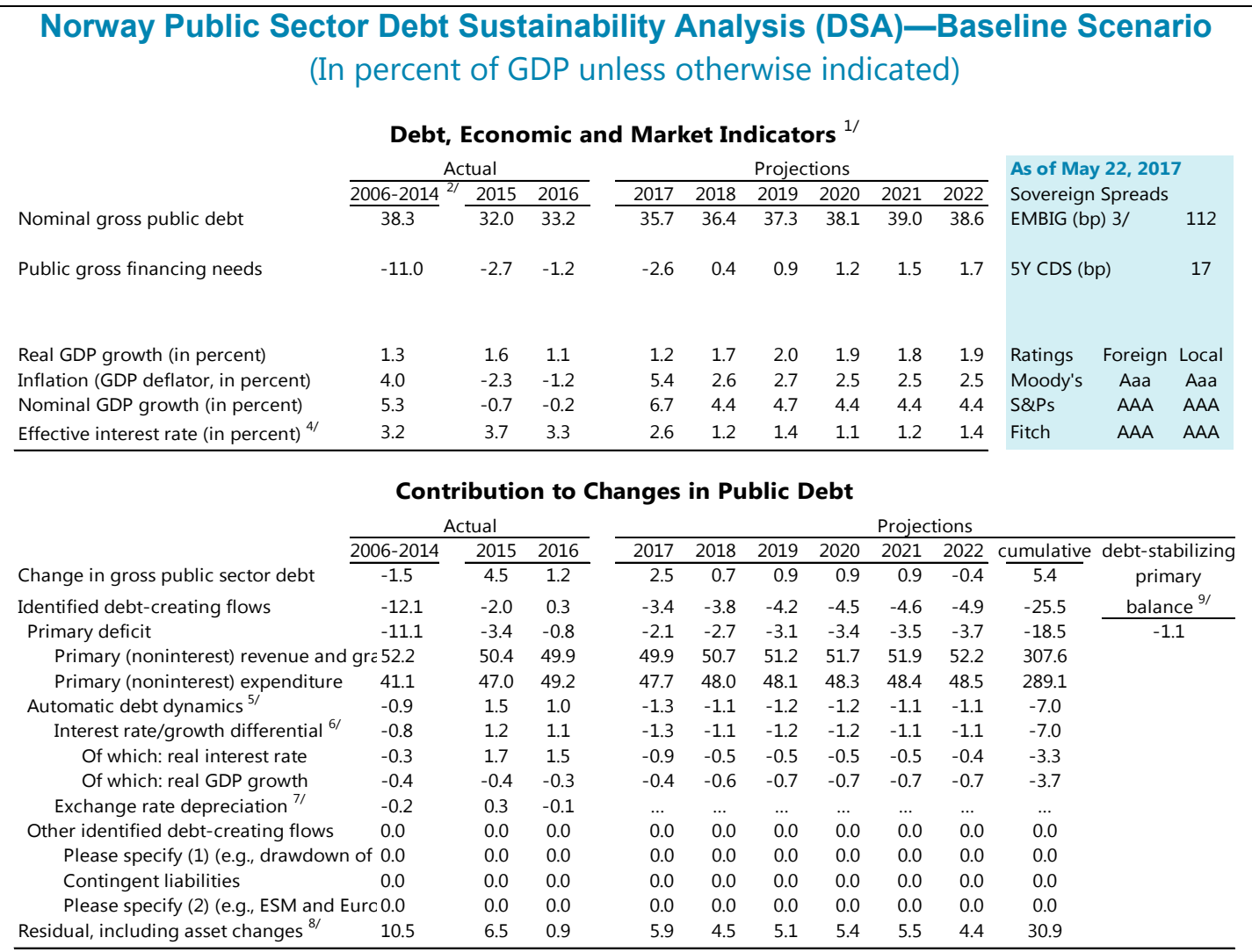
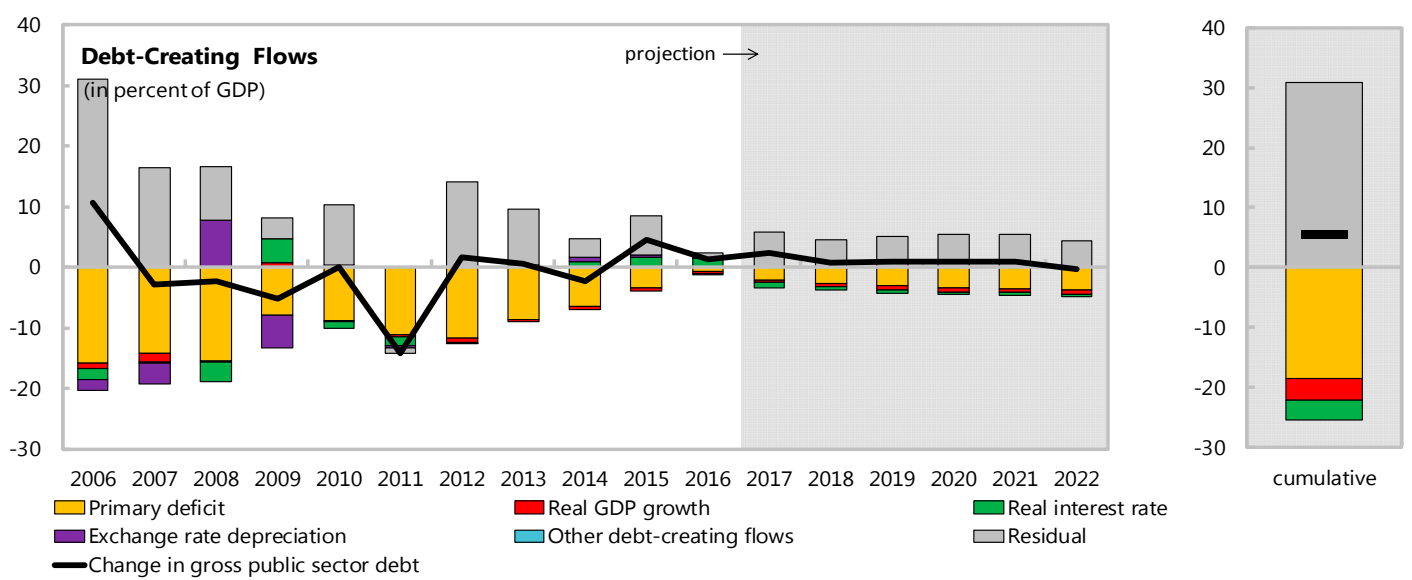

Source: IMF staff.

$1 /$ Public sector is defined as general government.

2/ Based on available data.

3/ Long-term bond spread over German bonds.

4/ Defined as interest payments divided by debt stock (excluding guarantees) at the end of previous year.

5/ Derived as $[(r-\pi(1+g)-g+a e(1+r)] /(1+g+\pi+g \pi))$ times previous period debt ratio, with $r=$ interest rate; $\pi=$ growth rate of GDP deflator; $g=$ real GDP growth rate;

$\mathrm{a}=$ share of foreign-currency denominated debt; and $\mathrm{e}=$ nominal exchange rate depreciation (measured by increase in local currency value of U.S. dollar)

6 / The real interest rate contribution is derived from the numerator in footnote 5 as $r-\pi(1+g)$ and the real growth contribution as $-g$

$7 /$ The exchange rate contribution is derived from the numerator in footnote 5 as ae $(1+r)$.

8/ Includes asset changes and interest revenues (if any). For projections, includes exchange rate changes during the projection period.

9/ Assumes that key variables (real GDP growth, real interest rate, and other identified debt-creating flows) remain at the level of the last projection year. 


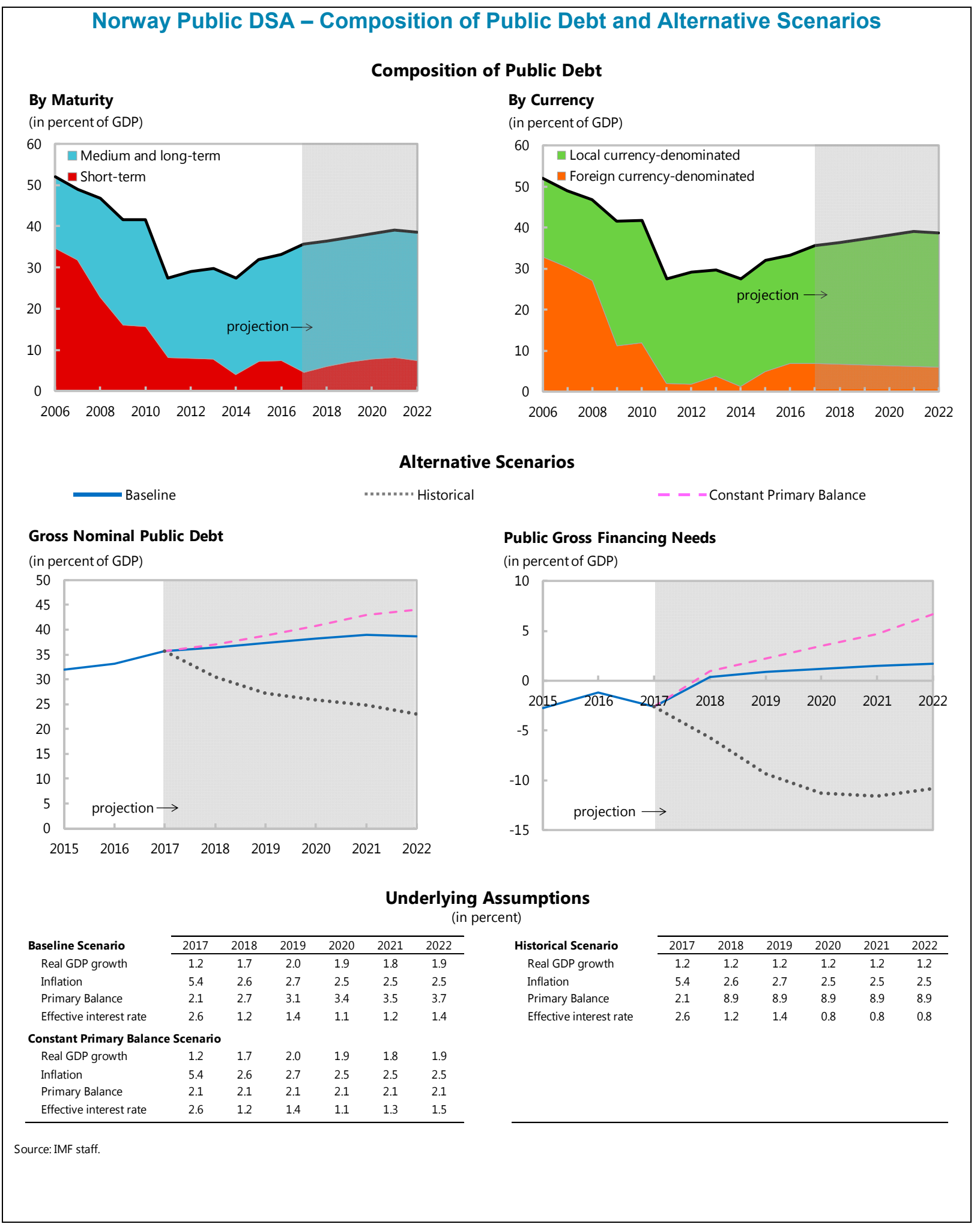




\section{INTERNATIONAL MONETARY FUND}

\section{NORWAY}

STAFF REPORT FOR THE 2017 ARTICLE IV

June 15, 2017

CONSULTATION-INFORMATIONAL ANNEX

$\begin{array}{ll}\text { Prepared By } & \text { European Department } \\ \text { (In consultation with other departments) }\end{array}$

\section{CONTENTS}

FUND RELATIONS

$\underline{2}$

STATISTICAL ISSUES

$\underline{4}$

CInternational Monetary Fund. Not for Redistribution 


\section{FUND RELATIONS}

(As of May 31, 2017)

\section{Membership Status}

Joined: December 27, 1945; Article VIII

\section{General Resources Account}

Quota

$\begin{array}{rr}\text { SDR } & \begin{array}{r}\text { Percent } \\ \text { Millions }\end{array} \\ \text { Quota } \\ 3,754.70 & 100.00\end{array}$

Fund holdings of currency

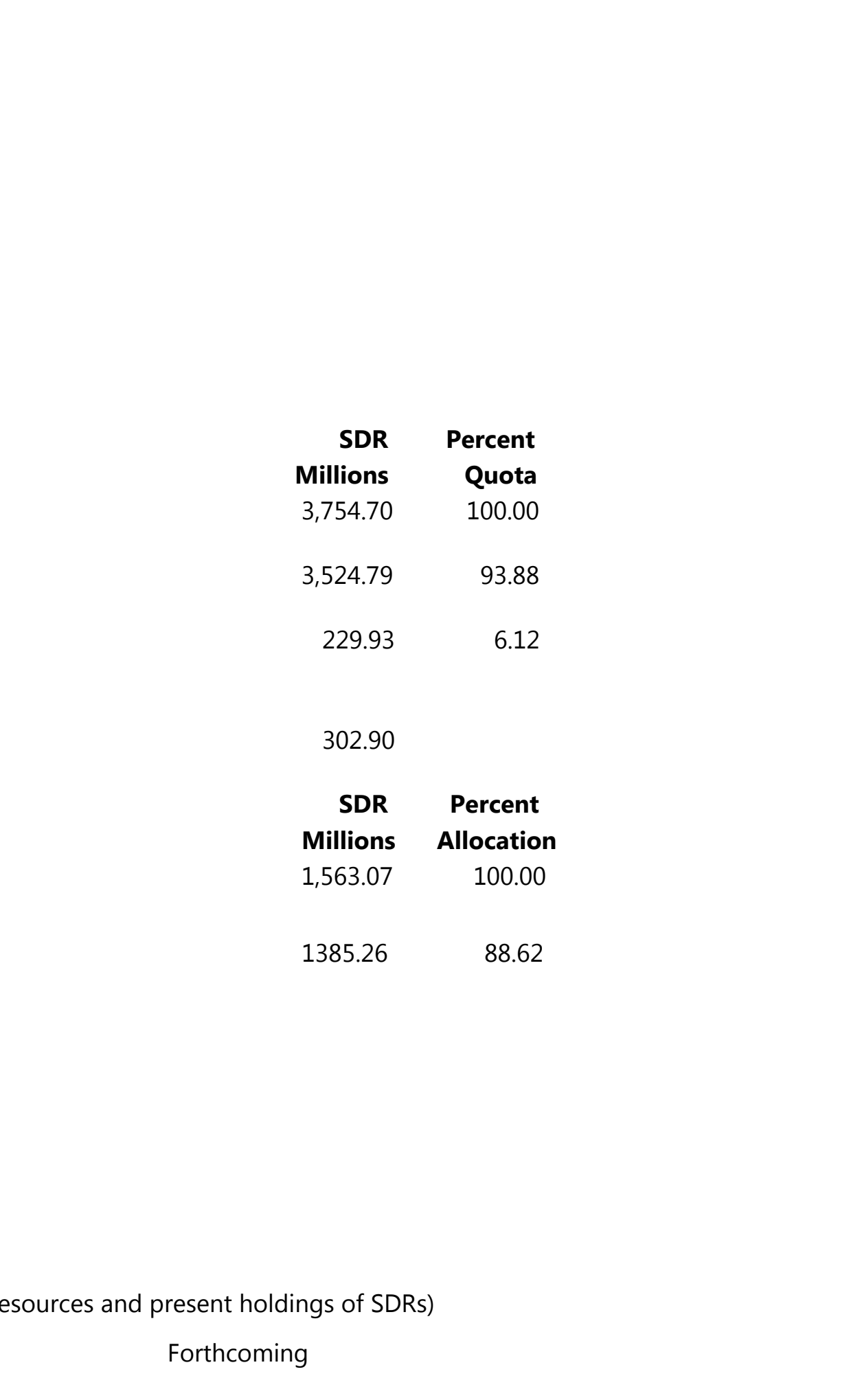

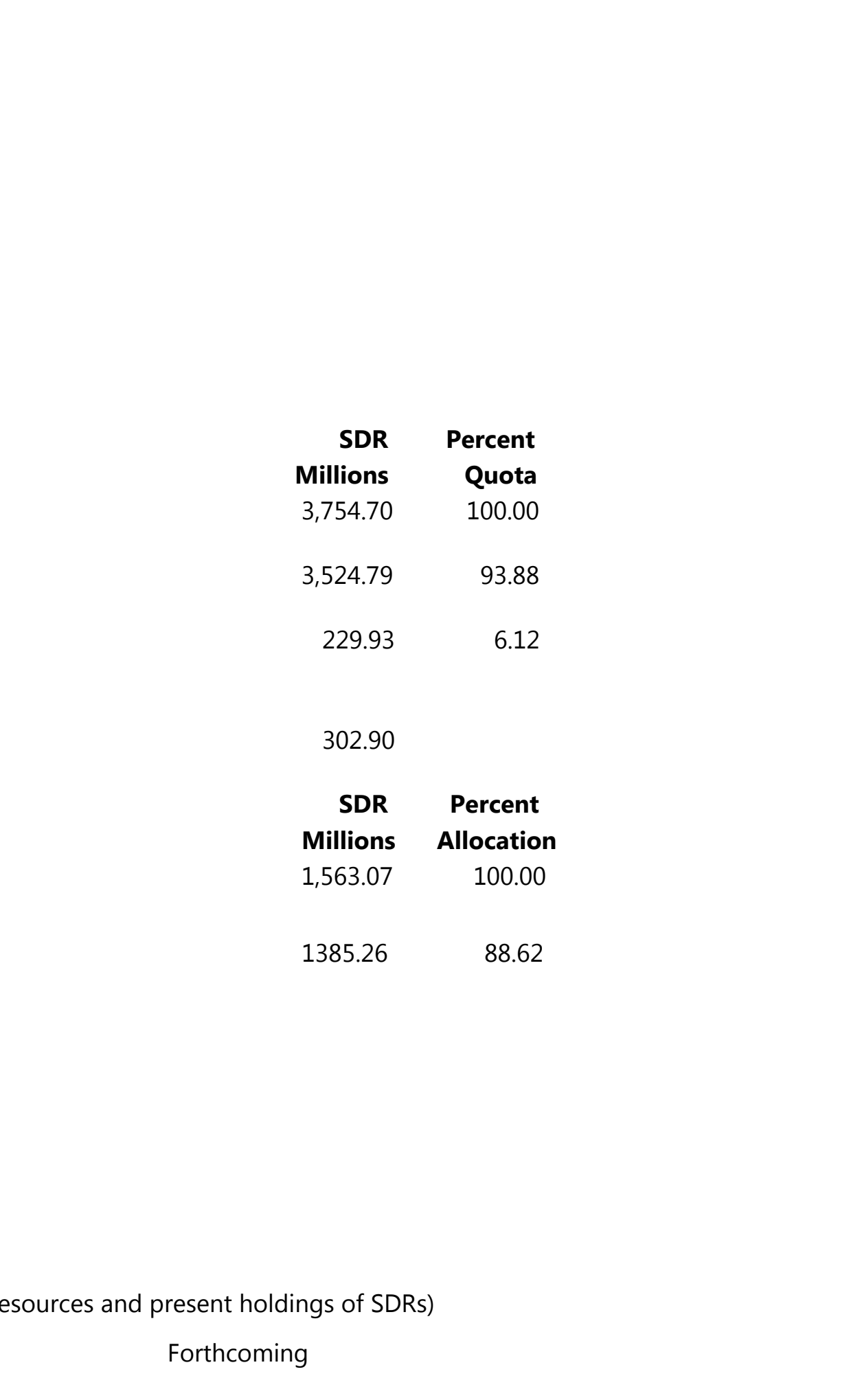

Reserves tranche position

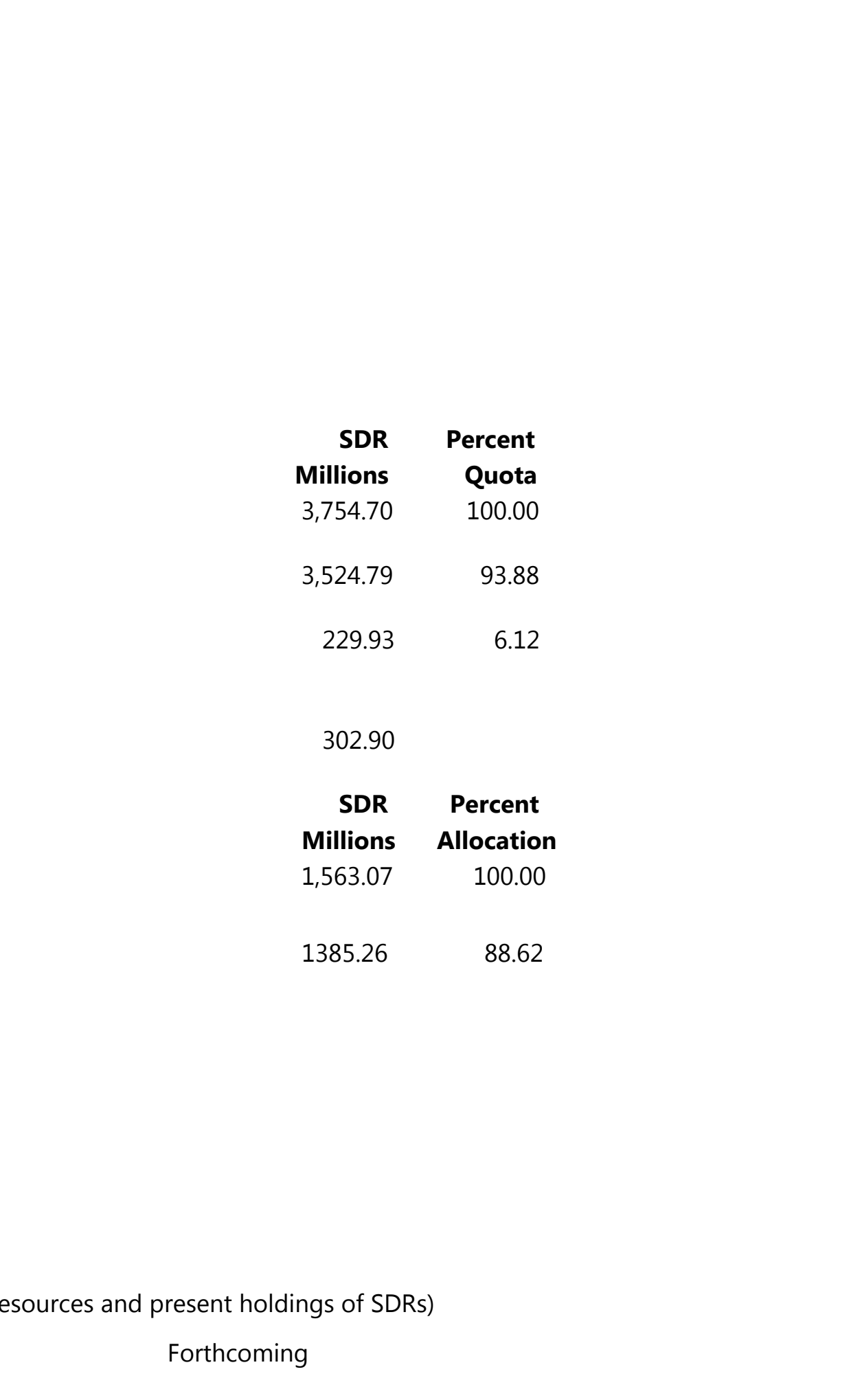

Lending to the Fund

New Arrangements to Borrow

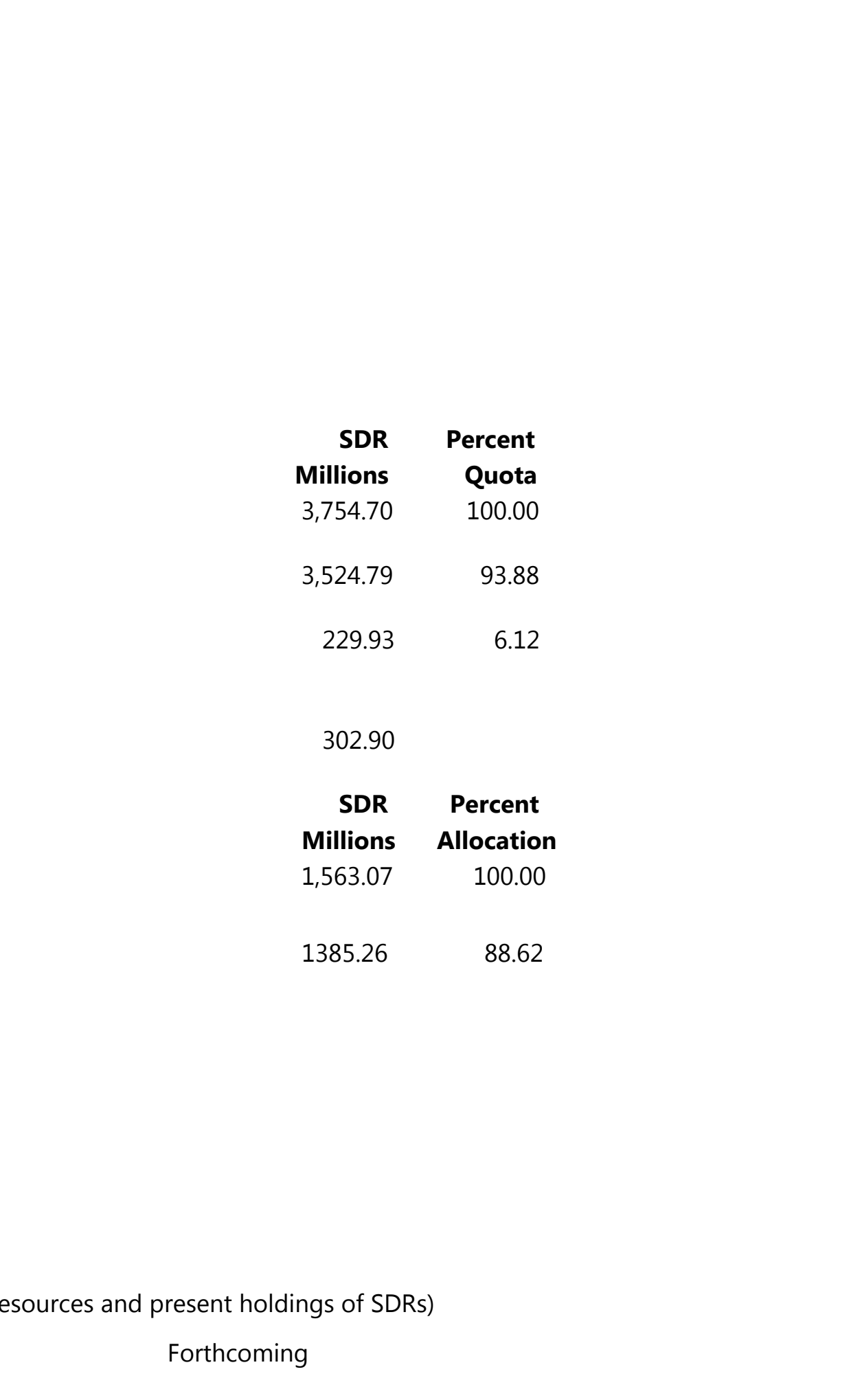

SDR Department

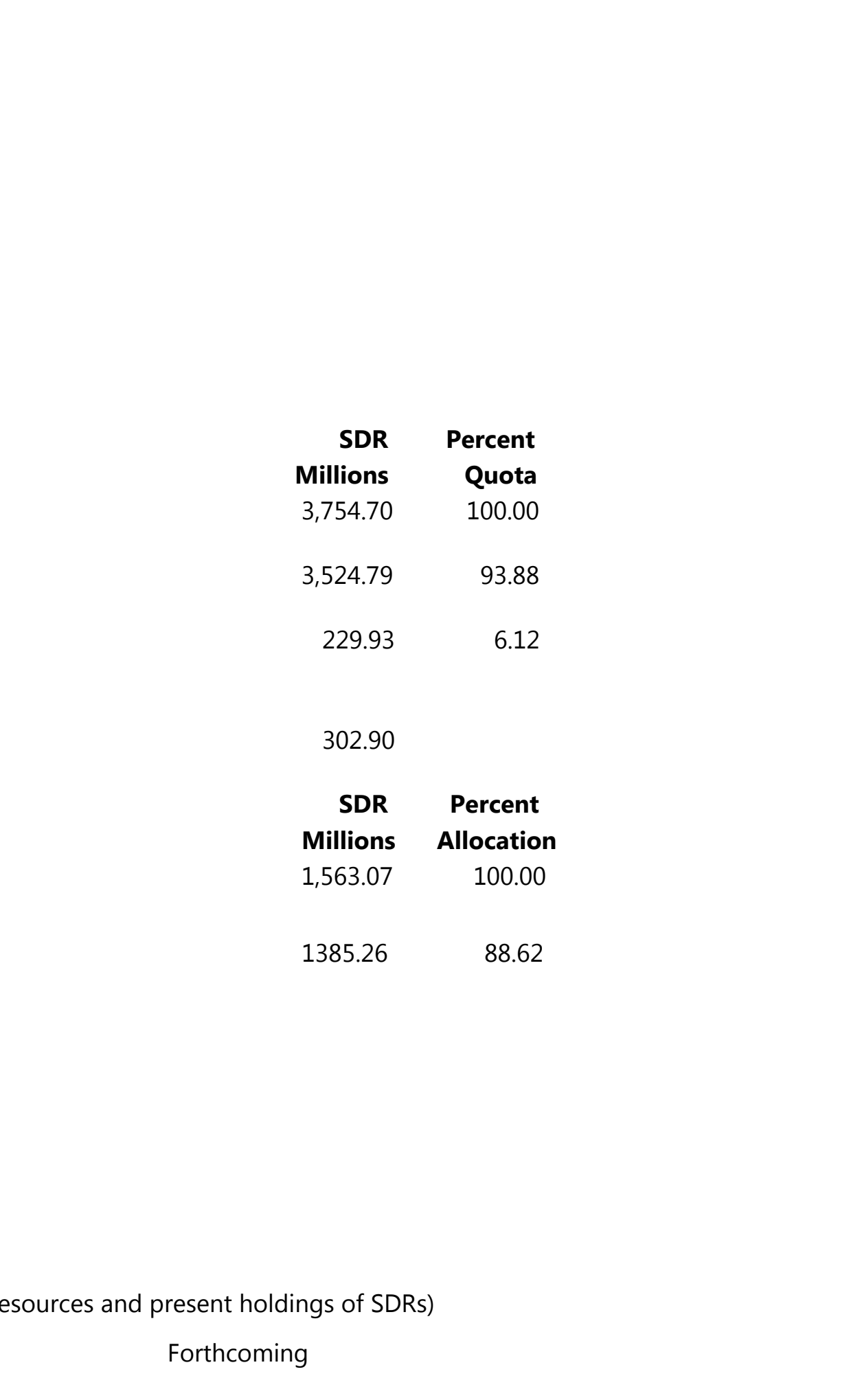

Net cumulative allocations

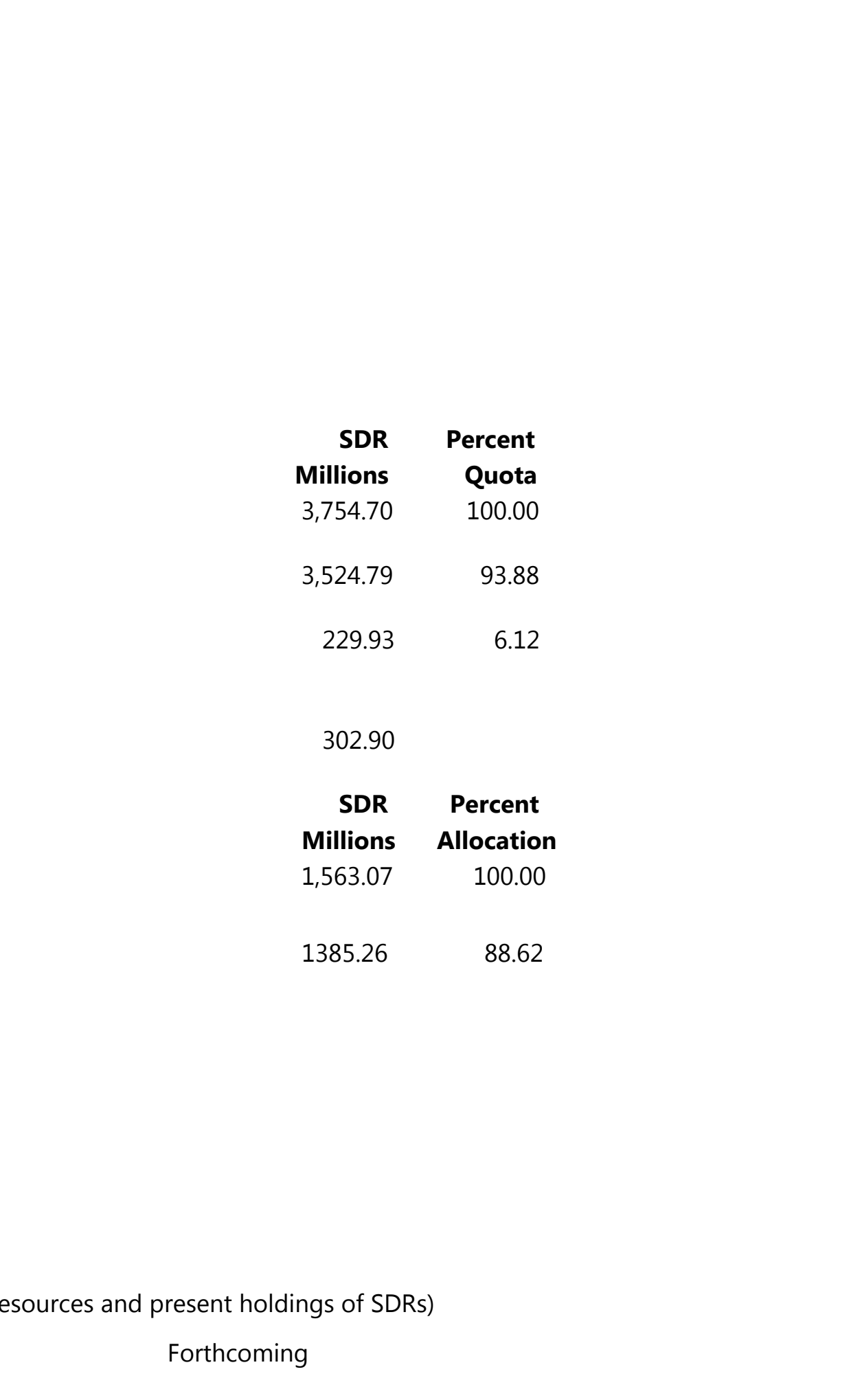

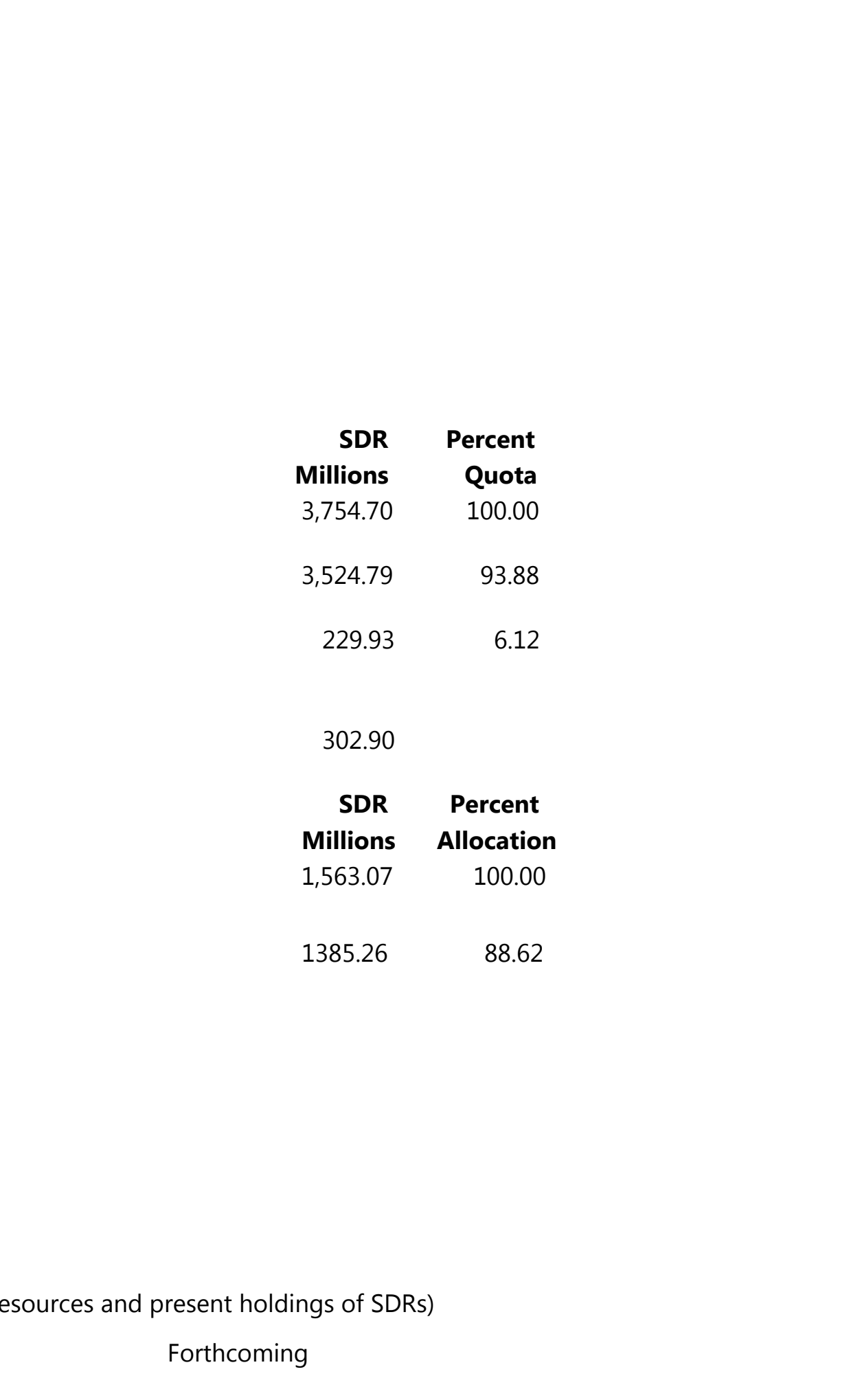

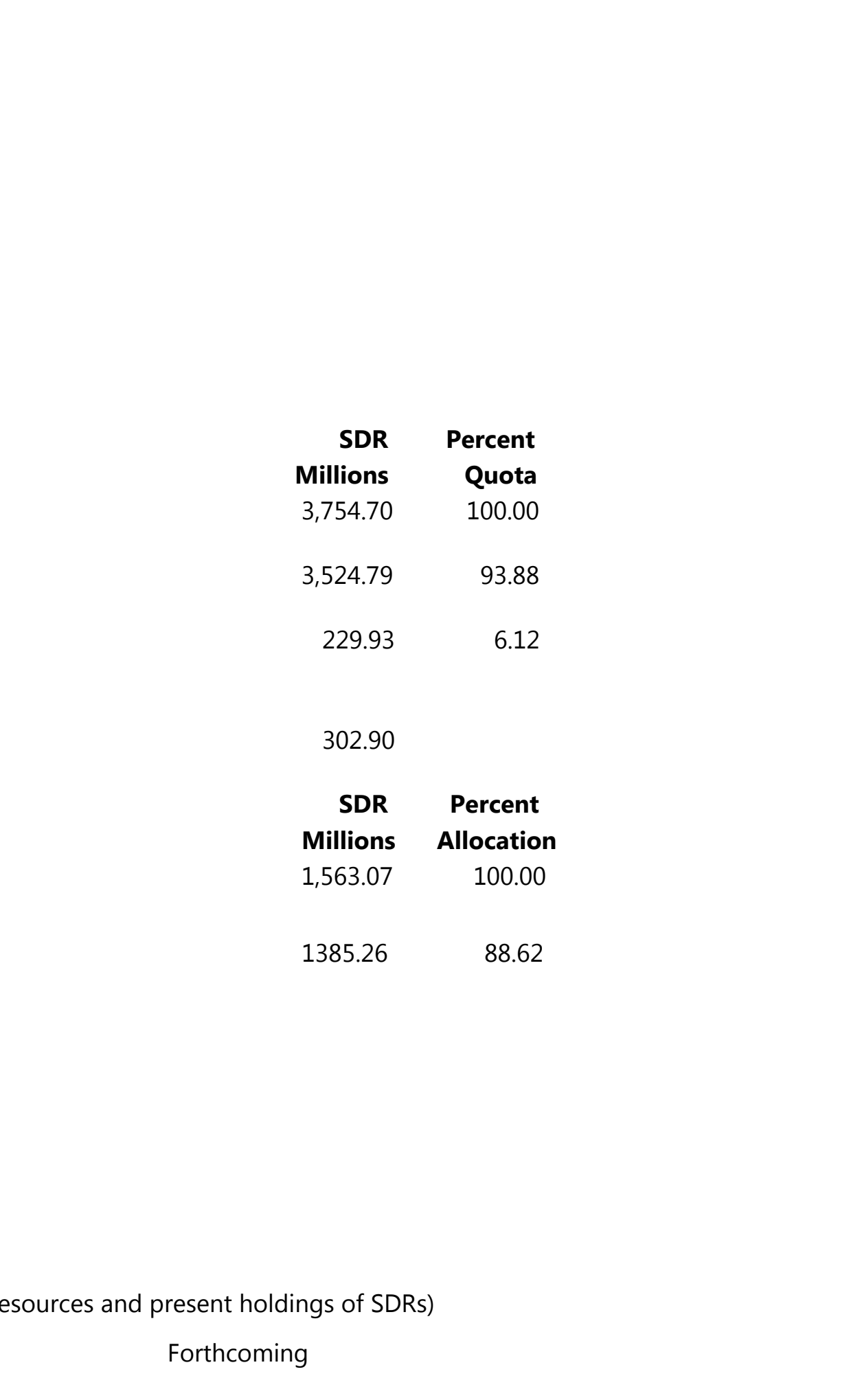

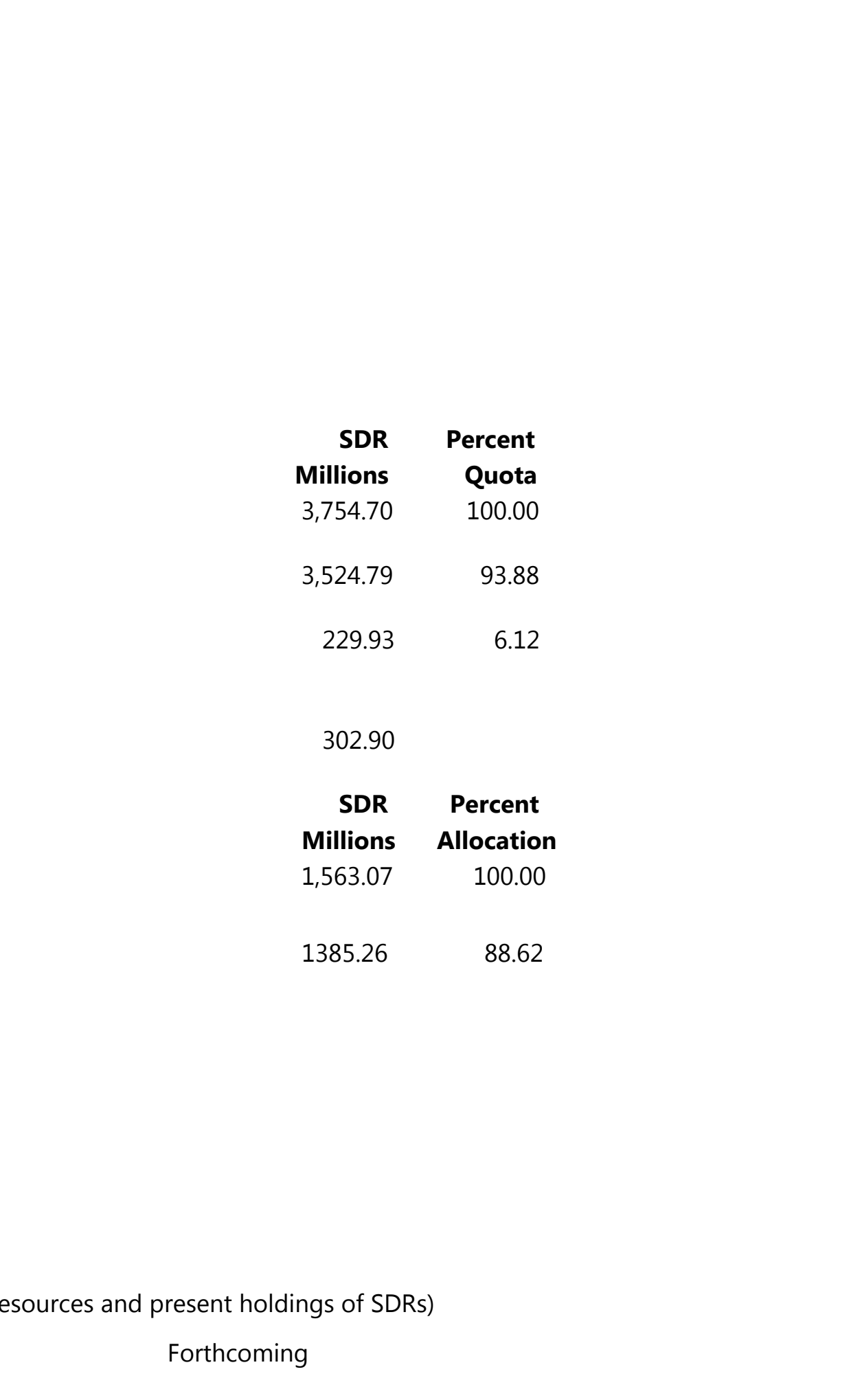

Holdings

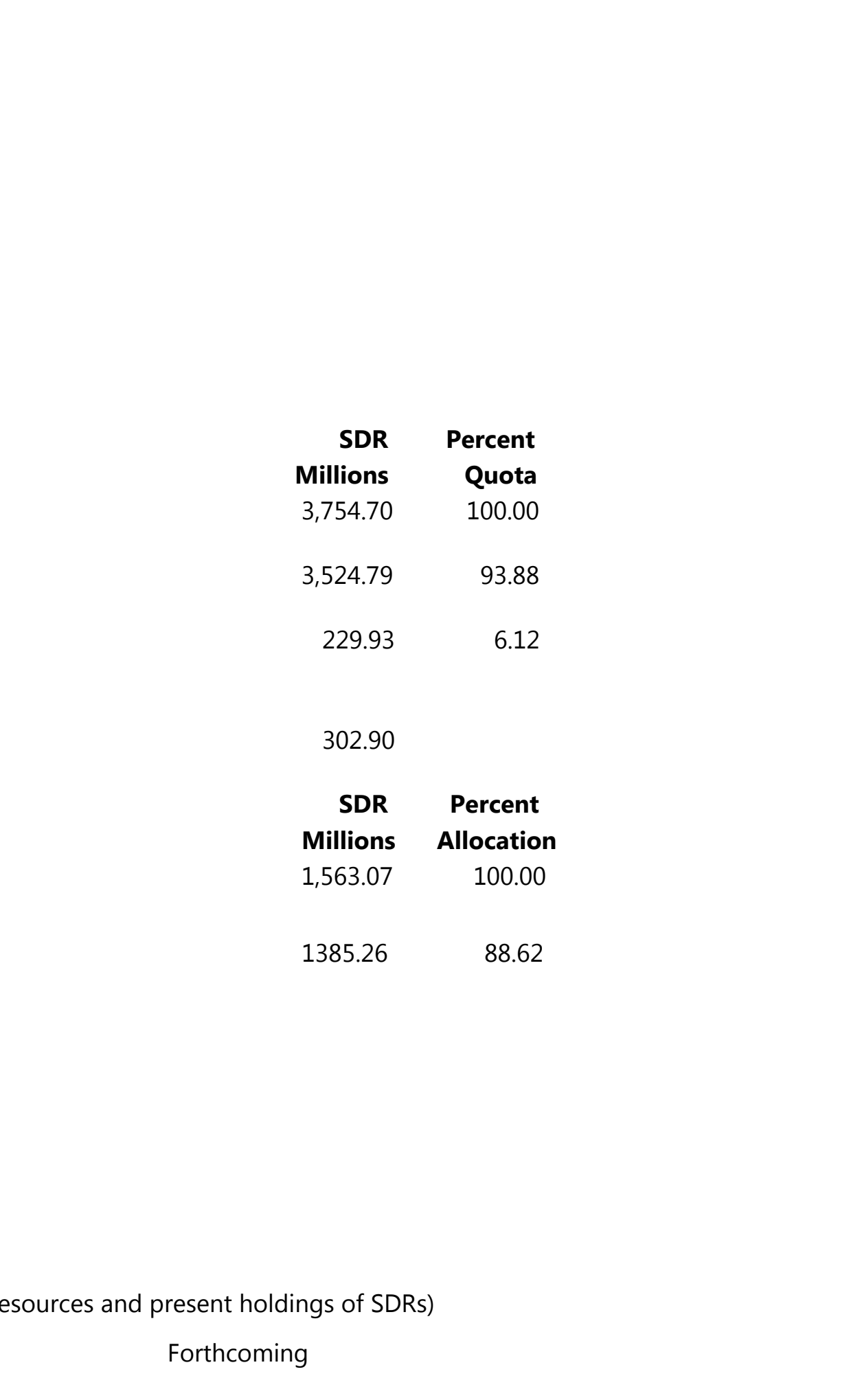

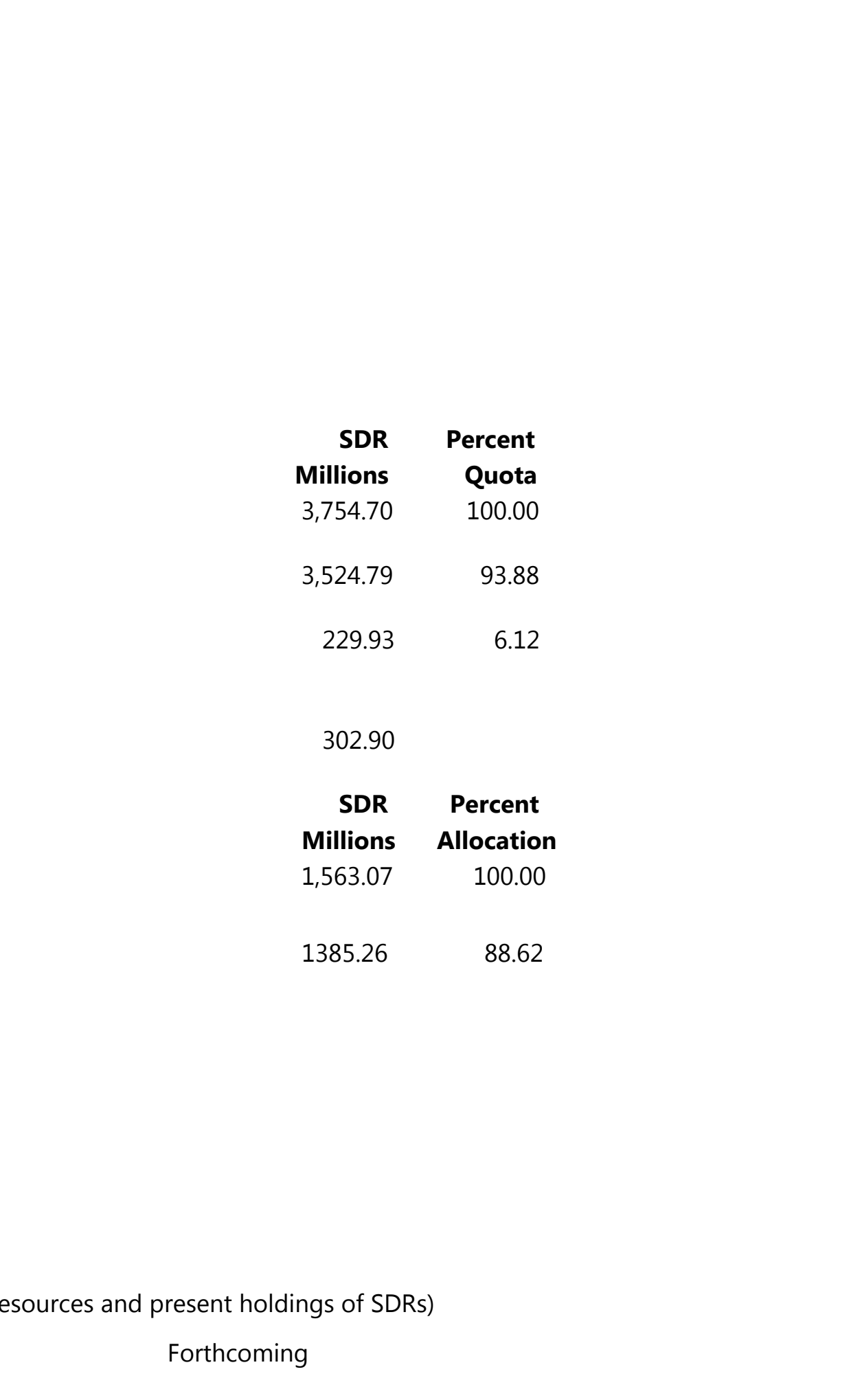

\section{Outstanding Purchases and Loans}

None

\section{Latest Financial Arrangements}

None

Projected Payments to the Fund

(SDR Million; based on existing use of resources and present holdings of SDRs)

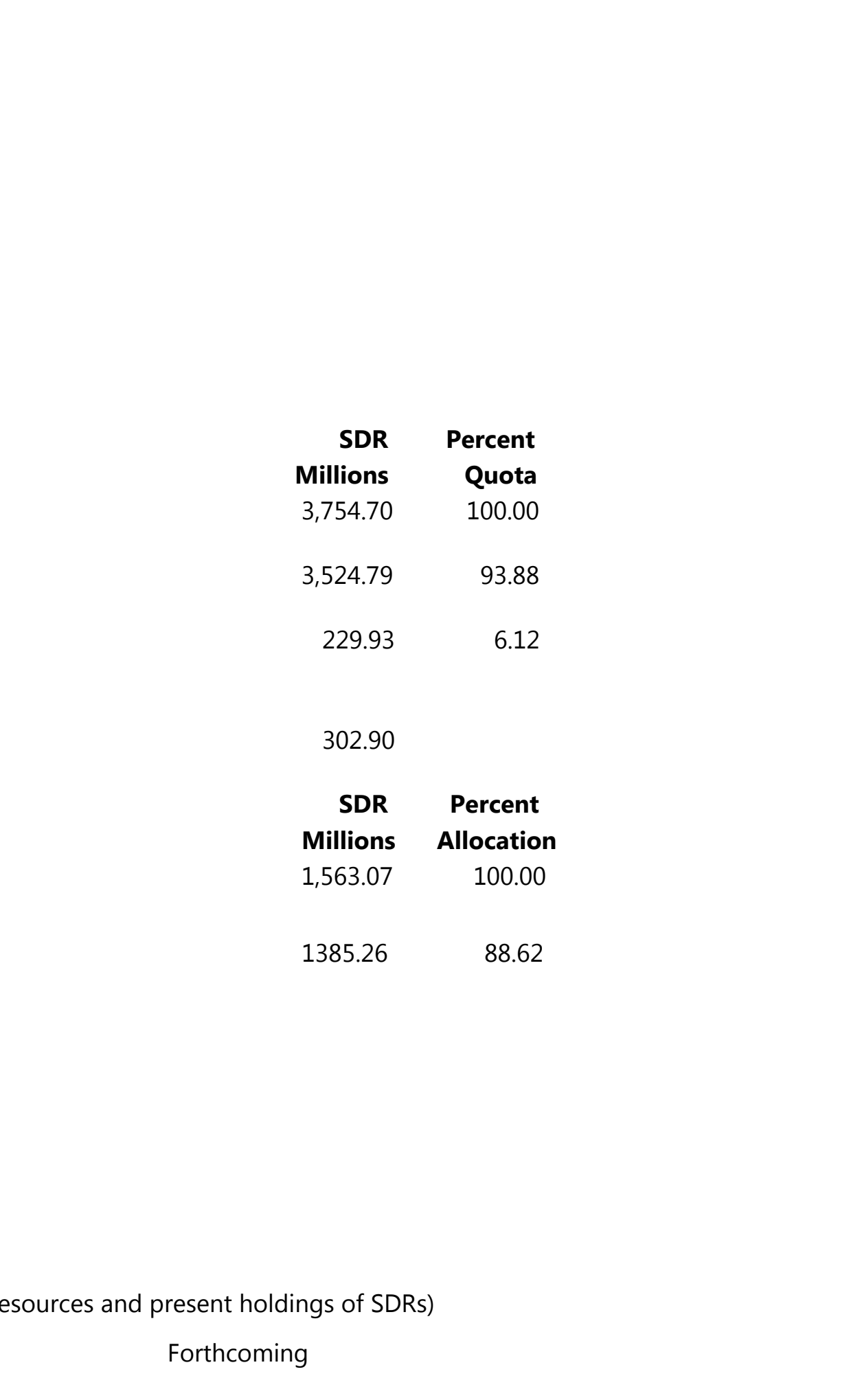

$2017 \quad 2018 \quad 2019 \quad 2020 \quad 2021$

Principal

Charges/Interest

$\begin{array}{lllll}0.49 & 1.02 & 1.02 & 1.02 & 1.02\end{array}$

Total

$\begin{array}{lllll}0.49 & 1.02 & 1.02 & 1.02 & 1.02\end{array}$




\section{Implementation of HIPC Initiative}

Not applicable

Implementation of Multilateral Debt Relief Initiative

Not applicable

Implementation of Catastrophe Containment and Relief (CCR)

Not applicable

\section{Exchange Arrangements}

The de jure and de facto exchange rate arrangements in Norway are classified as freely floating. The exchange system is free of restrictions on the making of payments and transfers for current international transactions other than restrictions notified to the Fund in accordance with Decision No. $144-(52 / 51)$.

\section{Article IV Consultation}

Norway is on the 12-month consultation cycle.

\section{FSAP Participation}

A review under the Financial Sector Assessment Program (FSAP) was completed in 2015.

\section{Technical Assistance}

None

\section{Resident Representative}

None 


\section{STATISTICAL ISSUES}

\section{Statistical Issues Appendix}

(As of May 31, 2017)

\section{Assessment of Data Adequacy for Surveillance}

General: Data provision is adequate for surveillance.

National Accounts: Breakdowns for oil-related parts of the mainland economy and other traditional sectors would be useful, in light of growing needs to better understand the impact of oil and gas activity on the mainland economy. The authorities are making progress in this area.

\section{Data Standards and Quality}

Subscriber to the Fund's Special Data Dissemination Standard (SDDS) since 1996. Uses SDDS flexibility options on the timeliness of the general government operations and central government debt. SDSS metadata are posted on the Dissemination Standard Bulletin Board (DSBB).

Data ROSC completed in 2003 is publicly available. 


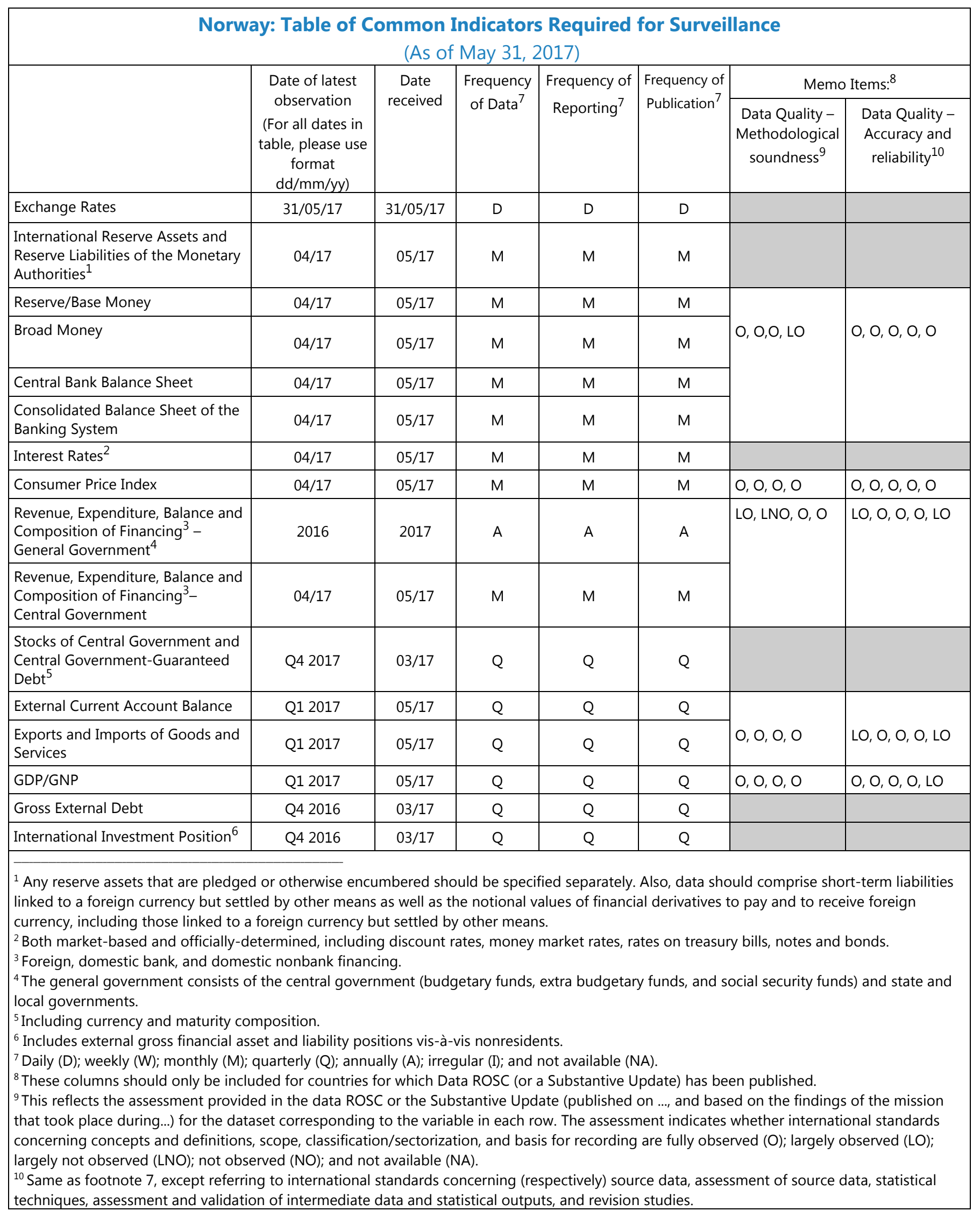

